\title{
SPATIAL AND FUNCTIONAL CHANGES IN BUILT-UP AREAS IN SELECTED SLOVENE RURAL SETTLEMENTS AFTER 1991
}

\section{PROSTORSKE IN FUNKCIJSKE SPREMEMBE POZIDANIH ZEMLJIŠČ V IZBRANIH SLOVENSKIH PODEZELSKIH NASELJIH PO LETU 1991}

Maja Topole, David Bole, Franci Petek, Peter Repolusk

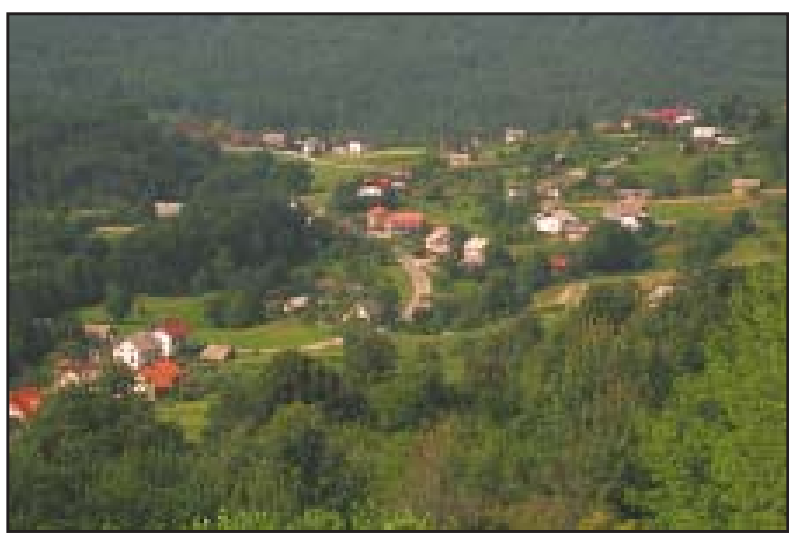

Densely and dispersedly settled areas in our sample of rural settlements are at a ratio of 1 to 3 . In the period from 1992 to 2005 the index of change indicates that in all types of settlements, construction in dispersedly settled areas grew more rapidly than in densely settled areas (photograph: Maja Topole). Razmerje med strnjeno in nestrnjeno poseljenimi površinami v našem vzorcu podeželskih naselij je 1:3. V opazovanem obdobju je bila relativna rast novogradenj najvišja v nestrnjeno poseljenih delih naselij (fotografija: Maja Topole).

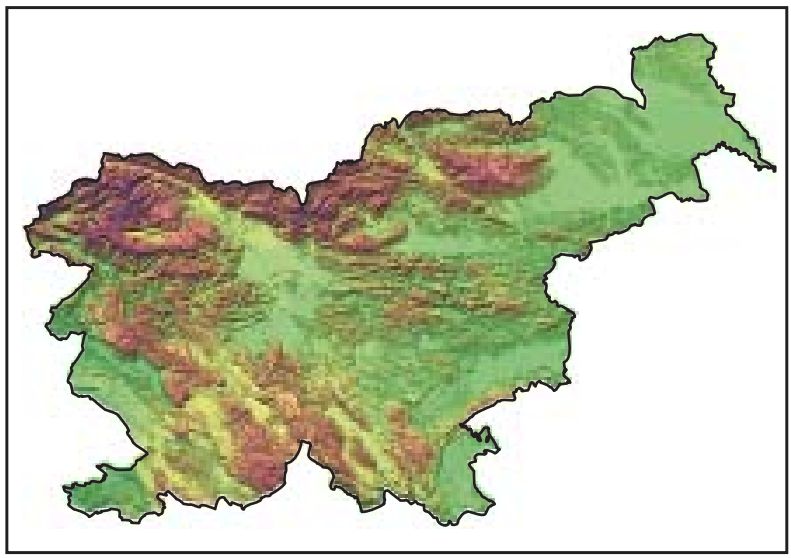




\section{Spatial and functional changes in built-up areas in selected slovene rural settlements after 1991}

UDC: $911.373(497.4)$

COBISS: 1.01

ABSTRACT: We determined changes in the settled areas of rural settlements by means of aerial photos and orthophotos, statistical data, and data obtained through field research. The expert sample comprised 14 rural settlements with 500 to 1100 inhabitants from a variety of Slovene natural and statistical regions which in the past ten-year period have shown positive growth in the number of inhabitants, jobs, and houses. We identified how the following categories changed in settled areas in the period from 1991 to 2005: residential areas, areas with central functions (supply, service, and business), traffic areas and green and other open spaces. Most apparent were differences among the types of settlements. We related land use to the relief and type of settlement, to the geographical location of the settlement, to changes in its structure, and to trends in the number of jobs and extent of commuting.

KEY WORDS: rural geography, Slovene countryside, rural settlements, settlement morphology, land use, jobs, suburbanization

The article was submitted for publication on May 29, 2006.

ADDRESSES:

Maja Topole, Ph. D.

Anton Melik Geographical Institute

Scientific Research Centre of the Slovenian Academy of Sciences and Arts

Gosposka ulica 13, SI - 1000 Ljubljana, Slovenia

E-mail: maja.topole@zrc-sazu.si

David Bole, B. Sc.

Anton Melik Geographical Institute

Scientific Research Centre of the Slovenian Academy of Sciences and Arts

Gosposka ulica 13, SI - 1000 Ljubljana, Slovenia

E-mail: david.bole@zrc-sazu.si

\section{Contents}

1 Introduction

2 Methodology

2.1 Determination of rural settlement and selection of sample

2.2 Data gathered

2.3 Terminology

3 Socioeconomic characteristics of the settlements in the sample

$4 \quad$ Land use and density of jobs

5 Changes in land use in the period from 1992 to 2005

6 Conclusion

7 References
Franci Petek, Ph. D.

Anton Melik Geographical Institute

Scientific Research Centre of the Slovenian Academy of Sciences and Arts

Gosposka ulica 13, SI - 1000 Ljubljana, Slovenia E-mail: franci.petek@zrc-sazu.si

Peter Repolusk, B. Sc.

Anton Melik Geographical Institute

Scientific Research Centre of the Slovenian Academy of Sciences and Arts

Gosposka ulica 13, SI - 1000 Ljubljana, Slovenia

E-mail: peter.repolusk@zrc-sazu.si
191

191

191

195

196

205

211

217

223

225 


\section{Introduction}

The new economic and social policies that were developed after Slovenia's independence in 1991 have had an impact on, among other things, Slovene settlement patterns. Processes which had begun earlier intensified during this period, and differences within the country were exacerbated.

We investigated the extent and nature of these changes in the fifteen years since independence, based on a study of settlements which showed growth in population, housing, and jobs during this period. There are 284 such settlements in Slovenia. We determined the state of these settlements in 1991, or as close as possible to 1991, by means of aerial photos, their state in 2002, a census year, by means of orthophotos, and their state in 2005 by means of studies in the field. Comparisons among individual settlements was enabled by a calculation of the average annual growth in built-up areas. We related these data to the geographic position of the settlement, the number of inhabitants, the number of employed and the number of available jobs, and the commuting patterns of residents.

In order to obtain quantitative data and identify patterns and differences in the spatial and functional changes of rural settlements, we carried out field surveys of the settled areas of settlements. We distinguished among areas used for housing, areas with supply, service and business or so-called central functions, areas used for traffic, and green and other areas without any buildings. The basis of this article is the report by Topole et al. (2005). The focus of this article is Slovene rural settlements; processes in urban and suburban settlements were studied at the same time by a different group of experts (Krevs 2005).

\section{Methodology}

\subsection{Determination of rural settlement and selection of sample}

Our first task was to select an appropriate sample of Slovene rural settlements. Since the available funding for the research did not allow for a sufficiently large statistical sample of settlements that would be manageable in the field, we were compelled to select a so-called expert sample of settlements which would be as representative as possible and would indicate the various possible paths of development of settled areas with respect to the natural conditions and types of settlements.

A formal and fully elaborated definition for the expression rural settlement does not exist in Slovenia. The Statistical Office of the Republic of Slovenia has only two classifications of settlement: urban and non-urban. According to this classification, all non-urban settlements are considered rural settlements.

The Statistical Yearbook of the Republic of Slovenia for 2005 classifies 156 Slovene settlements as urban settlements and settlements of urban regions. 967,496 people, or $49.5 \%$ of the total population of Slovenia and $48.5 \%$ of the economically active population live in these settlements. In order to be classified as an urban settlement a place must meet at least one of the following criteria:

- have 3000 or more inhabitants (formal criterion) or

- have 2000 to 2999 inhabitants and have more jobs than the number of the economically active residents of the settlement (formal, functional criterion) or

- be a municipal seat and have at least 1400 inhabitants and a surplus of jobs or be a municipal seat and have at least 2000 inhabitants (formal, functional criterion) or

- belong to an urban region; have a lower number of inhabitants but grow into a single functional whole with an urban settlement which has more than 5000 inhabitants and contiguous building. Commuting is considered to be an inclusionary criterion of functional connectedness, while a certain share of farm households in a suburban settlement is an exclusionary criterion (physiognomic-morphological, functional criterion).

Non-urban settlements are all settlements which do not meet the statistical definition of urban settlements and settlements in urban regions; these are the ones which come under consideration for our study. In Slovenia as of 1 January 2005, 5842, or $97 \%$ of settlements were non-urban, and a little over half of the population of Slovenia live in them $(985,809$, or $50.5 \%) .51 .5 \%$ of the total economically active population live in these settlements. We selected a sample from among these that met the following additional conditions: - the settlement was relatively large, with a 2002 population of between 500 and 1100 people (average 900), - the number of inhabitants and the number of houses grew during the period from 1991 to 2002, 
Table 1: Basic data on the settlements selected

\begin{tabular}{|c|c|c|c|c|c|c|c|c|c|c|c|c|c|}
\hline & $\begin{array}{l}\text { name of } \\
\text { settlement }\end{array}$ & $\begin{array}{l}\text { area of } \\
\text { settlement } \\
\text { in ha }\end{array}$ & $\begin{array}{l}\text { farm } \\
\text { population } \\
\text { in } 1991 \text { in \% }\end{array}$ & & population & & $\begin{array}{l}\text { index of } \\
\text { population growth } \\
2002 / 1991\end{array}$ & $\begin{array}{l}\text { natural } \\
\text { region }\end{array}$ & $\begin{array}{l}\text { landscape type } \\
\text { (Urbanc 2002) }\end{array}$ & $\begin{array}{l}\text { munici- } \\
\text { pality }\end{array}$ & $\begin{array}{l}\text { statistical } \\
\text { region }\end{array}$ & \multicolumn{2}{|c|}{$\begin{array}{ll}\text { distance } & \text { type of } \\
\text { from nearest } & \text { settlement } \\
\text { town in } \mathrm{km} & \end{array}$} \\
\hline & & & & $\begin{array}{l}1991 \text { old } \\
\text { method }\end{array}$ & $\begin{array}{l}1991 \text { new } \\
\text { method }\end{array}$ & 2002 & & & & & & & \\
\hline 1 & $\begin{array}{l}\text { Spodnja Besnica } \\
\text { and Zgornja } \\
\text { Besnica }\end{array}$ & 1878.7605 & 5.9 & 1323 & 1316 & 1517 & 115.3 & $\begin{array}{l}\text { edge of } \\
\text { the Škofja } \\
\text { Loka hills }\end{array}$ & $\begin{array}{c}\text { alpine } \\
\text { hills }\end{array}$ & Kranj & Gorenjska & $\mathrm{n}$ & $\begin{array}{l}\text { nucleated core, } \\
\text { dispersed outer } \\
\text { areas }\end{array}$ \\
\hline 2 & Ihan & 155.9065 & 9.5 & 640 & 634 & 701 & 110.6 & $\begin{array}{l}\text { Kamniška } \\
\text { Bistrica plain }\end{array}$ & $\begin{array}{l}\text { alpine } \\
\text { lowland }\end{array}$ & Domžale & $\begin{array}{l}\text { Osrednje- } \\
\text { slovenska }\end{array}$ & $\mathrm{n}$ & $\begin{array}{l}\text { nucleated core, } \\
\text { dispersed outer } \\
\text { areas }\end{array}$ \\
\hline 3 & Brdinje & 899.6086 & 7.1 & 539 & 538 & 628 & 116.7 & $\begin{array}{l}\text { Western } \\
\text { Pohorsko } \\
\text { Podravje }\end{array}$ & $\begin{array}{c}\text { alpine } \\
\text { hills }\end{array}$ & $\begin{array}{l}\text { Ravne } \\
\text { na Kor }\end{array}$ & Koroška & ro & $\begin{array}{l}\text { roadside, hamlets } \\
\text { and isolated } \\
\text { farms }\end{array}$ \\
\hline 4 & Lipovci & 705.6035 & 21.0 & 1027 & 995 & 1047 & 105.2 & $\begin{array}{l}\text { Mura River } \\
\text { plain }\end{array}$ & $\begin{array}{l}\text { Pannonian } \\
\text { plain }\end{array}$ & Beltinci & Pomurska & 1.5 & nucleated \\
\hline 5 & $\begin{array}{l}\text { Krčevina pri } \\
\text { Vurbergu }\end{array}$ & 969.7857 & 19.1 & 646 & 607 & 811 & 133.6 & $\begin{array}{l}\text { Slovenske } \\
\text { gorice }\end{array}$ & $\begin{array}{l}\text { Pannonian } \\
\text { hills }\end{array}$ & Ptuj & Podravska & d & $\begin{array}{l}\text { dispersed, } \\
\text { partially roadside }\end{array}$ \\
\hline 6 & Uršna Sela & 1200.3761 & 10.4 & 546 & 541 & 588 & 108.7 & $\begin{array}{l}\text { Novo mesto } \\
\text { region }\end{array}$ & $\begin{array}{l}\text { Dinaric } \\
\text { valley } \\
\text { system }\end{array}$ & $\begin{array}{l}\text { Novo } \\
\text { mesto }\end{array}$ & $\begin{array}{l}\text { Jugo- } \\
\text { vzhodna } \\
\text { Slovenija }\end{array}$ & di & $\begin{array}{l}\text { dispersed, } \\
\text { partially nucleated } \\
\text { and roadside }\end{array}$ \\
\hline 7 & Žužemberk & 776.5692 & 6.8 & 991 & 979 & 1085 & 110.8 & Suha krajina & $\begin{array}{l}\text { Dinaric } \\
\text { plain }\end{array}$ & Žužemberk & $\begin{array}{l}\text { Jugo- } \\
\text { vzhodna } \\
\text { Slovenija }\end{array}$ & 17.5 & $\begin{array}{l}\text { nucleated core, } \\
\text { dispersed outer } \\
\text { areas }\end{array}$ \\
\hline 8 & Velike Lašče & 597.3676 & 6.9 & 561 & 551 & 639 & 116.0 & $\begin{array}{l}\text { Velike } \\
\text { Lašče } \\
\text { region }\end{array}$ & $\begin{array}{l}\text { Dinaric } \\
\text { valley } \\
\text { system }\end{array}$ & $\begin{array}{l}\text { Velike } \\
\text { Lašče }\end{array}$ & $\begin{array}{l}\text { Osrednje- } \\
\text { slovenska }\end{array}$ & $\mathrm{n}$ & $\begin{array}{l}\text { nucleated core, } \\
\text { dispersed outer } \\
\text { areas }\end{array}$ \\
\hline 9 & $\begin{array}{l}\text { Lož and Stari } \\
\text { trg pri Ložu }\end{array}$ & 899.6086 & 3.7 & 1315 & 1307 & 1377 & 105.4 & $\begin{array}{l}\text { Notranjska } \\
\text { valley } \\
\text { system }\end{array}$ & $\begin{array}{l}\text { Dinaric } \\
\text { valley } \\
\text { system }\end{array}$ & $\begin{array}{l}\text { Loška } \\
\text { dolina }\end{array}$ & Notranjska & $\mathrm{n}$ & $\begin{array}{l}\text { nucleated core, } \\
\text { dispersed outer } \\
\text { areas }\end{array}$ \\
\hline 10 & Parecag & 982.2554 & 6.9 & 760 & 751 & 910 & 121.2 & Koper Littoral & $\begin{array}{l}\text { Mediterranean } \\
\text { hills }\end{array}$ & Piran & $\begin{array}{l}\text { Obalno- } \\
\text { kraška }\end{array}$ & $\mathrm{n}$ & $\begin{array}{l}\text { nucleated core, } \\
\text { dispersed outer } \\
\text { areas }\end{array}$ \\
\hline 11 & Križ and Šepulje & 598.7303 & 11.2 & 432 & 438 & 580 & 132.4 & Karst & $\begin{array}{r}\text { Mediterranean } \\
\text { Karst plateau }\end{array}$ & Sežana & $\begin{array}{l}\text { Obalno- } \\
\text { kraška }\end{array}$ & 5 & nucleated \\
\hline$\sum$ & total & 9664.5720 & 9.4 & 8780 & 8657 & 9883 & 114.0 & 1 & I & 1 & / & 7.5 & 1 \\
\hline
\end{tabular}




\section{Surveyable map: Slovene Settlements Represented in Expert Sample}

Pregledni zemljevid - V ekspertnem vzorcu zastopana slovenska naselja

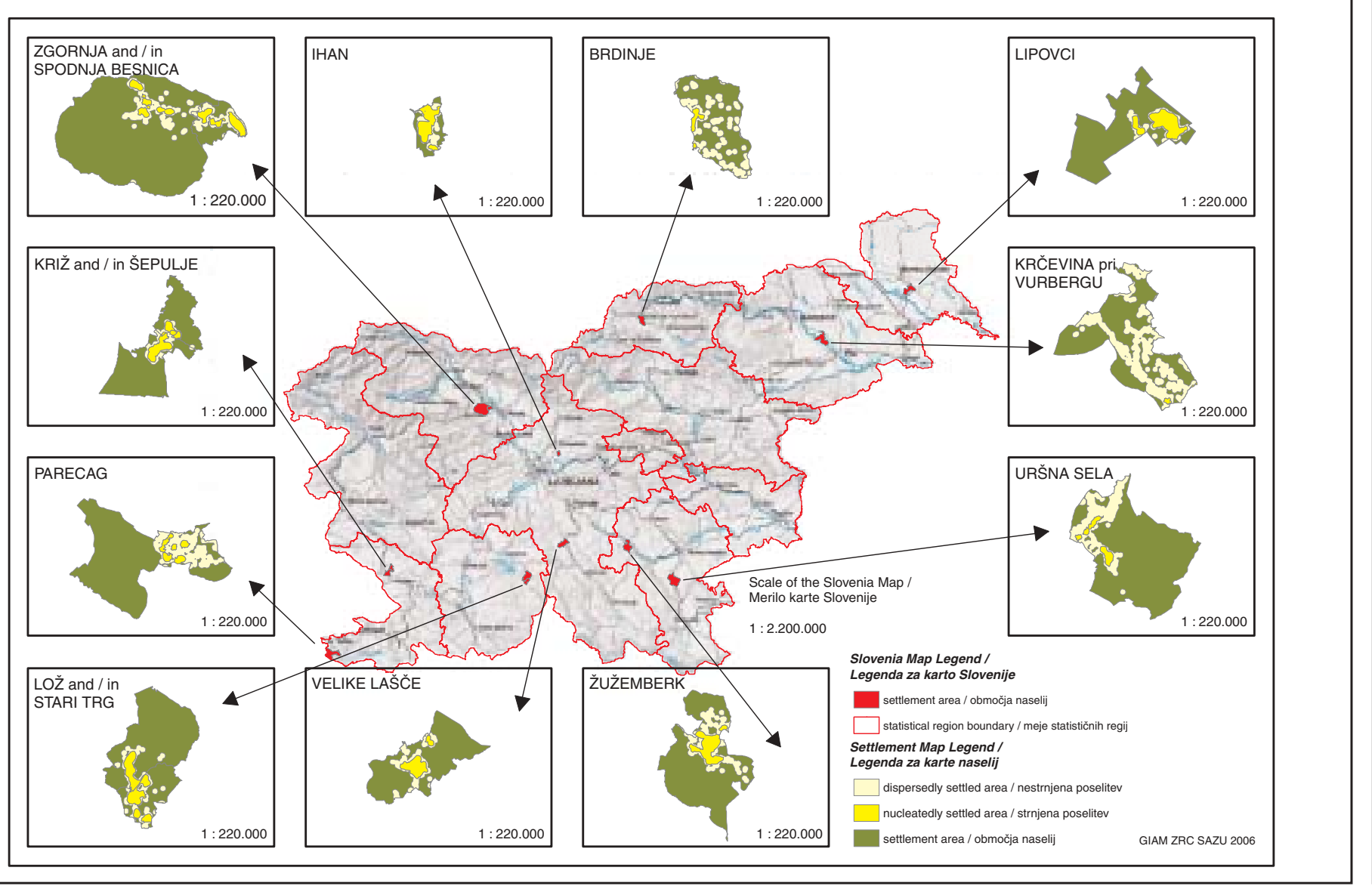


- based on data from 1991, the settlement had a relatively large share of residents engaged in agriculture, from 3.7\% (Lož and Stari trg) to 21\% (Lipovci) and a large share of contiguous agricultural and forested areas,

- municipal centers were included rarely, and only if they had fewer than 1400 inhabitants (Žužemberk and Velike Lašče, Stari trg pri Ložu). In this way rural centers were included that were not in the vicinity of large agglomerations,

- the settlements lie in a variety of Slovene natural regions (alpine hills, alpine lowland, Pannonian plain, Dinaric valley system, Dinaric plain, Mediterranean hills, Mediterranean karst plateau) and thus belong to different morphological types (nucleated as well as dispersed, or clustered and roadside as well as those in the form of hamlets and isolated farmsteads),

- the settlements are located in different Slovene statistical regions (Gorenjska, Osrednjeslovenska, Koroška, Pomurska, Podravska, Jugovzhodna Slovenija, Notranjska, Obalnokraška).

A basic feature of changes affecting settlements in Slovenia is the growth of urban and the decline of non-urban settlements. Between 1991 and 2002 the number of registered housing units (RHU) increased most in the settlement of Ljubljana (+3032), followed by other major urban settlements (Maribor, Novo mesto, Kranj, Koper, Celje). The number of RHUs did not increase in 1291 settlements, while for 958 settlements the number increased by more than 10 units.

During the same period, according to census data, the population increased in 3338 settlements, remained the same in 236 settlements, and decreased in 2318 settlements. Settlements showing the most growth were those located in the immediate vicinity of major cities, for example: Logatec, Ig, Trzin, Vrhnika, Grosuplje (vicinity of Ljubljana), Sv. Anton (Koper). Similarly, some settlements in the vicinity of smaller urban centers also increased in size, for example Kotlje, near Slovenj Gradec, or Lucija, near Piran. The population dropped most sharply in highly urban settlements such as Maribor, Jesenice, Ljubljana, and Celje and in markedly rural settlements far from urban centers.

Our sample comprised 11 settlement units, or 14 settlements. In addition to eight separate settlements (Ihan, Brdinje, Lipovci, Krčevina pri Vurbergu, Uršna sela, Žužemberk, Velike Lašče and Parecag) we studied three pairs of settlements: Spodnja (Lower) and Zgornja (Upper) Besnica, Lož and Stari trg pri Ložu, and Križ and Šepulje; these are morphologically and demographically homogeneous units. The settlements vary in elevation - from $0 \mathrm{~m}$ or an average of $20 \mathrm{~m}$ in the case of Parecag to $685 \mathrm{~m}$ or an average of $450 \mathrm{~m}$ in the case of Brdinje. They are distributed among regions in all three major Slovene climatic types: temperate continental, submediterranean, and montane. Their distance from the nearest urban settlement ranges from $1.5 \mathrm{~km}$ to $17.5 \mathrm{~km}$, averaging $7.5 \mathrm{~km}$, and from the nearest major highway from $1 \mathrm{~km}$

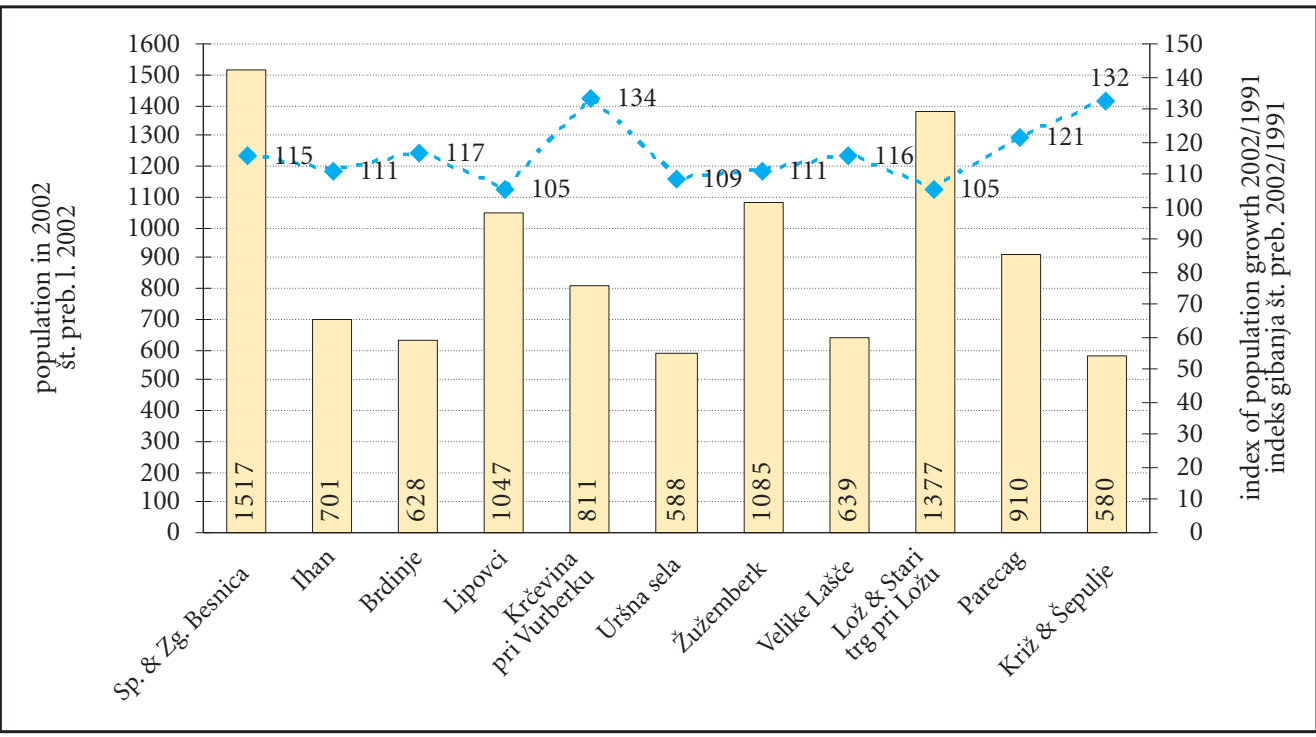

Figure 2: Population in 2002 and index of population growth 2002/1991. 
to $29.8 \mathrm{~km}$, or an average of $10.2 \mathrm{~km}$. The settlements included in the expert sample were also not identified as urban settlements according to the Law on local self-government. Basic data on their population and spatial features are shown in Figure 1 and Table 1.

\subsection{Data gathered}

We determined the use of settled areas within the settlement on two levels. On one level, within the settlement we distinguished buildings along with their accompanying grounds, traffic areas, green space (parks, gardens, roadside green belts and similar), forest, water areas, and other types of land without buildings. We then separately determined the functions of buildings as to whether they were residential, non-residential, or mixed residential-non-residential.

Changes in the extent of the settled area (expansion and concentration) were determined from aerial photos (1990-1992), from the first generation of orthophotos (1997-2000) and from field work (2005). The method of data entry was digitalization or vectorization of categories of settled area based on orthophotos using ARC GIS instruments. We added corrections to the vector photos for the situation before and after the emergence of orthophotos. We identified an area as green or open space only if it measured at least $17 \mathrm{~m}$ in length and width and allowed for the construction of a small separate building; otherwise we combined the surroundings of the building (lawn, garden, courtyard) and the building itself in one built-up area.

On a thematic map we showed the state of the built-up area for each settlement based on three chronological landmarks:

- the initial year (which is not always the same for each settlement; only data which were as close as possible to the census year 1991 were considered - see Table 2)

- at the time of orthophotography or aerial photography (around 1997 - but the year is also not always the same - see Table 2) and

- 2005, when we conducted an inspection of the settlement in the field.

In this way we determined:

- the extent of built-up area before 1991,

- the extent of the area built up between 1991 and 1997 and

- the extent of the area built up in the last eight years or less.

Table 2: Year data were gathered and the number of years taken into account for each settlement.

\begin{tabular}{|c|c|c|c|c|c|c|c|}
\hline & name of settlement & $\begin{array}{l}\text { aerial photos } \\
\text { for initial } \\
\text { year (GURS) }\end{array}$ & $\begin{array}{l}\text { orthophotos } \\
\text { for the second } \\
\text { period (GURS) }\end{array}$ & $\begin{array}{l}\text { field surveys } \\
\text { (GIAM ZRC } \\
\text { SAZU) }\end{array}$ & $\begin{array}{l}\text { length of first. } \\
\text { interval of } \\
\text { the analysis } \\
\text { in years }\end{array}$ & $\begin{array}{l}\text { length of } \\
\text { second } \\
\text { interval of } \\
\text { the analysis } \\
\text { in years }\end{array}$ & $\begin{array}{l}\text { entire period } \\
\text { (no. of years) }\end{array}$ \\
\hline \multirow[t]{2}{*}{1} & Spodnja Besnica and & & & & & & \\
\hline & Zgornja Besnica & 1992 & 1997 & 2005 & 5 & 8 & 13 \\
\hline 2 & Ihan & 1992 & 1998 in 1999 & 2005 & 6 & 7 & 13 \\
\hline 3 & Brdinje & 1990 & 2000 in 2003 & 2005 & 11.5 & 3.5 & 15 \\
\hline 4 & Lipovci & 1990 & 1999 & 2005 & 9 & 6 & 15 \\
\hline 5 & Krčevina pri Vurbergu & 1992 & 1997 & 2005 & 5 & 8 & 13 \\
\hline 6 & Uršna Sela & 1992 & 2000 & 2005 & 8 & 5 & 13 \\
\hline 7 & Žužemberk & 1992 & 1997 & 2005 & 5 & 8 & 13 \\
\hline 8 & Velike Lašče & 1992 & 1998 & 2005 & 6 & 7 & 13 \\
\hline 9 & Lož and Stari trg pri Ložu & 1992 & 1997 & 2005 & 5 & 8 & 13 \\
\hline 10 & Parecag & 1992 & 1997 & 2005 & 5 & 8 & 13 \\
\hline 11 & Križ and Šepulje & 1991 & 1997 & 2005 & 6 & 8 & 14 \\
\hline
\end{tabular}

The final selection of categories of built-up land from the first level is as follows ( ${ }^{*}$ denotes the most common year; for the precise year for each settlement in question see Table 2):

- residential area - situation in $1992^{*}$

- residential area - situation in $1997^{\star}$ 
- residential area - situation in $2005^{\star}$

- mixed residential and non-residential use - situation in $1992^{\star}$

- mixed residential and non-residential use - situation in 1997*

- mixed residential and non-residential use - situation in $2005^{\star}$

- non-residential use - situation in $1992^{*}$

- non-residential use - situation in $1997^{\star}$

- non-residential use - situation in $2005^{\star}$

- traffic areas (paths, roads, parking lots, railway) 1997

- green space and agricultural land 1997

- water areas 1997

- other unbuilt-up areas (landfills, quarries, and similar) 1997.

At the second level, we determined the activities associated with the building. The source used was the Business Registry of the Agency of the Republic of Slovenia for Public Legal Records and Related Services (Slovene acronym AJPES, data from 31 December 2002). The registry lists centroids of buildings with certain related activities. With its help we also distinguished non-residential and mixed settled areas at the first level described above.

AJPES proved to be problematic in some cases:

- if there was a business activity in the building not recorded by AJPES, since the headquarters of the company were located elsewhere, perhaps even in another settlement,

- if the activity was registered in a building with a purely residential function but took place elsewhere. A good example are independent trucking businesses whose company headquarters are registered at the home address of the owner, but which apart from a truck do not require additional business premises,

- if the activity is recorded at the incorrect location (an error in the RHU or an error in the address - for example Gregorčičeva 1 instead of Stritarjeva 1).

These discrepancies (under 10\%) were in large measure discovered and adjusted for in the field.

Unfortunately our analysis did not include farm households, since we were unable to obtain centroids in the Farm census of European comparable farm households. AJPES keeps records only for agricultural activities as businesses (industrial farms, nurseries, etc.), and farm households do not fall into this classification.

The multitude of activities recorded in the AJPES registry were for the purposes of our analysis grouped into eight categories, the last of which indicated the presence of two or more different activities:

- agricultural activities,

- manufacturing,

- construction,

- trade,

- hotels-restaurants and tourism,

- transport,

- other service activities,

- two or more different activities.

\subsection{Terminology}

\section{Settlement area}

The area of the settlement taken into account was that within the boundaries valid in 2002 (source: Surveying and Mapping Authority of the Republic of Slovenia).

The total area of all of the settlements studied, i. e. 8 independent settlements and 3 pairs of settlements, was 9664.57 ha.

\section{Settled area}

The settled areas were defined based on $\operatorname{Krevs}(2004,79)$. These are densely settled areas and dispersedly settled areas taken together, or in other words: the area of buildings plus a 100-meter radius or green belt around them. Settled areas consist of: built-up areas, traffic areas, sports grounds, and scattered patches of greenery, farm land, forest, and water. All of the unsettled areas of the settlement, i. e. large tracts of forest, agricultural land, and water, were excluded from the analysis. 


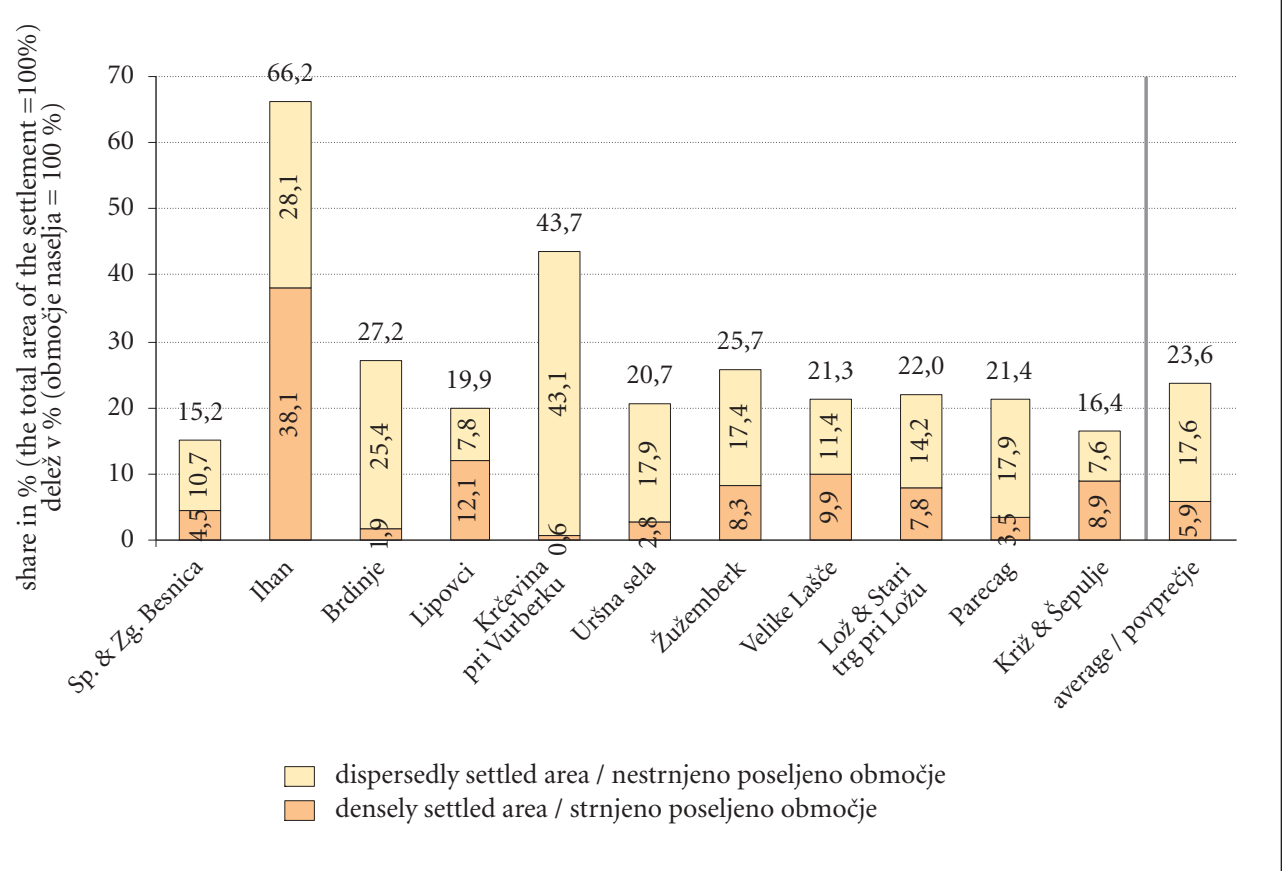

Figure 3: The share of settled areas within the total area of the settlement (data from 2004)

There was a total of 2277.32 ha of settled areas in all of the settlements studied, or $23.5 \%$ of the total area of the settlements. Settled areas were further divided into:

- densely settled areas, which according to Krevs $(2004,79)$, consist of areas of buildings together with a 100-meter radius of greenery around them, in which the share of built-up areas is greater than $5 \%$. Densely settled areas took up 573.26 ha, or $25.2 \%$ of the settled areas of the settlements in our sample.

- dispersedly settled areas are areas of buildings together with a 100-meter radius of greenery around them in which the share of built-up areas is $5 \%$ or less. Dispersedly settled areas took up 1704.07 ha or $74.8 \%$ of the settled areas of the settlements in our sample.

Settlements were classified in three groups with respect to settlement type: the most clustered were nucleated settlements (Lipovci, Ihan, Križ and Šepulje and Lož and Stari trg pri Ložu). The densely settled portion of these settlements took up 46 to $61 \%$ of the settled area. Settlements with a nucleated center but an otherwise dispersed settlement pattern (Spodnja Besnica and Zgornja Besnica, Žužemberk and Velike Lašče) had 30 to $36 \%$ densely settled areas. In dispersed settlements (Krčevina pri Vurbergu, Brdinje, Uršna sela and Parecag), the dispersedly settled parts of the settlement took up only 1 to $17 \%$ of the settled areas.

\section{Built-up areas}

Buildings having different functions were taken into account in the framework of built-up areas:

- residential buildings, which can be:

- individual residential buildings, to which belong: buildings which are:

- single-family houses and multi-generational family houses,

- duplexes,

- row houses and

- farms (farm house along with outbuildings) and

- apartment buildings which house a number of families and are multi-storey, with four or more apartments, 


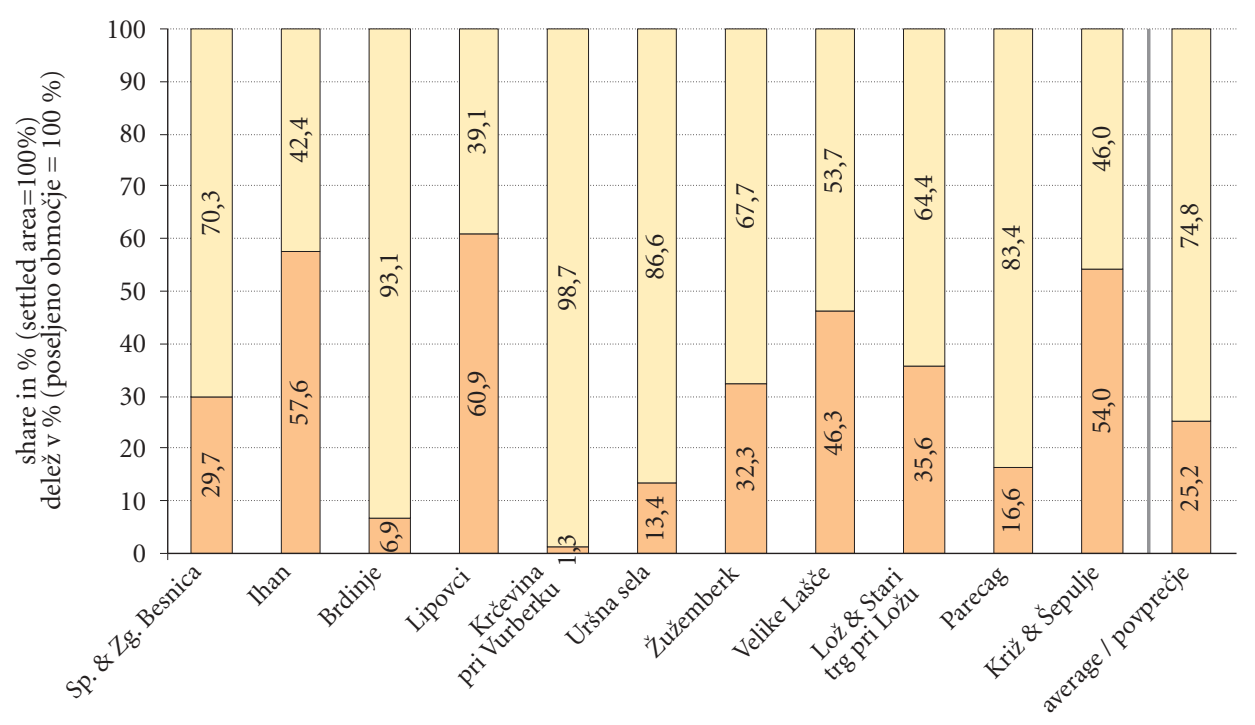

dispersedly settled area / nestrnjeno poseljeno območje

densely settled area / strnjeno poseljeno območje

Figure 4: The share of densely and dispersedly settled areas in the total settled areas of the settlement (2004).

- buildings with a mixture of functions, which are intended for both residence and other activities (exceptionally only the company headquarters are located there). A non-residential function may be economic or not (for example, the company headquarters).

- non-residential buildings (intended only for activities; also included are internal traffic areas which support these activities). Non-residential buildings may be buildings with economic activities (and jobs) or have some other function, for example a firehouse, a village hall, etc., and

- buildings without a function (this includes all buildings no longer in use, regardless of original function). Most commonly these are abandoned houses and farm buildings.

In addition to the buildings themselves, accompanying gardens, courtyards, driveways or other so-called functional areas, whose width and length do not exceed $17 \mathrm{~m}$, are included in the area considered to be built-up. The size of these unbuilt-up areas does not allow for the construction of new, free-standing buildings, but only additions to existing buildings.

In all the settlements studied there is a total of 290.73 ha of built-up areas, which is $12.8 \%$ of the total settled areas (203.49 ha or 35.5\% in densely settled areas and 87.2 ha or $5.1 \%$ in dispersedly settled areas). $70 \%$ of the total built-up area for all the settlements lies in densely settled areas and $30 \%$ in dispersedly settled areas. It should be noted that the built-up areas and their relative proportions would be higher if the data were presented as parceled lots. The share of built-up areas in individual settlements is related to the type of settlement pattern, i. e. the morphology of the settlement. The basic characteristics of building are as follows.

In dispersed settlements, composed of hamlets and free-standing buildings, the share of built-up areas is less than 10\% (5.8-8.1\%) - these are settlements such as Brdinje, Krčevina pri Vurbergu, Uršna sela and Parecag.

In villages with more concentrated settlement patterns, i. e. a nucleated or roadside linear pattern, the share of built-up areas exceeds 20\% (21.7-43.4\%) - these are settlements such as Ihan, Lipovci, Lož-Stari trg and Križ-Šepulje.

In Velike Lašče, Žužemberk and Spodnja Besnica and Zgornja Besnica the two types are intermixed the share of built-up areas in the settled area amounts to 10 to $20 \%$. These settlements are characterized by a large difference in the density of settlement and building between the densely settled and dispersedly settled parts of the settlement. 


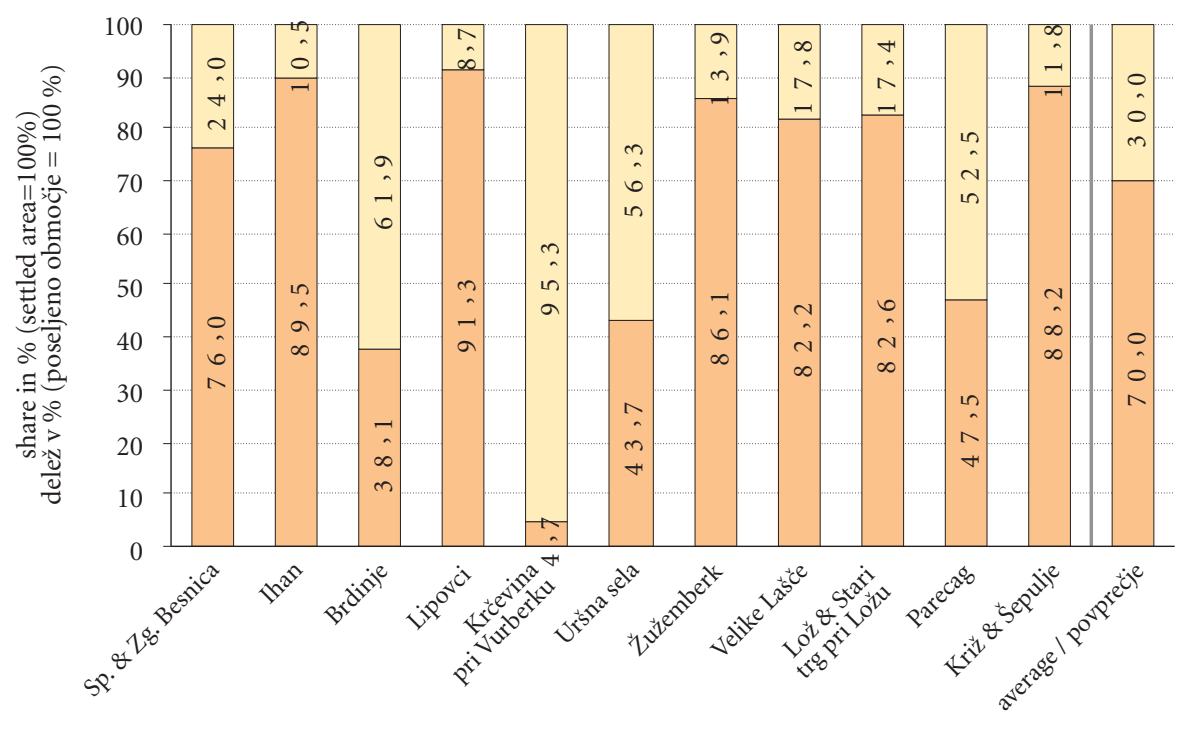

dispersedly settled area / nestrnjeno poseljeno območje

densely settled area / strnjeno poseljeno območje

Figure 5: The share of built-up areas in densely settled and dispersedly settled parts of the settled area of the village (data from 2004).

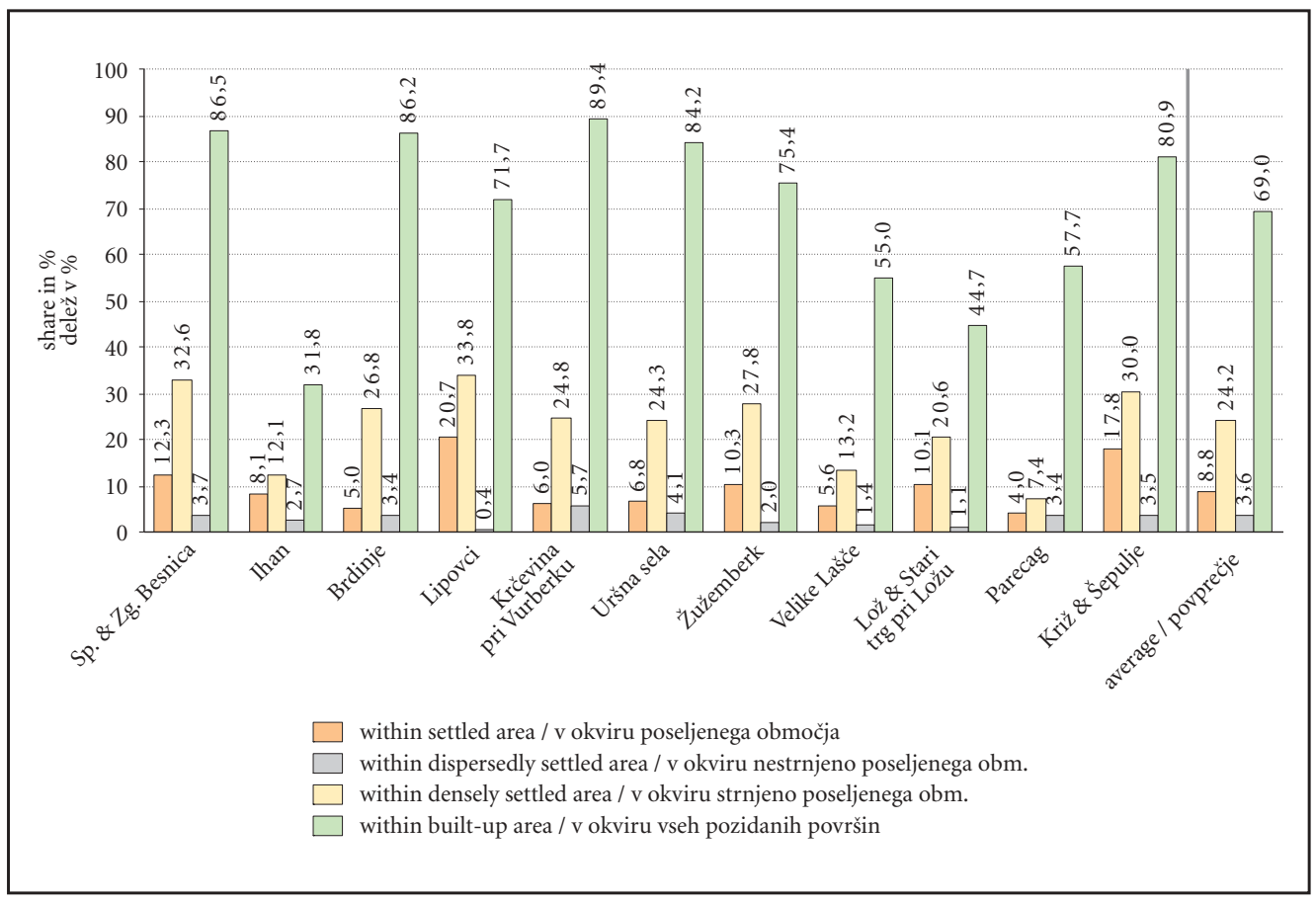

Figure 6: Residential areas in settlements in 2005. 


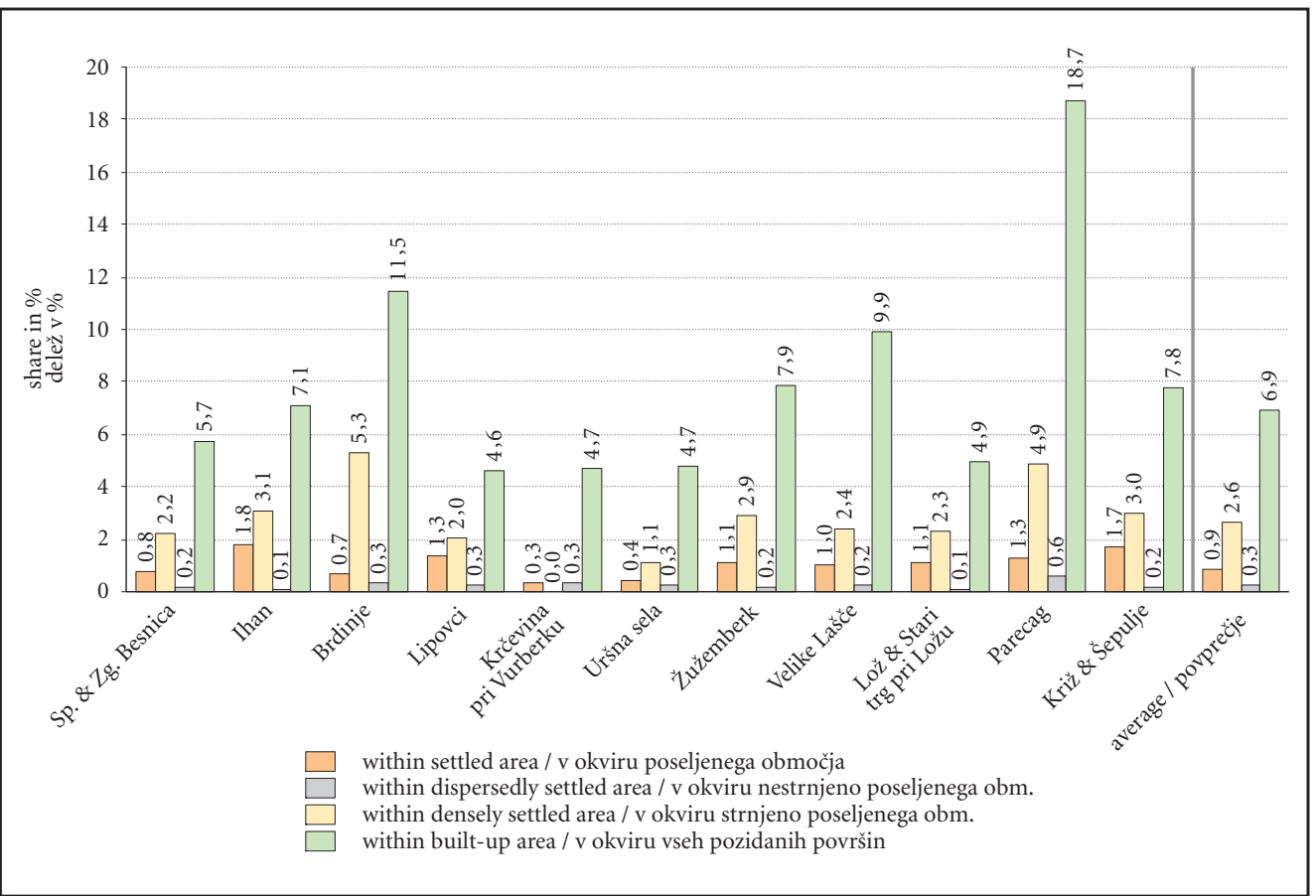

Figure 7: Areas with a mixture of functions (residential and activities) in settlements in 2005.

\section{Residential areas}

Residential areas covered a total of 202.94 ha or $8.8 \%$ of all settled areas (range: $4.0 \%-20.7 \%$ ). Of these, 140.9 ha $(24.6 \%$ of the total settled area, range: $8.5 \%-33.8 \%)$, were in densely settled areas, and 64.55 ha or $3.6 \%$ in dispersedly settled areas (range: $0.4 \%-5.7 \%$ ).

$69.4 \%$ of residential areas thus belong to densely settled areas and $30.6 \%$ to dispersedly settled areas in the settlements.

The residential areas took up $69.0 \%$ on average (range: $31.8 \%-89.4 \%$ ) of the built-up areas in the settlements. This share was lower in the settlements of Ihan, Lož and Stari trg pri Ložu and Velike Lašče, which have large areas for non-residential purposes and activities; in the absence of these, the share would be $81.3 \%$.

Detached residential houses strongly predominated among the residential buildings, accounting for $98.8 \%$.

Multi-unit apartment buildings in the settlements studied covered only an area of 2.37 ha, or $1.2 \%$ of the total residential area in settled areas (1.6\% in densely settled areas and an almost negligible $0.2 \%$ in dispersedly settled areas) and $0.8 \%$ in built-up areas. Multi-unit apartment buildings were present only in the settlements of Parecag, Lož and Stari trg pri Ložu, Ihan, Žužemberk and Velike Lašče. The number of such buildings was less than 10 in each case, and they were usually quite small. During the period studied only two new multi-unit apartment buildings were built, in the centers of Ihan and Stari trg pri Ložu. In most other cases the buildings date from the 1960s and 1970s.

\section{Areas with a mixed residential/non-residential function}

Buildings with a mixed function, serving both residential and non-residential purposes, cover a total of 20.03 ha or $0.9 \%$ of the settled areas (range: $0.3 \%-1.7 \%$ ), or $6.9 \%$ of the built-up areas. 15.0 ha of the mixed areas are in densely settled areas (3.5\%) while 5 ha or $1.2 \%$ lie in dispersedly settled areas. Thus three-fourths of areas with a mixed function lie in densely settled parts of settlements and one-fourth in dispersedly settled parts. 


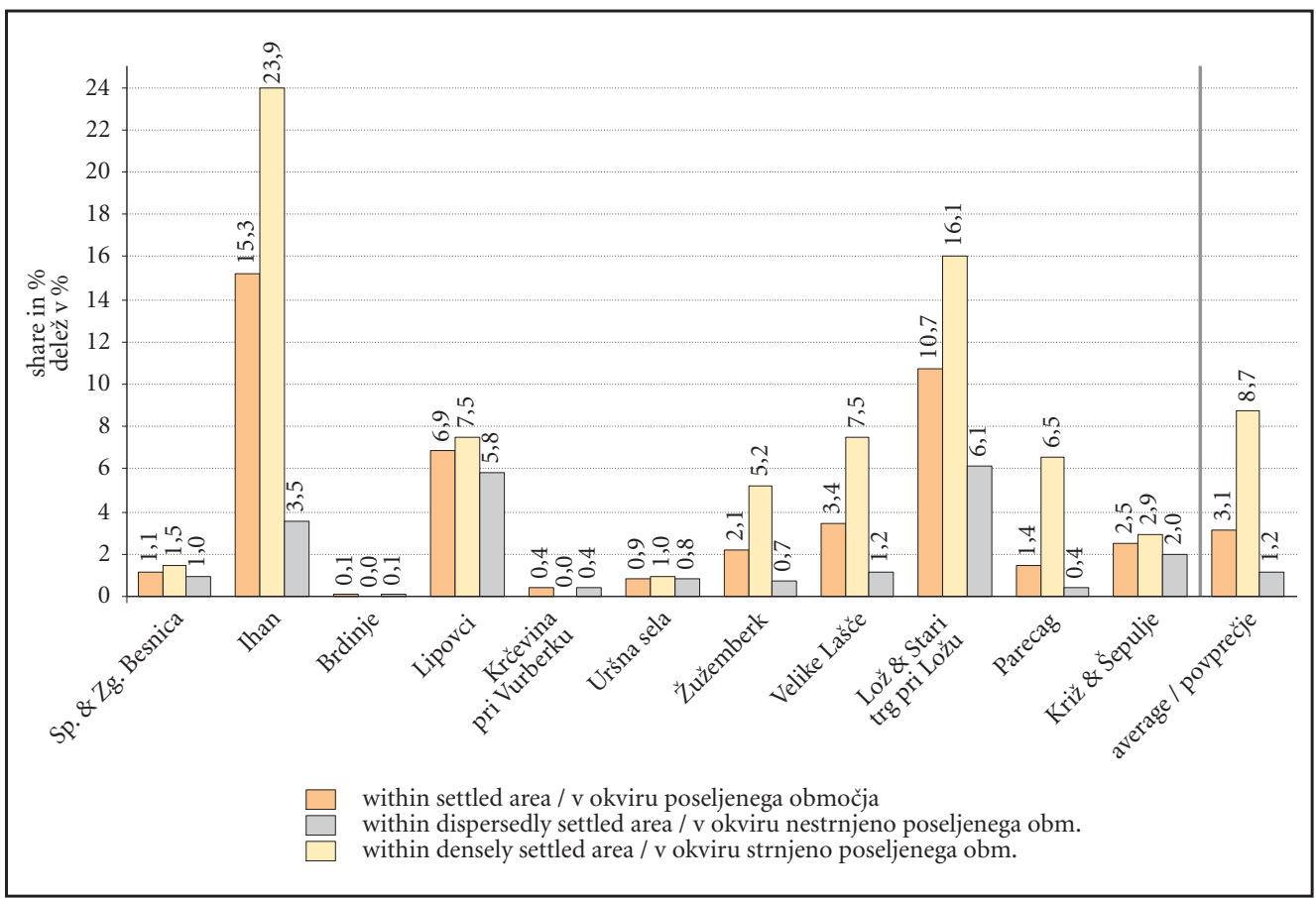

Figure 8: Areas devoted to activities in settlements in 2005.

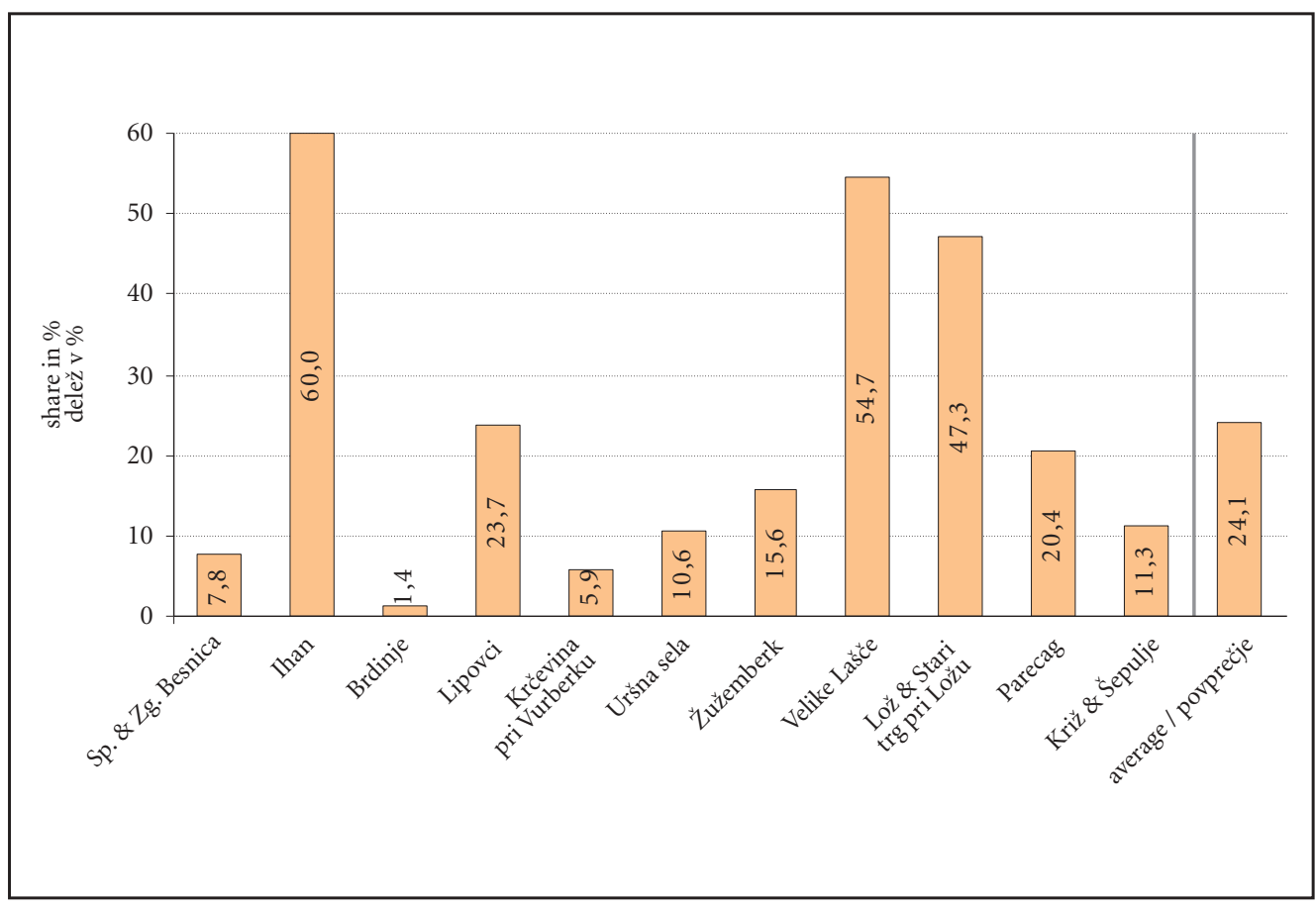

Figure 9: Share of areas devoted to activities within all built-up areas of settlements in 2005. 


\section{Areas with non-residential buildings}

Areas with buildings which serve non-residential activities took up 70.13 ha in area, or $3.1 \%$ of the settled parts of settlements (range: $0.1 \%-15.7 \%$ ) and $24.2 \%$ of built-up areas (range: $1.4 \%-60.0 \%$ ). 50 ha of this area lie in densely settled areas, where they take up $8.7 \%$ of the total (range: $0 \%-23.9 \%$ ), 20.14 ha lie in dispersedly settled areas, where they occupy $1.2 \%$ of the area (range: $0.1 \%-6.2 \%$ ). $71.3 \%$ of the areas intended for such activities are located in densely settled areas and $28.7 \%$ in dispersedly settled areas. Settlements which have the highest shares of areas devoted to activities in built-up parts are: Ihan (60\%), Lož and Stari trg pri Ložu (47.3\%) and Velike Lašče (33.3\%).

\section{Buildings without a function}

Buildings without a function take up small areas in Brdinje, Uršna sela and Žužemberk; Lož and Stari trg stand out most in this respect ( $0.9 \%$ of built-up areas). In total they take up a little more than half a hectare $(0.1 \%$ of settled areas). They are relatively more frequent in densely settled parts $(0.2 \%)$.

\section{Traffic areas}

Traffic areas include transportation routes (roads, paths, railways) and parking areas. Traffic areas within fenced industrial and other areas which serve the internal needs of the businesses there were excluded. These traffic areas were taken into account in the framework of those activities.

According to the classification of the Directorate of the Republic of Slovenia for Roads, the following types of traffic areas are distinguished:

- national traffic areas, which includes motorways, major highways, category I and II main roads, and category I, II, and III regional roads.

- other traffic areas, which include the remaining public roads - municipal roads (local roads and public paths) and private roads and paths (driveways and roads, farm lanes, and paths within agricultural and green areas in the settled parts of settlements).

In the settlements studied, 114.91 ha belonged to traffic areas, which is a share of $5.1 \%$ of the settled areas (range: $3.6 \%-11.8 \%$ ). Of these areas, only 14.4 ha, or $12.5 \%$, were national roads.

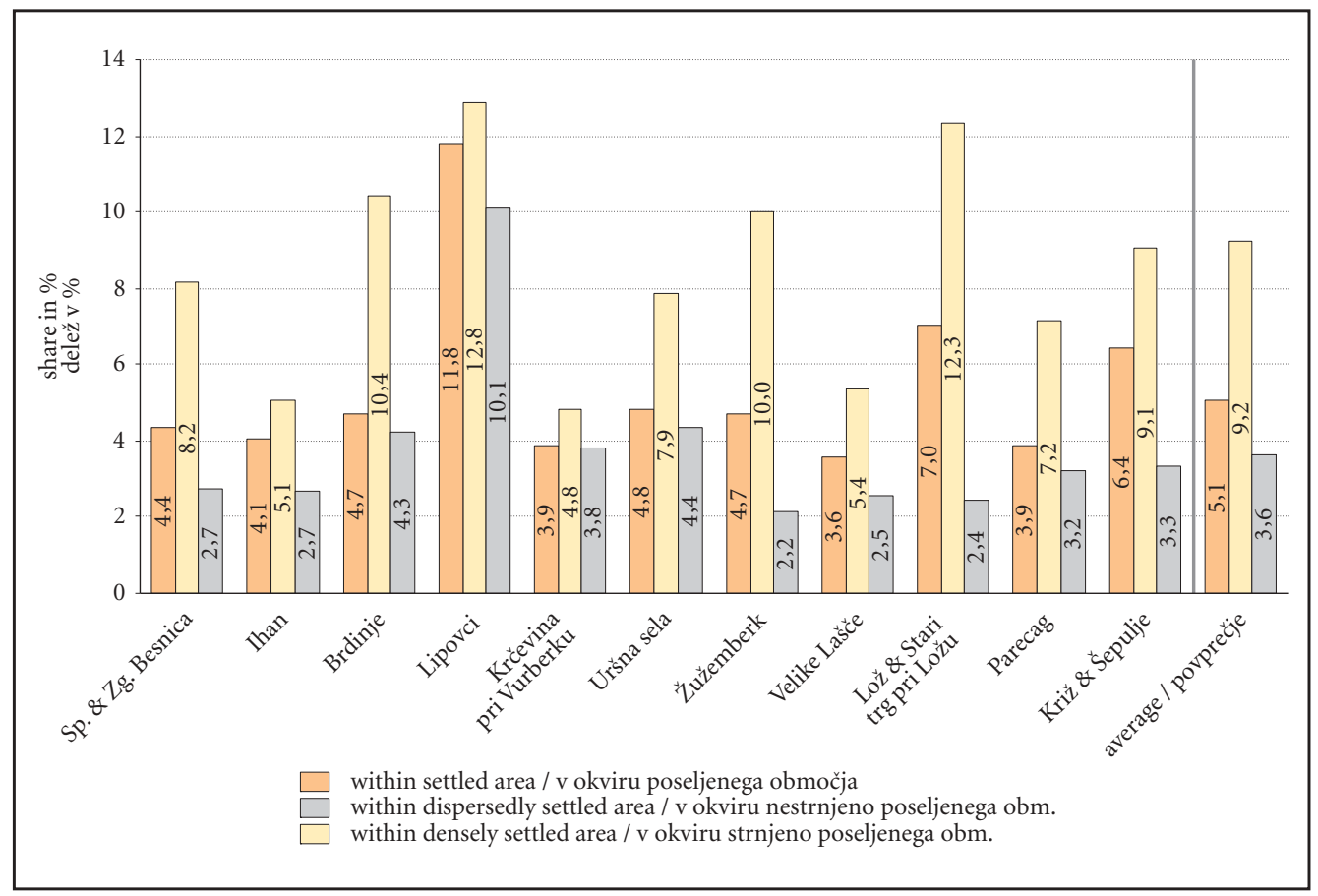

Figure 10: Traffic areas in the settled parts of the villages in 2005. 


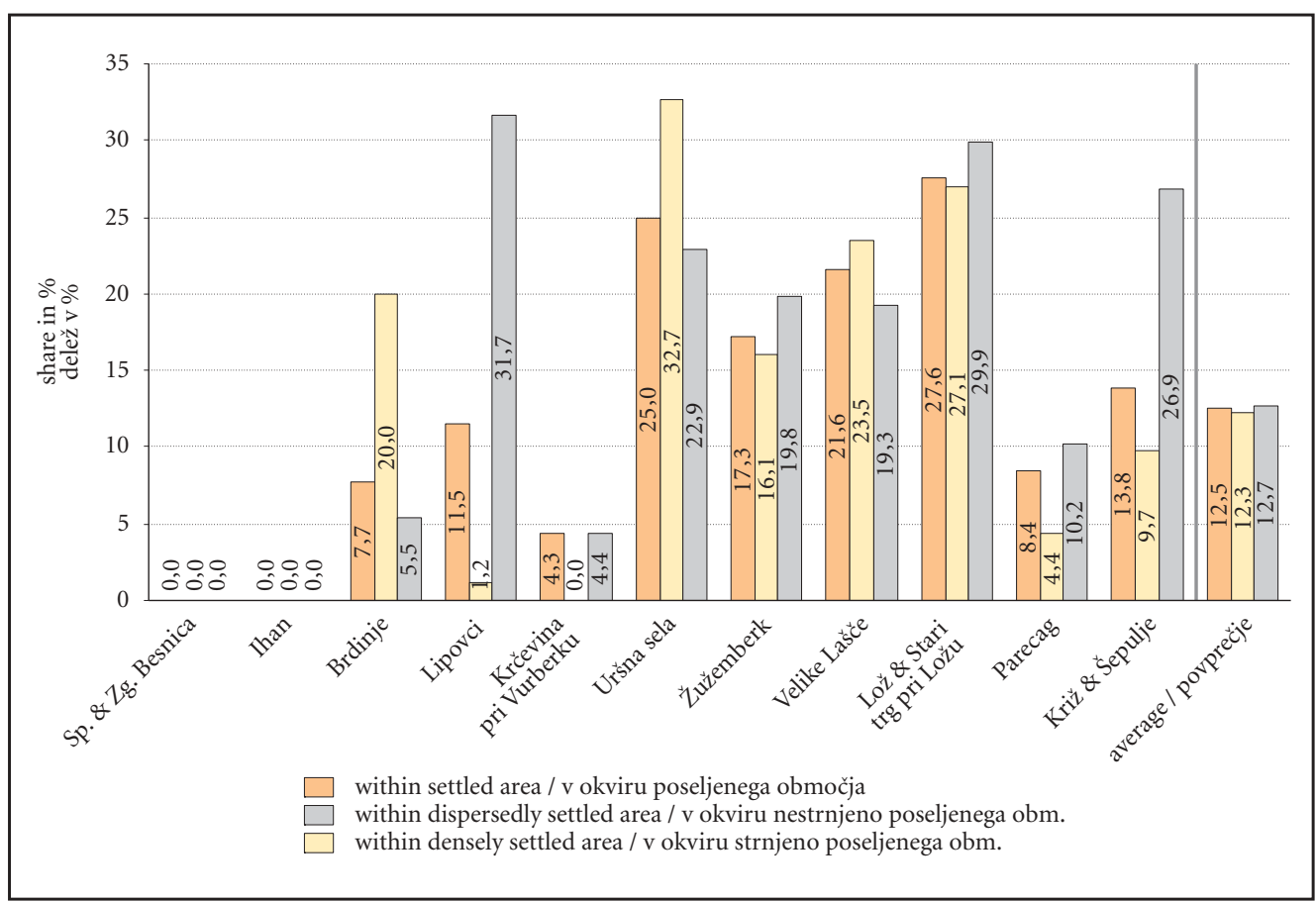

Figure 11: The share of national roads in the framework of all traffic areas in densely settled areas of settlements in 2005.

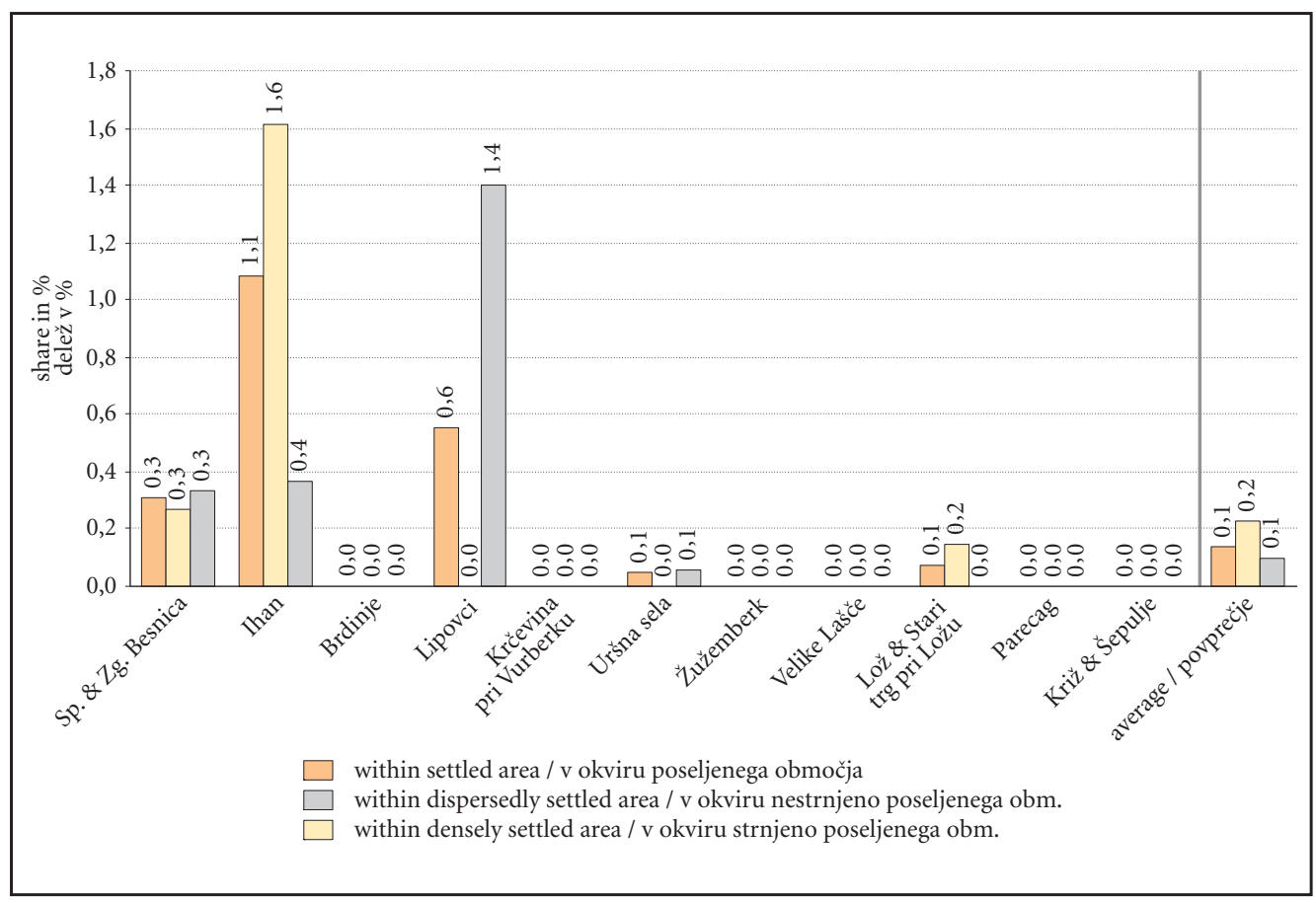

Figure 12: Sports grounds and parks in the settled parts of the settlements in 2005. 


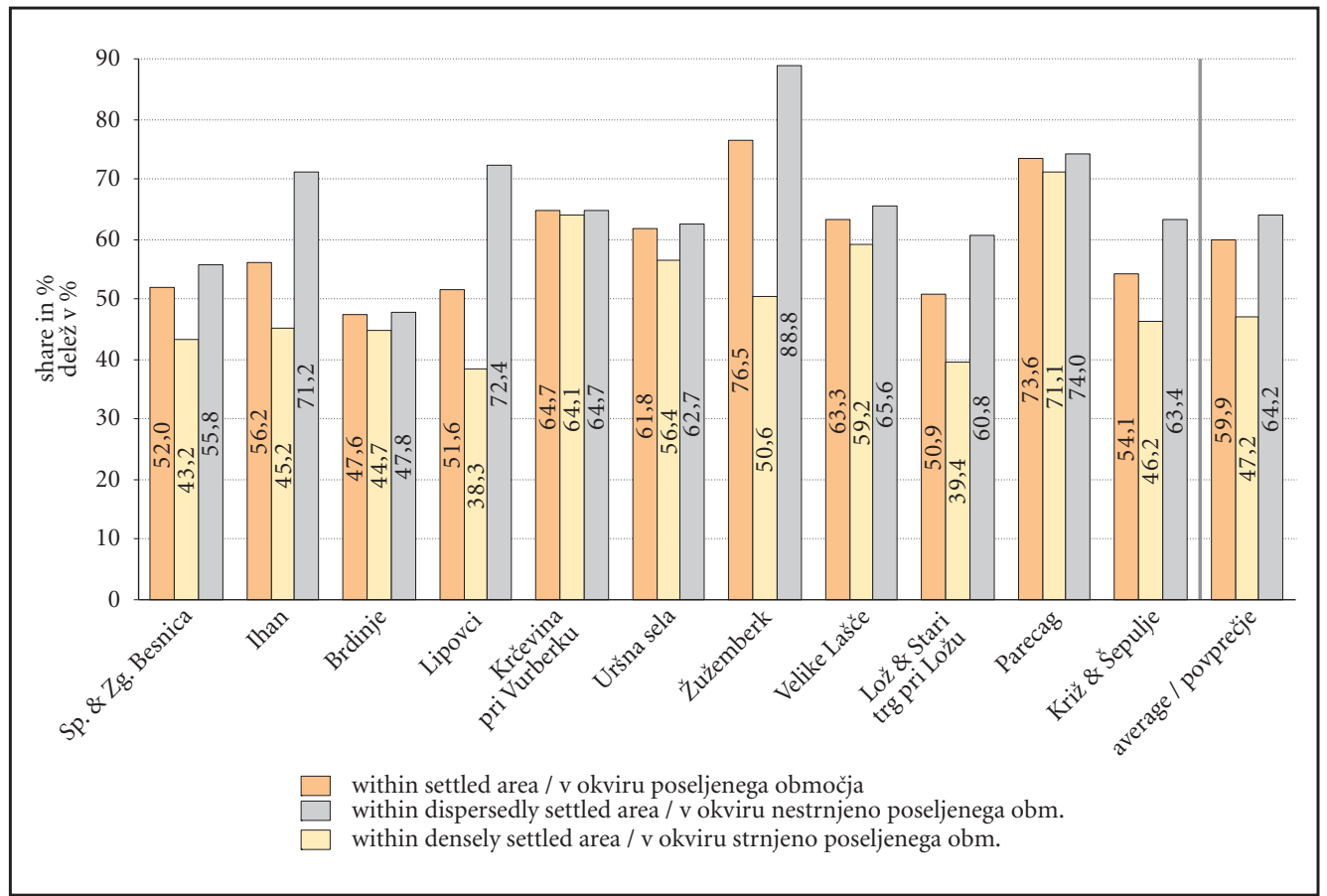

Figure 13: Green and agricultural areas in the settled parts of the settlements in 2005.

We were especially interested in the difference between densely settled areas and dispersedly settled areas. We looked closely at the nucleated settlement of Spodnja Besnica, which is comparable in the layout of its buildings to an urban area. The built-up areas here occupied more than two-thirds of the area, with larger islands of green accounting for $14.7 \%$, and traffic areas for as much as $15.2 \%$.

There are 52.85 ha of traffic areas in the densely settled areas ( $9.2 \%$ of the total area - range: $4.8 \%-12.9 \%)$, and 62.06 ha $(3.6 \%$ of the total area - range: $2.2 \%-10.2 \%)$ in dispersedly settled areas. The Pannonian settlement of Lipovci stands out among dispersedly settled areas with an exceptionally high share of traffic areas $(10.2 \%)$, since a corridor of national importance runs through it. Otherwise, shares of traffic areas are between 2 and 3\% in nucleated settlements. Only the settlements of Brdinje and Uršna sela have shares over $4 \%$ in dispersedly settled areas due to their dispersed layout; Krčevina pri Vurbergu also comes close to this figure.

$46 \%$ of traffic areas are found in densely settled areas and 54\% in dispersedly settled areas. The share of national roads in the total traffic areas is similar for both types of areas (12.3 and 12.7\%).

\section{Sports grounds and parks}

Sports grounds cover only 3 ha $(0.1 \%)$ of all the settled areas. They were found in only 6 of the 11 units. They are more frequent where there is an above average share of jobs (Ihan, Lipovci, Lož and Stari trg), if there is a large share of second homes in the settlement (Uršna sela), or if there is a major urban center nearby (Besnica).

\section{Green and agricultural areas}

Green and agricultural areas include relatively large gardens (wider and longer than $17 \mathrm{~m}$ ), lawns, parks, and agricultural areas (crop-fields, meadows and pastures) - all within the confines of the settled part of the settlement. Stands of forest and consolidated agricultural areas are excluded from the analysis.

A total of 1364.90 ha or $59.9 \%$ of the total area of settled areas is green space or agricultural land (range: $47.6 \%-73.6 \%$ ). 19.8\% (270.59 ha) of this is in densely settled areas; within these areas such land takes 


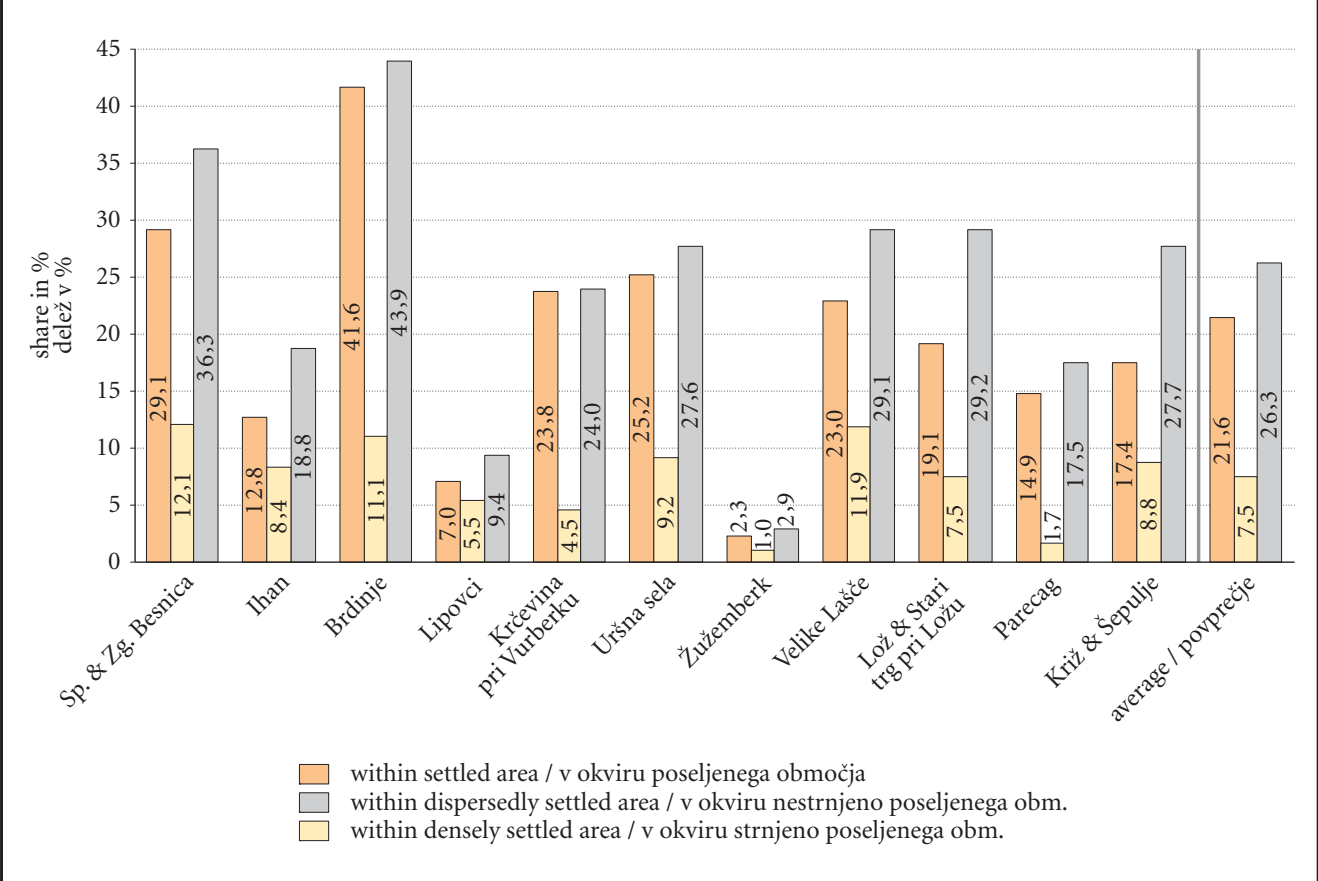

Figure 14: Forest areas found in the settled parts of the settlements in 2005.

up $47.2 \%$ of the area (range: $38.3 \%-71.1 \%$ ). $80.2 \%$ of all green space and agricultural land (1093.88 ha) is found in areas with dispersed settlement; within such areas this land takes up $64.2 \%$ of the total area (range: $47.8 \%-74.0 \%$ ). Settlements which have the lowest share of green space and agricultural land are: Brdinje, both villages of Besnica, and Lož and Stari trg. In the first two instances the reason for this is their dispersed layout, such that the intervening green and agricultural areas are categorized occur in large unbroken tracts and are thus excluded, while in the case of Lož the low share is due to the density of building.

\section{Forest areas}

Forest areas found within the settled part of the settlement are taken into consideration. Their area amounts to 491.10 ha, or $21.6 \%$ of the settled area. In densely settled areas, this share is only $7.5 \%$ (range: $1.0 \%-12.1 \%$ ), in areas with dispersed settlement the figure exceeds one fourth (26.3\%, range: $2.9 \%-43.9 \%)$. Two settlements in upland areas - both villages of Besnica and Brdinje in Koroška, a village consisting mainly of isolated farms - are heavily forested.

\section{Water areas}

Only water areas found within the settled part of the settlement are included. Their area amounted to only 11.68 ha or $0.5 \%$ of the settled area. Some regions, especially in the Karst, have no water areas at all. Žužemberk has an exceptionally high proportion, since the Krka River flows through the densely settled area, taking up $2.8 \%$ of the total area.

\section{Socioeconomic characteristics of the settlements in the sample}

The most common method for identifying the socioeconomic characteristics of a settlement is through an analysis of the economically active population in the settlement and an analysis of the functions which the settlement has. Based on the 2002 Census, we determined the commuting patterns of the population, 


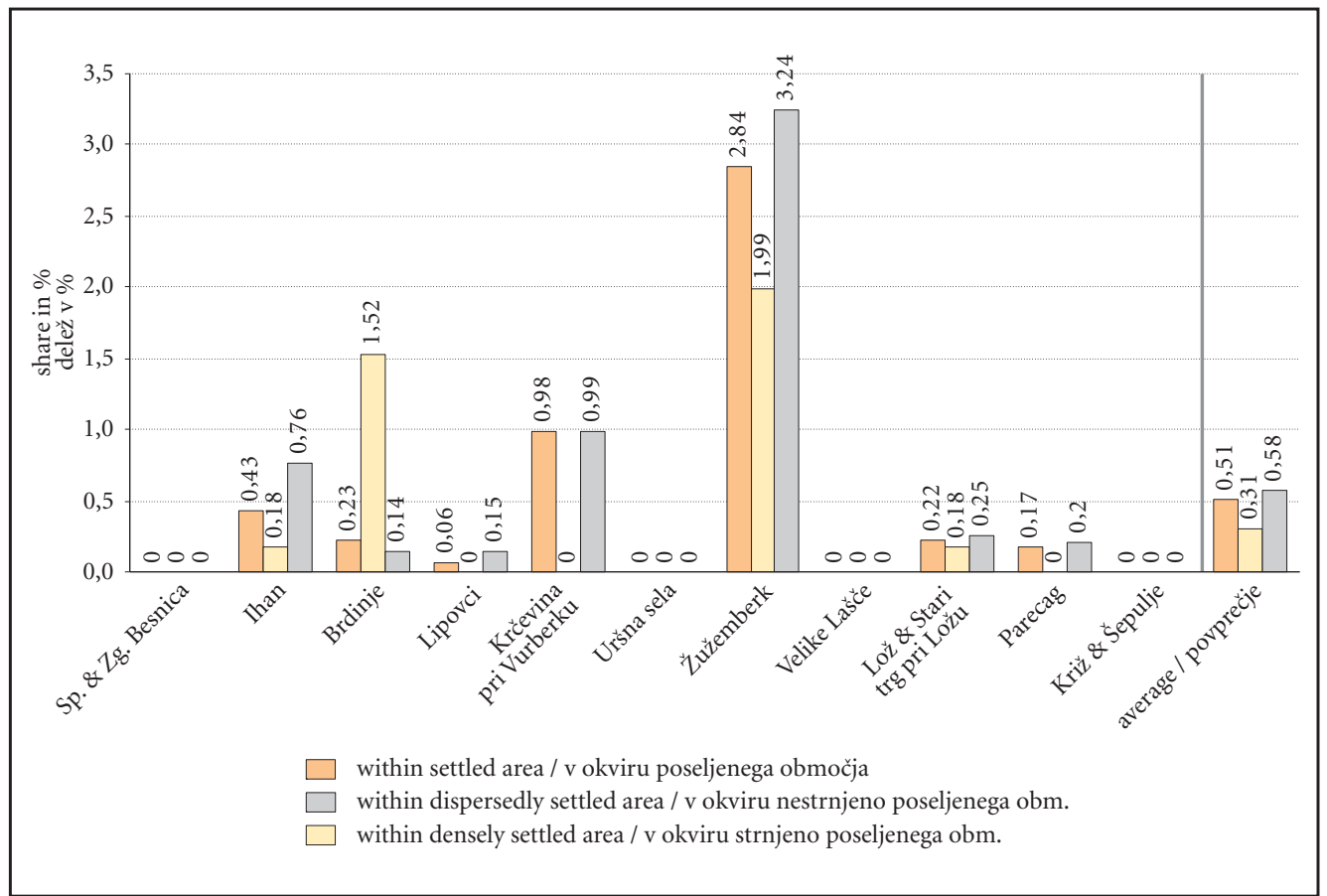

Figure 15: Water areas in the settled parts of settlements in 2005.

the ratio between the number of employed and the number of jobs in the settlement, and the role in the hierarchical network of settlements. For a more detailed determination of the types of activities of companies, we used the Business Register of Slovenia (Slovene acronym PRS - AJPES) for 2002.

The daily commuting patterns of the economically active population is a basic indicator of the social characteristics of individual settlements. They can be shown by means of the share of daily commuters within the total number of economically active inhabitants residing in a given settlement. A commuter is any employee who travels to work in a settlement outside the settlement of his or her residence. Figure 16 shows the value of this indicator for the sample of rural settlements selected. There is a large difference evident between the settlements of Lož and Stari trg pri Ložu, where the share of commuters is much lower than in the other settlements. The settlements Uršna sela, Zgornja Besnica and Spodnja Besnica and Brdinje have extremely high values. In the majority of settlements in our sample the number of jobs and their structure is not in equilibrium with the economically active population. This leads to increased levels of commuting by residents. These data are not surprising, since agriculture, which was at one time the economic mainstay of rural areas, no longer plays a very visible role. The economically active population thus seeks employment in urban settlements where most jobs are concentrated.

In our sample of settlements the majority of the economically active population commute to jobs in larger urban settlements: from Brdinje to Ravne (more than 50\%), from Križ and Šepulje to Sežana (51\%), from Lipovci to Murska Sobota (52\%), from Uršna sela to Novo mesto (75\%), and so on. From Velike Lašče the majority (58\%) of the economically active population commute to the relatively distant city of Ljubljana. On average, $74 \%$ of the economically active population of the settlements in our sample commute elsewhere to jobs; the average for Slovenia as a whole is $54.6 \%$.

Also important are data on the economically active population according to place of residence and place of employment. Only Lož-Stari trg and Žužemberk show a surplus of jobs over the number of the economically active population (Figure 17). Lož-Stari trg pri Ložu has an especially high number of jobs in the manufacturing plant of Kovinoplastika Lož, and represents an important center of employment for nearby settlements. Žužemberk is also a large center of employment, with more jobs than the num- 


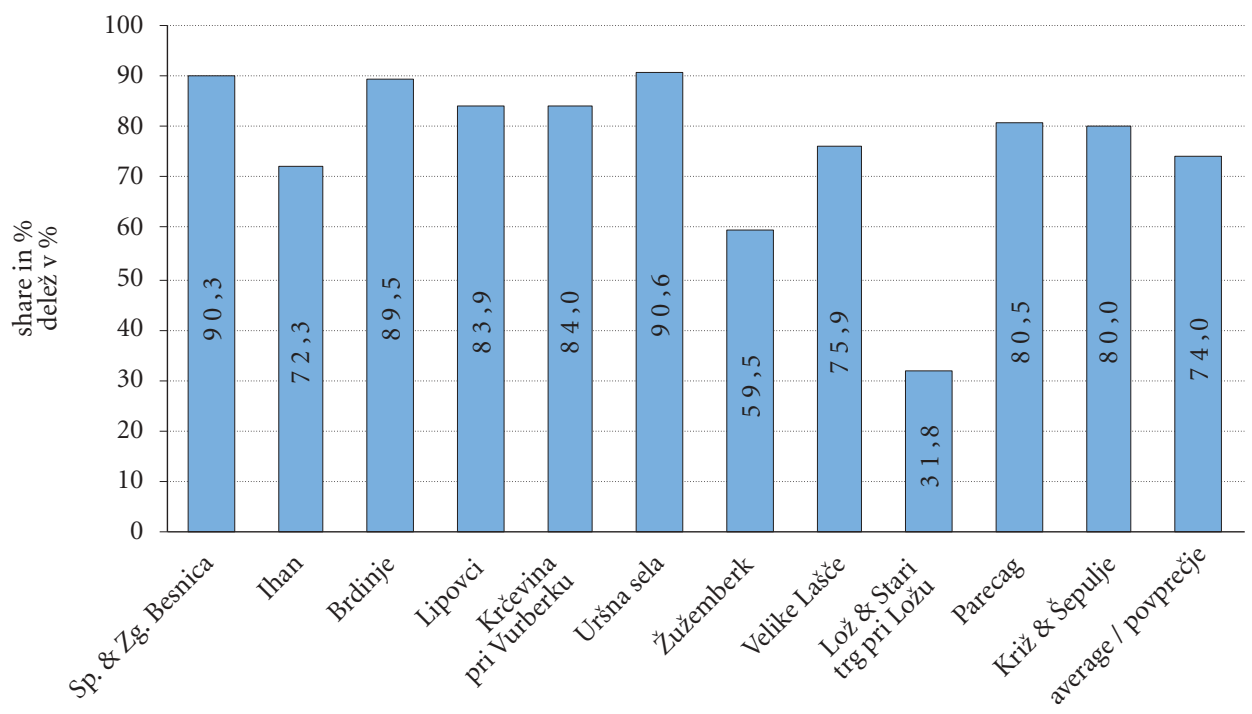

Figure 16: Share of commuters (daily migrants) in the economically active population.

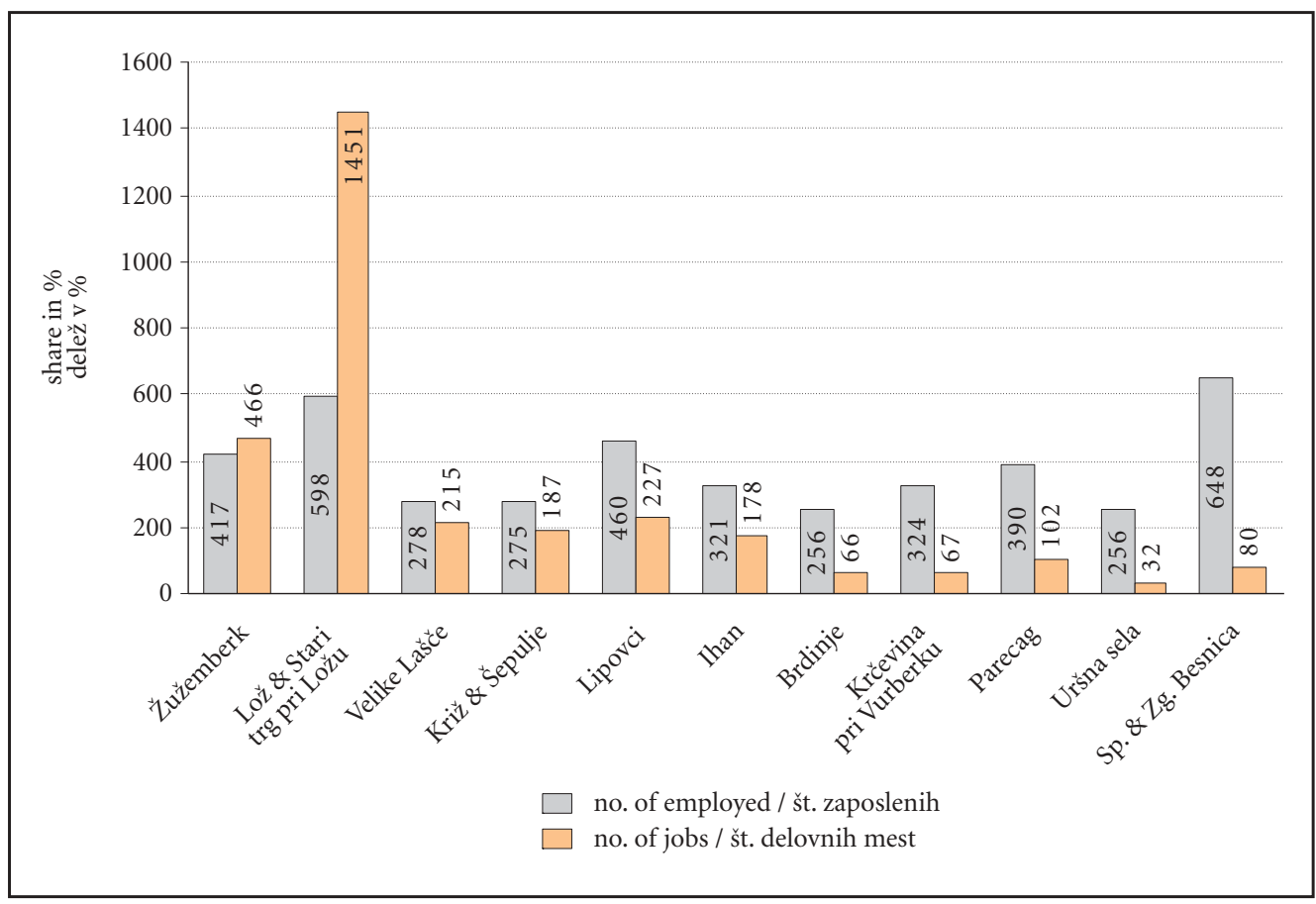

Figure 17: The ratio between the number of employed and the number of jobs. 
ber of economically active people living in the settlement. The remaining settlements have fewer jobs and are source areas of the labor force. Zgornja Besnica and Spodnja Besnica, Uršna sela, Krčevina pri Vurbergu, Parecag and Brdinje have a low number of jobs and there are large flows of commuters to nearby centers of employment.

A similar indicator is locational divergence, the coefficient of the economically active population according to place of residence and place of employment. Locational divergence $=\mathrm{Z} / \mathrm{DM}$, where $\mathrm{Z}$ is the economically active population according to place of residence and DM is the economically active population according to place of work (number of jobs). Conditions are optimal when the number of workers in a given region is in equilibrium with the number of jobs within a settlement, i. e. the value of locational divergence is 1 (Ravbar 2002,18). A value lower than 1 indicates a greater number of jobs over employed, and a value higher than 1 indicates a greater number of employed than there are jobs in a given settlement (see Table 3). The range in the settlements studied extends from 0.41 (Lož/Stari trg pri Ložu) to 8.1 (Zgornja Besnica and Spodnja Besnica). The settlements of Lipovci, Ihan and Križ/Šepulje have a more balanced locational divergence due to the presence of some industrial plants: an industrial livestock farm in Ihan, a meat-processing plant in Šepulje, and a pharmaceutical plant in Lipovci.

Table 3: Typing of the expert sample of rural settlements

\begin{tabular}{|c|c|c|c|c|c|c|c|}
\hline $\begin{array}{l}\text { name of } \\
\text { settlement }\end{array}$ & $\begin{array}{l}\text { no. of } \\
\text { employed }\end{array}$ & $\begin{array}{l}\text { no. of } \\
\text { jobs }\end{array}$ & $\begin{array}{l}\text { locational } \\
\text { divergence }\end{array}$ & $\begin{array}{l}\text { proportion of } \\
\text { jobs taken by } \\
\text { workers who } \\
\text { live in the same } \\
\text { settlement }\end{array}$ & $\begin{array}{l}\text { proportion of } \\
\text { commuters in } \\
\text { the total working } \\
\text { population of } \\
\text { the settlement }\end{array}$ & $\begin{array}{l}\text { degree of centrality } \\
\text { of the settlement } \\
\text { (Vrišer 1998). }\end{array}$ & $\begin{array}{l}\text { type of } \\
\text { settlement }\end{array}$ \\
\hline Žužemberk & 417 & 466 & 0.89 & 36.27 & 59.47 & 2 & I \\
\hline Lož and Stari trg pri Ložu & 598 & 1451 & 0.41 & 28.12 & 31.78 & 2 & I \\
\hline Velike Lašče & 278 & 215 & 1.29 & 31.16 & 75.9 & 2 & I \\
\hline Križ and Šepulje & 275 & 187 & 1.47 & $\begin{array}{l}\text { data not } \\
\text { available }\end{array}$ & 80 & - & $\|$ \\
\hline Lipovci & 460 & 227 & 2.03 & 32.60 & 83.91 & - & ॥ \\
\hline Ihan & 321 & 178 & 1.80 & 43.26 & 72.31 & 1 & $\|$ \\
\hline Brdinje & 256 & 66 & 3.87 & 40.91 & 89.45 & - & III \\
\hline Krčevina pri Vurbergu & 324 & 67 & 4.83 & 77.61 & 83.96 & 1 & III \\
\hline Parecag & 390 & 102 & 3.82 & 74.51 & 80.51 & - & |ll \\
\hline $\begin{array}{l}\text { Uršna sela } \\
\text { Spodnja Besnica and }\end{array}$ & 256 & 32 & 8.00 & 75.00 & 90.62 & 1 & III \\
\hline Zgornja Besnica & 648 & 80 & 8.10 & 77.50 & 90.28 & 1 & III \\
\hline
\end{tabular}

The socioeconomic characteristics of the sample of settlements can also be determined by the degree of centrality, which represents the basic characteristics of the spatial organization of society in Slovenia. According to Vrišer (1998), there are 612 central settlements with various functions in Slovenia, which meet the needs not only of the residents of those settlements but also of other users in their hinterland. In our sample, Žužemberk, Stari trg pri Ložu and Velike Lašče, which are level 2 central settlements or vicinal centers, have the highest position in the hierarchical network of settlements. They have some relatively specialized services such as a medical center, bank branch, pharmacy, police station and specialized shops. Four settlements are classified as level 1 centers (the lowest level): they have a primary school for either all nine grades or the first five, a grocery store, and they are seats of their local communities. The other settlements do not fulfill these conditions and are not central settlements. Other authors (Ravbar et al. 2001, Cigale 2002) have made similar classifications, in which the settlements of Žužemberk, Velike Lašče and Stari trg pri Ložu are usually ranked in a higher category with respect to centrality than the other rural settlements.

On the basis of these data selected, we can classify the settlements in our sample of rural settlements into three basic types (Table 3):

I. Settlements which are local centers and have an important employment function. They represent centers of employment for the smaller settlements in their environs, and are at the same time administrative centers (seats of municipalities). In our case these are the settlements of Žužemberk, Lož/Stari trg pri Ložu and, partially, Velike Lašče. These settlements have some developed administrative functions and 
represent a destination for commuters to jobs from their immediate environs, and Lož and Žužemberk in particular also have a strong production function (industry). Suburbanization is less pronounced, due to geographical remoteness and other functions (primarily due to the development of other functions). For these settlements, from the standpoint of future land use, we predict primarily a strengthening of the role of supply and other services (tertiary activities) and other public infrastructure. The expansion of residential areas is less intensive.

II. The next group consists of settlements which have a limited employment function and where the number of commuters (daily migrants) from the settlement traveling to jobs elsewhere is larger than the number of commuters from outside traveling to jobs in the settlement. These are settlements which have, in addition to jobs in agriculture, a small number of jobs in individual manufacturing plants thanks to the policy of polycentric development in the past. Nevertheless the majority of inhabitants seek work outside the settlement, in nearby urban centers. The settlements of Križ, Šepulje, Ihan and Lipovci fall into this group. In the case of all the aforementioned settlements, there are larger urban centers in the immediate vicinity, which these settlements are completely dependent on administratively and to a large extent also for supply. The reason for changes in land use is suburbanization, which leads to a greater demand for housing and accompanying municipal and road infrastructure, and to a smaller degree also functions relating to supply and services.

III. The third group are settlements which have virtually no employment function and are functionally fairly homogeneous. These are Zgornja Besnica and Spodnja Besnica, Parecag, Uršna sela, Krčevina pri Vurbergu and Brdinje. The few jobs located in such settlements are held by farmers or independent entrepreneurs, while the vast majority commute daily to urban centers at varying distances from their place of residence. Zgornja Besnica and Spodnja Besnica are under the strong influences of Kranj and Ljubljana, Parecag is influenced by coastal towns, Uršna sela by Novo mesto, Krčevina pri Vurbergu by Maribor and Ptuj, Brdinje by Ravne na Koroškem. All the settlements cited are in regions with strong suburbanization and second homes, cottages and other types of permanent and seasonal residence. A process of continuing expansion of exclusively residential areas and accompanying infrastructure is expected in these settlements.

The structure of jobs with respect the typology of settlements (Table 4) confirms that central Type I settlements on average have companies with a relatively large number of employed. In contrast, in Type III settlements, businesses with fewer than four employees predominate. We can also conclude that independent entrepreneurs and small companies predominate in these settlements, while the economic profile of Type I settlements is shaped by companies with a relatively large number of jobs.

Table 4: The share of companies and the share of jobs according to the size groups of companies - by settlement in 2002 (AJPES 2002).

\begin{tabular}{|c|c|c|c|c|c|c|c|c|c|c|}
\hline \multicolumn{6}{|c|}{ share of companies } & \multicolumn{5}{|c|}{ share of jobs (estimate) } \\
\hline & $\begin{array}{c}1 \text { to } 4 \\
\text { employees }\end{array}$ & 5 to 19 & 20 to 99 & $100+$ & total & $\begin{array}{c}1 \text { to } 4 \\
\text { employees }\end{array}$ & 5 to 19 & 20 to 99 & $100+$ & total \\
\hline Type I & 78.8 & 13.1 & 6.6 & 1.5 & 100 & 5.4 & 9 & 21.6 & 64 & 100 \\
\hline Type ॥ & 84.2 & 10.5 & 2.6 & 2.6 & 100 & 12 & 12.3 & 22.9 & 52.8 & 100 \\
\hline Type III & 93.6 & 5.8 & 0.6 & 0 & 100 & 57.5 & 30.2 & 12.3 & 0 & 100 \\
\hline total & 86.3 & 9.4 & 3.1 & 1.2 & 100 & 11.9 & 11.8 & 21.1 & 55.2 & 100 \\
\hline
\end{tabular}

The above-mentioned socioeconomic types of rural settlements can be connected with changes in land use between 1992 and 2005. In all the different socioeconomic types of settlements the largest number of new construction areas belonged to the category of "individual housing construction «. In settlements of the first type, there was also an above average increase in non-residential construction, since these are central settlements with well developed non-residential functions as well, such as supply, production, recreation, and others (Table 5). In settlements of the second type, changes in non-residential use of built-up areas were already fewer $(30.1 \%$ of the settled part of the settlement), and in Type III settlements, changes were very low $(6.6 \%$ of the settled part of the settlement). Individual housing construction grew strongly in settlements of the third type, in densely settled areas as well as areas with dispersed settlement (87 and $84 \%)$. 
Table 5: Newly constructed built-up areas in the period from 1992 to 2005 by type of settlement.

\begin{tabular}{|c|c|c|c|c|c|c|c|c|c|c|}
\hline & $\begin{array}{l}\text { construction } \\
\text { of individual } \\
\text { houses }\end{array}$ & $\begin{array}{l}\text { construction } \\
\text { of apartment } \\
\text { buildings }\end{array}$ & $\begin{array}{l}\text { mixed } \\
\text { (residential and } \\
\text { non-residential) }\end{array}$ & $\begin{array}{l}\text { non- } \\
\text { residential }\end{array}$ & total & $\begin{array}{l}\text { construction } \\
\text { of individual } \\
\text { houses }\end{array}$ & $\begin{array}{l}\text { construction } \\
\text { of apartment } \\
\text { buildings }\end{array}$ & $\begin{array}{l}\text { mixed } \\
\text { (residential and } \\
\text { non-residential) }\end{array}$ & $\begin{array}{l}\text { non- } \\
\text { residential }\end{array}$ & total \\
\hline $\begin{array}{l}\text { in densely settlec } \\
\text { areas of the } \\
\text { settlement }\end{array}$ & $m^{2}$ & $m^{2}$ & $\mathrm{~m}^{2}$ & $\mathrm{~m}^{2}$ & $m^{2}$ & $\%$ & $\%$ & $\%$ & $\%$ & $\%$ \\
\hline $\begin{array}{l} \\
\text { II } \\
\text { III } \\
\text { all settlements }\end{array}$ & $\begin{array}{l}21667 \\
43103 \\
17977 \\
82747 \\
\end{array}$ & $\begin{array}{r}245 \\
1916 \\
0 \\
2161 \\
\end{array}$ & $\begin{array}{l}2038 \\
3507 \\
2962 \\
8507 \\
\end{array}$ & $\begin{array}{r}11983 \\
14267 \\
2938 \\
29188 \\
\end{array}$ & $\begin{array}{r}35933 \\
62793 \\
23877 \\
122603 \\
\end{array}$ & $\begin{array}{l}60.3 \\
68.6 \\
75.3 \\
67.5 \\
\end{array}$ & $\begin{array}{l}0.7 \\
3.1 \\
0 \\
1.8 \\
\end{array}$ & $\begin{array}{r}5.7 \\
5.6 \\
12.4 \\
6.9 \\
\end{array}$ & $\begin{array}{l}33.3 \\
22.7 \\
12.3 \\
23.8 \\
\end{array}$ & $\begin{array}{l}100 \\
100 \\
100 \\
100 \\
\end{array}$ \\
\hline $\begin{array}{l}\text { in dispersedly } \\
\text { settled areas of } \\
\text { the settlement }\end{array}$ & $\mathrm{m}^{2}$ & $\mathrm{~m}^{2}$ & $\mathrm{~m}^{2}$ & $\mathrm{~m}^{2}$ & $\mathrm{~m}^{2}$ & $\%$ & $\%$ & $\%$ & $\%$ & $\%$ \\
\hline $\begin{array}{l} \\
\text { II } \\
\text { III } \\
\text { all settlements }\end{array}$ & $\begin{array}{r}3700 \\
6405 \\
64255 \\
74360\end{array}$ & $\begin{array}{l}0 \\
0 \\
0 \\
0\end{array}$ & $\begin{array}{r}322 \\
0 \\
5863 \\
6185\end{array}$ & $\begin{array}{r}3878 \\
9392 \\
3446 \\
16716 \\
\end{array}$ & $\begin{array}{r}7900 \\
15797 \\
73564 \\
97261\end{array}$ & $\begin{array}{l}46.8 \\
40.5 \\
87.3 \\
76.5\end{array}$ & $\begin{array}{l}0 \\
0 \\
0 \\
0\end{array}$ & $\begin{array}{l}4.1 \\
0 \\
8 \\
6.4\end{array}$ & $\begin{array}{r}49.1 \\
59.5 \\
4.7 \\
17.2\end{array}$ & $\begin{array}{l}100 \\
100 \\
100 \\
100\end{array}$ \\
\hline $\begin{array}{l}\text { in entire } \\
\text { settled area of } \\
\text { settlements }\end{array}$ & $\mathrm{m}^{2}$ & $\mathrm{~m}^{2}$ & $\mathrm{~m}^{2}$ & $\mathrm{~m}^{2}$ & $\mathrm{~m}^{2}$ & $\%$ & $\%$ & $\%$ & $\%$ & $\%$ \\
\hline $\begin{array}{l} \\
\text { II } \\
\text { III } \\
\text { all settlements }\end{array}$ & $\begin{array}{r}25367 \\
49508 \\
82232 \\
157107\end{array}$ & $\begin{array}{r}245 \\
1916 \\
0 \\
2161\end{array}$ & $\begin{array}{r}2360 \\
3507 \\
8825 \\
14692\end{array}$ & $\begin{array}{r}15861 \\
23659 \\
6384 \\
45904\end{array}$ & $\begin{array}{r}43833 \\
78590 \\
97441 \\
219864\end{array}$ & $\begin{array}{l}57.9 \\
63 \\
84.4 \\
71.5\end{array}$ & $\begin{array}{l}0.6 \\
2.4 \\
0 \\
1\end{array}$ & $\begin{array}{l}5.4 \\
4.5 \\
9.1 \\
6.7\end{array}$ & $\begin{array}{r}36.2 \\
30.1 \\
6.6 \\
20.9\end{array}$ & $\begin{array}{l}100 \\
100 \\
100 \\
100\end{array}$ \\
\hline
\end{tabular}


If we compare the indexes of change according to type of settlement (Table 6), we note that the greatest growth in built-up areas occurred in Type II settlements (index 109.7) and the third type (index 109). In both types, areas of new construction grew mainly in parts with more dispersed settlement. The more central Type I settlements have indexes of change of individual areas that are both lower and more evenly distributed with respect to residential and non-residential construction.

Table 6: Index of change in the areas of individual types of built-up areas in the period 2005/1992 by type of settlement.

\begin{tabular}{|c|c|c|c|c|c|}
\hline & $\begin{array}{l}\text { construction of } \\
\text { individual houses }\end{array}$ & $\begin{array}{c}\text { construction of } \\
\text { apartment buildings }\end{array}$ & $\begin{array}{l}\text { mixed (residential } \\
\text { and non-residential) }\end{array}$ & non-residential & total \\
\hline \multicolumn{6}{|c|}{ for densely settled areas of settlements } \\
\hline I & 105.4 & 101.6 & 104.2 & 106 & 105.4 \\
\hline$\|$ & 109 & 266.6 & 107.3 & 106.9 & 108.5 \\
\hline III & 104.2 & 100 & 106.5 & 108.3 & 104.7 \\
\hline all settlements & 106.3 & 110.6 & 106 & 106.6 & 106.4 \\
\hline \multicolumn{6}{|c|}{ for dispersedly settled areas of settlements } \\
\hline I & 108 & - & 105.8 & 105 & 106.1 \\
\hline$\|$ & 127.5 & - & 100 & 120.1 & 121.7 \\
\hline III & 113.5 & 100 & 116.5 & 105.8 & 112.9 \\
\hline all settlements & 113.6 & 100 & 114.1 & 109.1 & 112.6 \\
\hline \multicolumn{6}{|c|}{ for entire settled area of settlements } \\
\hline I & 105.7 & 101.6 & 104.4 & 105.7 & 105.5 \\
\hline$\|$ & 109.9 & 266.6 & 106.9 & 109.3 & 109.7 \\
\hline III & 109.1 & 100 & 110.9 & 106.7 & 109 \\
\hline all settlements & 108.5 & 110 & 107.9 & 107.3 & 108.2 \\
\hline
\end{tabular}

To summarize - in the period from 1992 to 2005 the greatest absolute growth was shown by built-up areas in Type III settlements, where the process of suburbanization is most active $\left(97,500 \mathrm{~m}^{2}\right)$, while somewhat lower growth was registered by Type II settlements $\left(78,600 \mathrm{~m}^{2}\right)$ and lowest of all by Type I settlements $\left(43,800 \mathrm{~m}^{2}\right)$. Areas of new construction showing greatest absolute growth were located in densely settled parts of settlements, except in Type III settlements, where areas of new construction were greater in parts with dispersedly settled parts.

A comparison of the relative values (indexes of change) shows that Type I settlements showed the highest growth in non-residential and individual housing construction (both indexes 105.7), while Type II settlements showed the highest growth in mixed construction (index 109.9). The index of change indicates that in all types of settlements, construction in dispersedly settled areas grew more rapidly than in densely settled areas.

These indicators of change in land use indicate that Type I settlements are growing more slowly since they have already taken the shape of »rural urbanized settlements« (Ravbar 1998). Type II settlements are more dependent on larger towns nearby, and in fact represent the suburban zone of these towns, while Type III settlements are rapidly growing rural settlements which have been affected by urbanization in the modern "form of settlements with less dense settlement«, or so-called suburbanized settlements.

\section{Land use and density of jobs}

In this part of the analysis we show the areas which are intended for certain types of activities and calculate the density of jobs for each activity per hectare by settlement. The purpose of the analysis is to provide information on some basic developmental trends in Slovene rural settlements with respect to employment, and examine differences between the types of rural settlements captured by the expert sample.

In analyzing the areas devoted to certain types of activities, we used a classification based on the Unified Classification of Activities (UCA). For the purposes of our analysis we combined these activities into eight groups, as shown in Table 7. 
Table 7: Classification of activities.

\begin{tabular}{lll}
\hline code for activity & activity according to UCA & aroups of activities in our analysis \\
\hline A & agriculture, hunting and forestry & agricultural activities \\
B & fishing and fishing-service activities & \\
\cline { 2 - 2 } C & mining & manufacturing \\
D & electricity, gas and water supply & \\
E & construction & construction \\
F & trade & trade \\
G & hotels and restaurants & hotels and restaurants \\
H & transport, storage and communications & transport \\
I & public administration and defense; compulsory social security & public activities \\
L & education & \\
M & health and social work & other service activities \\
N & financial intermediation & \\
K & real estate, renting and business activities & \\
Other community, social and personal service activities &
\end{tabular}

In the analysis of jobs, their grouping, and calculations with respect to areas devoted to certain types of activities, some problems arose due to the differing methodologies used by various sources of data. (the 2002 population census, AJPES and field work). Some generalizations, corrections, and frequently also estimates were required:

- the methodology for the determination of the group "public activities« in areas could not be completely followed in determining jobs by groups of activities from the 2002 population census (SURS); the activities public hygiene and culture were included in public activities when calculating the area, but the census methodology or rather the accessible published census data classify these as »other activities«; it is our view that jobs from these groups are not as common in rural areas as in urban settlements (this is true also of the former municipal companies and their successors, which are for the most part concentrated in cities or centers of administrative units) and that due to this the calculation of the density of jobs is not significantly different;

- due to privacy protection rules, we did not have access to data on private farmers and farms or their area, which regardless of the urbanized nature of the settlements treated still represent $8.4 \%$ of the population employed in the settlement (2002 census, SURS); for this reason, the density of jobs in agricultural activities could not be calculated;

- There is a three-year difference between data collected from field work and that from the census; for this reason in some cases it happens that areas for activities exist for which the census does not record any employees, and vice versa; in all such cases the density of jobs cited in Table 8 is 0 ;

- in some instances business entities (we took into consideration only companies of various types which have jobs) or their affiliates or branch offices are listed in the AJPES source as being in settlements where the company has its official headquarters, but not in the settlements where the economic activities actually take place; wherever possible, we adjusted this data through field work.

Because in the introductory and all other tables the built-up areas devoted to economic activities are shown in the manner explained in the methodological introduction on the inclusion of data on buildings from aerial photos and orthophotos, it is necessary to take into account that the areas and the density of jobs would be somewhat lower if shown based on data for parceled lots. From the analysis of density we excluded areas or buildings with activities such as societies, associations, sports and other clubs, hunting groups, religious groups etc., since these are not a source of employment and most frequently their headquarters are located in residential houses.

Table 8 shows the density of jobs per ha of area for a particular activity and settlement. Results in the table require some additional explanation:

- due to the problem of the inaccessibility of data on areas and jobs on private farms, we excluded the calculation for agricultural and similar activities (fisheries, forestry), since the degree of estimation from other sources was too high; in this way, the area taken up by the hog farm in the settlement of Ihan and the area devoted to economic activities of the agricultural cooperative in Velike Lašče were excluded, 
Table 8: Density of jobs (per ha) according to type of economic activity (with respect to area devoted to the activity), farming activities excluded, by settlement in 2005.

\begin{tabular}{lcccccccc}
\hline & manufacturing & construction & trade & $\begin{array}{c}\text { hotels and } \\
\text { restaurants }\end{array}$ & transport & $\begin{array}{c}\text { public } \\
\text { activities }\end{array}$ & $\begin{array}{c}\text { other service } \\
\text { activities }\end{array}$ & total \\
\hline & jobs/ha & jobs/ha & jobs/ha & jobs/ha & jobs/ha & jobs/ha & jobs/ha & jobs/ha \\
\hline Spodnja Besnica and & & & & & & & & \\
Zgornja Besnica & 20.09 & 21.93 & 16.42 & 84.99 & 34.42 & 2.81 & 44.13 & 20.6 \\
Ihan & 21.38 & 15.94 & 8.55 & 29.67 & 28.86 & 11.01 & 54.27 & 13.17 \\
Brdinje & 47.15 & 55.33 & 12 & 0 & 0 & 0 & 39.17 & 35.59 \\
Lipovci & 37.72 & 26 & 42.6 & 19.05 & 13.79 & 9.64 & 9.44 & 24.25 \\
Krčevina pri Vurbergu & 26.4 & 35.43 & 10.78 & 87.72 & 43.9 & 44.61 & 0 & 41.16 \\
Uršna sela & 40.35 & 19.55 & 83.75 & 0 & 14.48 & 7.24 & 15.22 & 24.88 \\
Žužemberk & 1653.08 & 38.55 & 106.22 & 245.9 & 83.91 & 47.01 & 21.57 & 81.68 \\
Velike Lašče & 12.44 & 48.47 & 24.23 & 53.19 & 43.57 & 49.92 & 52.32 & 31.29 \\
Lož and Stari trg & & & & & & & & \\
pri Ložu & 146.11 & 23.05 & 155.04 & 65.86 & 47.2 & 26.53 & 104.17 & 72.62 \\
Parecag & 91.3 & 63.43 & 15.92 & 20.98 & 58.48 & 63.05 & 130.51 & 32.87 \\
Križ and Šepulje & 107.2 & 21.84 & 24.99 & 26.5 & 29.04 & 12.72 & 24.62 & 51.33 \\
all settlements total & 104.36 & 34.61 & 31.32 & 41.87 & 42.52 & 26.8 & 39.74 & 47.52 \\
\hline
\end{tabular}

since both belong in the field of activities of agriculture; both differ substantially from family farms and in the case of Ihan it is an activity which is similar to manufacturing and in the case of Velike Lašče trade activities. Including the area and jobs of both these activities, which would be more realistic, would mean that the total density of jobs in the settlement of Ihan would increase by a factor of 2 (to about 25 jobs per ha), and in Velike Lašče by about a fourth (to about 40 jobs per ha);

- in the table on density of jobs in manufacturing an unusually high value for Žužemberk is listed - 1653; the values in the other settlements range from 12 to 146, the average for all settlements is 104; the cause for this is that at the address of the industrial enterprise there are also numerous other activities which do not belong in the category of manufacturing, and thus the area is methodologically included in areas with a number of activities; the value is, if we take into account the value for Lož-Stari trg with a similar economic composition, at least ten times too high; there is no influence of this calculation problem on the total density of jobs in the settlement;

- the density of jobs for transport, construction, and other services is too high, since these are most often independent entrepreneurs (truckers, builders, owner-operators of heavy construction machinery, those who are self-employed in private medicine, law, financial advising, independent cultural workers), where the business premises at home rarely consist of much more than an expanded parking lot for vehicles or modified or adapted residential houses; these are frequently only the headquarters of the company while employees carry out most of their work outside the settlement. Because a number of small companies from the groups mentioned are often in small settlements with a dispersed settlement pattern, the data on the density of jobs (in comparison with central settlements and centers of employment) is in reality lower. This is especially true of the settlements Krčevina pri Vurbergu, home to a number of trucking companies, and Brdinje, where there are a number of independent entrepreneurs in the field of construction.

If in addition to the data from the table we take into account the corrections noted above, we arrive at the following conclusions regarding the density of jobs:

- the greatest density of jobs is in manufacturing (even taking into account the correction for Žužemberk, there are still 92 jobs/ha);

- manufacturing is followed by hotels and restaurants, and trade;

- the values for the density of jobs in other groups of activities are lower, for the reasons outlined above, or in other words, numerous companies do not require special areas in the settlement for their operations and hence the activities of their employees are not as tied to the region of the settlement;

- the greatest density of jobs is in settlements with a large or relatively large number of medium-sized enterprises (Žužemberk, Lož-Stari trg, Križ-Šepulje and Velike Lašče);

- lower densities of jobs are found in dispersedly settled smaller settlements with a relatively small number of central activities and a relatively large number of independent entrepreneurs or small businesses. 


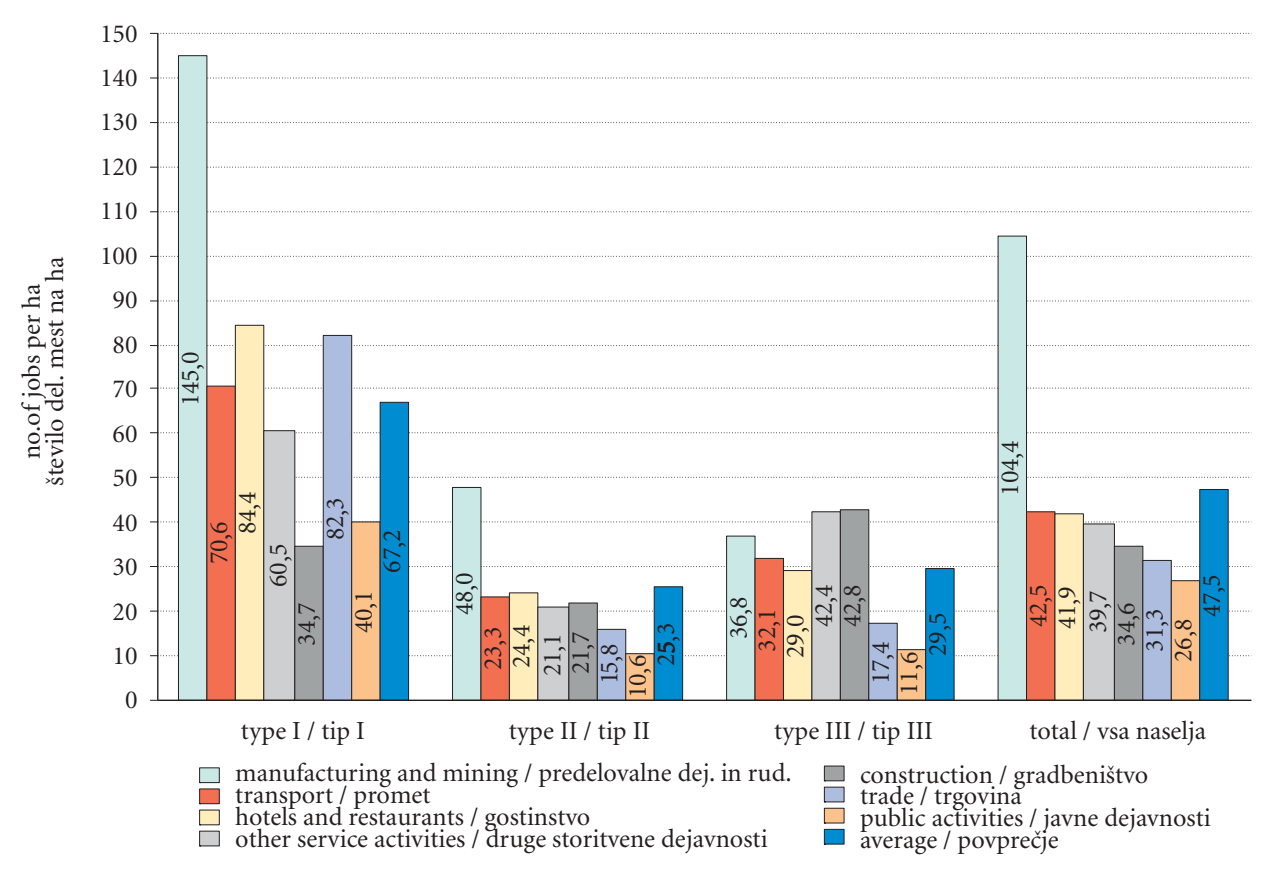

Figure 18: Density of jobs by activity (excluding agriculture) and by type of settlement in 2005.

Table 9 and Figure 18 show the density of jobs by economic activity for groups of settlements as presented in the definition of the expert sample of settlements treated: Type I - central settlements (Žužemberk, Lož-Stari trg pri Ložu, Velike Lašče), Type II - employment centers (Lipovci, Ihan, Križ-Šepulje) and Type III - other settlements (Spodnja Besnica and Zgornja Besnica, Brdinje, Krčevina pri Vurbergu, Uršna sela, Parecag).

Table 9: Density of jobs by activity (with respect to the area devoted to the activity), excluding agricultural activities (2005).

\begin{tabular}{lcccccccc}
\hline & $\begin{array}{c}\text { manufacturing } \\
\text { and mining }\end{array}$ & construction & trade & $\begin{array}{c}\text { hotels and } \\
\text { restaurants }\end{array}$ & transport & $\begin{array}{c}\text { public } \\
\text { activities }\end{array}$ & $\begin{array}{c}\text { other } \\
\text { service activities }\end{array}$ & total \\
\hline & jobs/ha & jobs/ha & jobs/ha & jobs/ha & jobs/ha & jobs/ha & jobs/ha & jobs/ha \\
\hline Type I & 144.97 & 34.66 & 82.28 & 84.43 & 70.64 & 40.09 & 60.51 & 67.22 \\
Type II & 47.98 & 21.67 & 15.78 & 24.38 & 23.29 & 10.58 & 21.1 & 25.31 \\
Type III & 36.77 & 42.83 & 17.37 & 29.03 & 32.14 & 11.57 & 42.36 & 29.47 \\
all settlements & 104.36 & 34.61 & 31.32 & 41.87 & 42.52 & 26.8 & 39.74 & 47.52 \\
\hline
\end{tabular}

Grouping of data by type of settlement allows us to make some reasonable generalizations about the density of jobs. Municipal centers (central settlements) show the highest density of total jobs and the highest density of jobs in most of the activities, especially manufacturing. Type III settlements have a higher density of total jobs and jobs in most activities than Type II, a seeming paradox. This is a consequence of the calculations of density for construction, transport, and other services, which for the reasons mentioned above are too high; it is in these groups of activities that the differences between Type II settlements and Type III settlements, as shown in Table 9, are greatest.

Companies (and other business entities providing jobs) in the settlements studied were for the most part small, with a low number of employees. $96 \%$ of companies had fewer than 20 employees, and $86 \%$ had fewer than five. All the jobs in the settlements of Spodnja Besnica and Zgornja Besnica, Brdinje, Uršna sela 


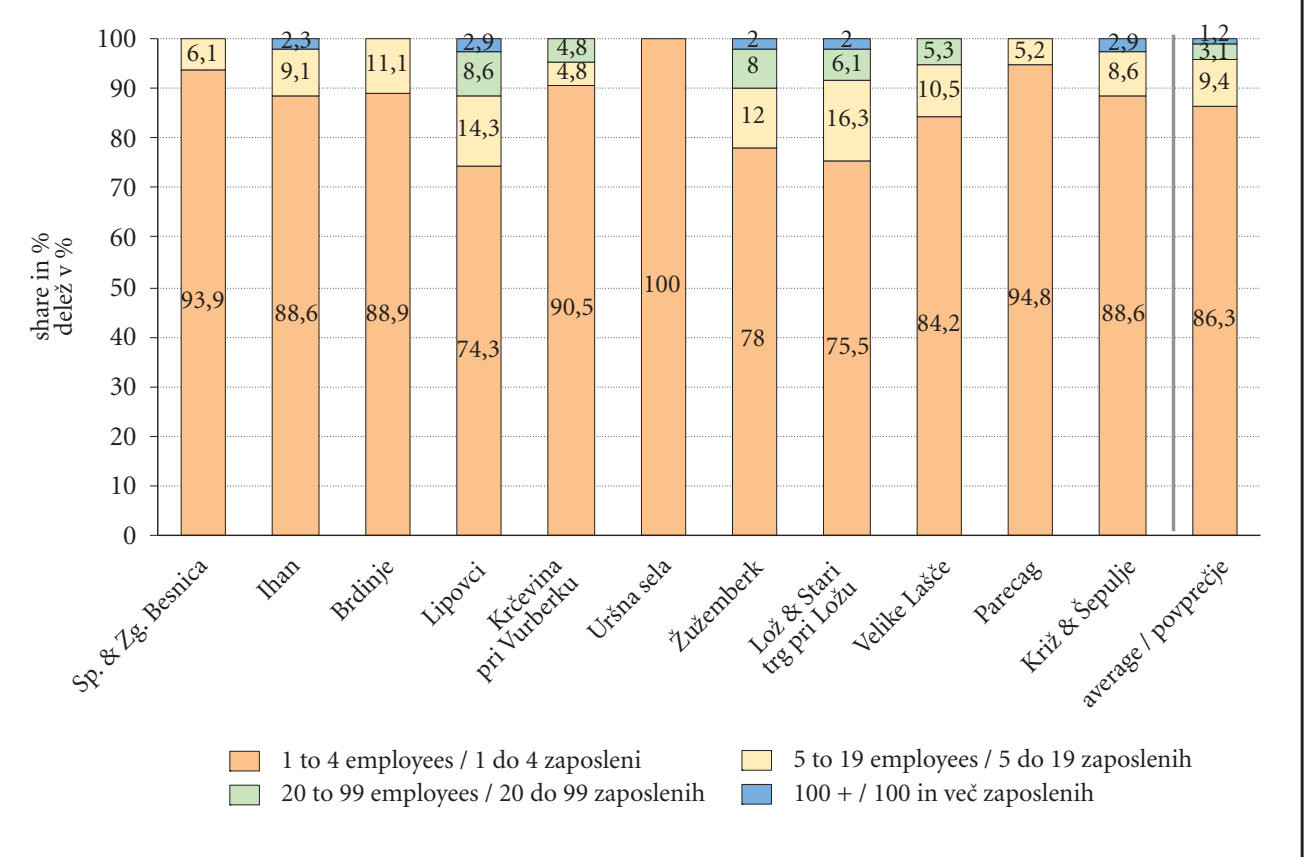

Figure 19: The structure of companies by size (number of jobs) in \% - by settlement, data from 2002 (AJPES).

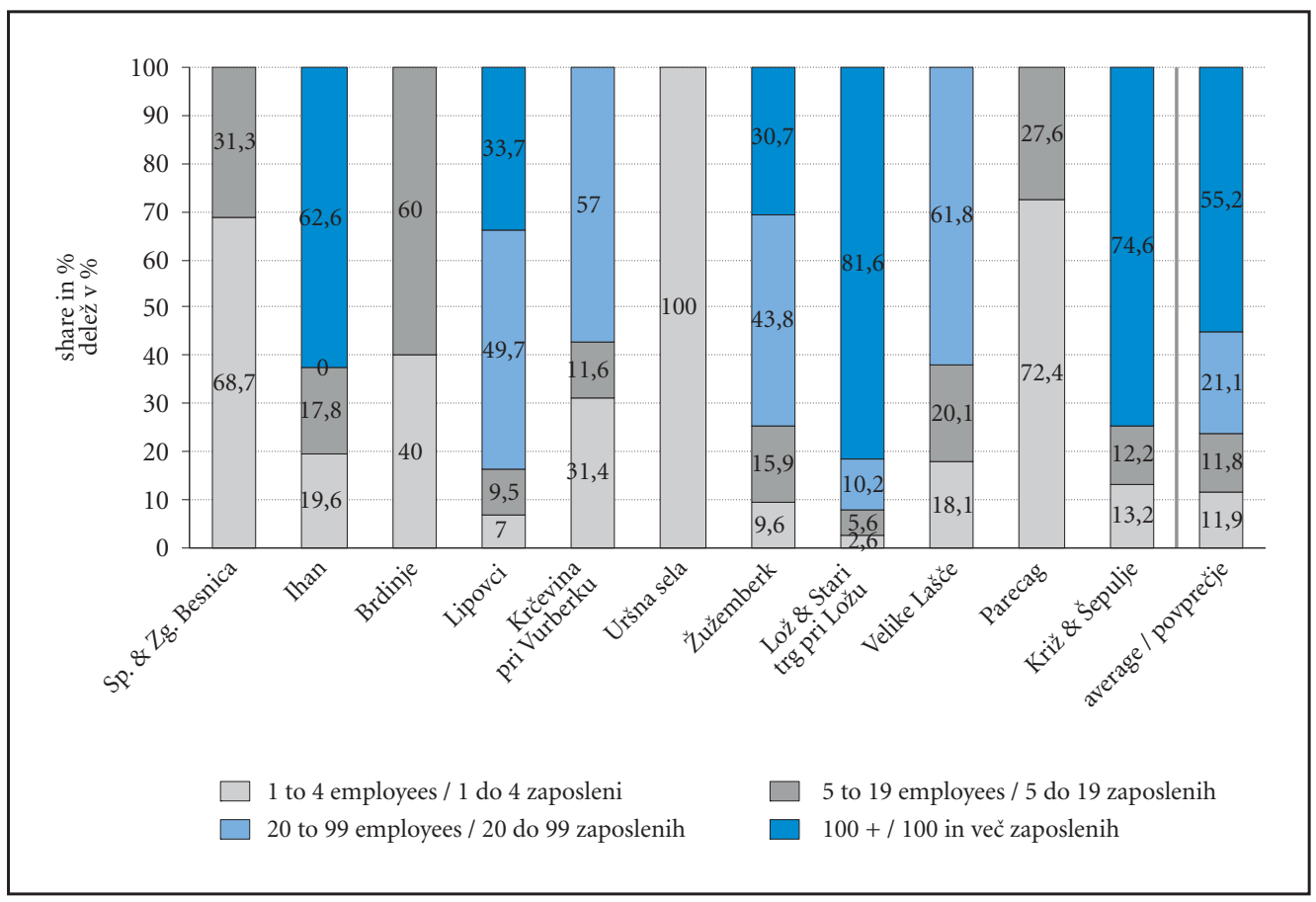

Figure 20: The share of jobs with respect to size of company - by settlement, data from 2002 (AJPES). 
Table 10: Areas of new construction in the period from 1992 to 2005 by settlement.

\begin{tabular}{|c|c|c|c|c|c|c|c|c|c|c|c|}
\hline & name of settlement & $\begin{array}{l}\text { construction } \\
\text { of individual } \\
\text { houses }\end{array}$ & $\begin{array}{l}\text { construction } \\
\text { of apartment } \\
\text { buildings }\end{array}$ & $\begin{array}{l}\text { mixed } \\
\text { residential } \\
\text { and non- } \\
\text { residential }\end{array}$ & $\begin{array}{l}\text { non- } \\
\text { residential }\end{array}$ & total & $\begin{array}{l}\text { construction } \\
\text { of individual } \\
\text { houses }\end{array}$ & $\begin{array}{l}\text { construction } \\
\text { of apt. } \\
\text { buildings }\end{array}$ & $\begin{array}{l}\text { mixed } \\
\text { residential } \\
\text { and non- } \\
\text { residential }\end{array}$ & $\begin{array}{l}\text { non- } \\
\text { residential }\end{array}$ & total \\
\hline A & DENSELY SETTLED AREA OF SETTLEMENT & $\mathrm{m}^{2}$ & $\mathrm{~m}^{2}$ & $\mathrm{~m}^{2}$ & $\mathrm{~m}^{2}$ & $\mathrm{~m}^{2}$ & share in \% & share in $\%$ & share in \% & share in \% & share in \% \\
\hline 1 & Spodnja Besnica and Zgornja Besnica & 8658 & 0 & 763 & 1127 & 10548 & 82.1 & 0 & 7.2 & 10.7 & 100 \\
\hline 2 & Ihan & 4424 & 1916 & 1905 & 570 & 8815 & 50.2 & 21.7 & 21.6 & 6.5 & 100 \\
\hline 3 & Brdinje & 1236 & 0 & 85 & 0 & 1321 & 93.6 & 0 & 6.4 & 0 & 100 \\
\hline 4 & Lipovci & 14045 & 0 & 0 & 7216 & 21261 & 66.1 & 0 & 0 & 33.9 & 100 \\
\hline 5 & Krčevina pri Vurbergu & 310 & 0 & 0 & 0 & 310 & 100 & 0 & 0 & 0 & 100 \\
\hline 6 & Uršna Sela & 5570 & 0 & 182 & 215 & 5967 & 93.3 & 0 & 3.1 & 3.6 & 100 \\
\hline 7 & Žužemberk & 9220 & 0 & 1207 & 4372 & 14799 & 62.3 & 0 & 8.2 & 29.5 & 100 \\
\hline 8 & Velike Lašče & 6856 & 0 & 387 & 5130 & 12373 & 55.4 & 0 & 3.1 & 41.5 & 100 \\
\hline 9 & Lož and Stari trg pri Ložu & 5591 & 245 & 444 & 2481 & 8761 & 63.8 & 2.8 & 5.1 & 28.3 & 100 \\
\hline 10 & Parecag & 2203 & 0 & 1932 & 1596 & 5731 & 38.4 & 0 & 33.7 & 27.8 & 100 \\
\hline 11 & Križ and Šepulje & 24634 & 0 & 1602 & 6481 & 32717 & 75.3 & 0 & 4.9 & 19.8 & 100 \\
\hline$\sum$ & total & 82747 & 2161 & 8507 & 29188 & 122603 & 67.5 & 1.8 & 6.9 & 23.8 & 100 \\
\hline B & DISPERSEDLY SETTLED AREA OF SETTLEMENT & $m^{2}$ & $\mathrm{~m}^{2}$ & $\mathrm{~m}^{2}$ & $\mathrm{~m}^{2}$ & $\mathrm{~m}^{2}$ & share in \% & share in $\%$ & share in \% & share in $\%$ & share in $\%$ \\
\hline 1 & Spodnja Besniac and Zgornja Besnica & 8442 & 0 & 1003 & 917 & 10362 & 81.5 & 0 & 9.7 & 8.8 & 100 \\
\hline 2 & Ihan & 1146 & 0 & 0 & 3916 & 5062 & 22.6 & 0 & 0 & 77.4 & 100 \\
\hline 3 & Brdinje & 15940 & 0 & 644 & 1299 & 17883 & 89.1 & 0 & 3.6 & 7.3 & 100 \\
\hline 4 & Lipovci & 6 & 0 & 0 & 5205 & 5211 & 0.1 & 0 & 0 & 99.9 & 100 \\
\hline 5 & Krčevina pri Vurbergu & 28345 & 0 & 2147 & 882 & 31374 & 90.3 & 0 & 6.8 & 2.8 & 100 \\
\hline 6 & Uršna Sela & 8389 & 0 & 1398 & 348 & 10135 & 82.8 & 0 & 13.8 & 3.4 & 100 \\
\hline 7 & Žužemberk & 1501 & 0 & 0 & 818 & 2319 & 64.7 & 0 & 0 & 35.3 & 100 \\
\hline 8 & Velike Lašče & 1906 & 0 & 322 & 2191 & 4419 & 43.1 & 0 & 7.3 & 49.6 & 100 \\
\hline 9 & Lož and Stari trg pri Ložu & 293 & 0 & 0 & 869 & 1162 & 25.2 & 0 & 0 & 74.8 & 100 \\
\hline 10 & Parecag & 3139 & 0 & 671 & 0 & 3810 & 82.4 & 0 & 17.6 & 0 & 100 \\
\hline 11 & Križ in Šepulje & 5253 & 0 & 0 & 271 & 5524 & 95.1 & 0 & 0 & 4.9 & 100 \\
\hline$\Sigma$ & total & 74360 & 0 & 6185 & 16716 & 97261 & 76.5 & 0 & 6.4 & 17.2 & 100 \\
\hline $\mathrm{C}$ & TOTAL SETTLED AREA OF SETTLEMENT & $\mathrm{m}^{2}$ & $\mathrm{~m}^{2}$ & $\mathrm{~m}^{2}$ & $\mathrm{~m}^{2}$ & $\mathrm{~m}^{2}$ & share in $\%$ & share in \% & share in \% & share in \% & share in $\%$ \\
\hline 1 & Spodnja Besnica and Zgornja Besnica & 17100 & 0 & 1766 & 2044 & 20910 & 81.8 & 0 & 8.4 & 9.8 & 100 \\
\hline 2 & Ihan & 5570 & 1916 & 1905 & 4486 & 13877 & 40.1 & 13.8 & 13.7 & 32.3 & 100 \\
\hline 3 & Brdinje & 17176 & 0 & 729 & 1299 & 19204 & 89.4 & 0 & 3.8 & 6.8 & 100 \\
\hline 4 & Lipovci & 14051 & 0 & 0 & 12421 & 26472 & 53.1 & 0 & 0 & 46.9 & 100 \\
\hline 5 & Krčevina pri Vurbergu & 28655 & 0 & 2147 & 882 & 31684 & 90.4 & 0 & 6.8 & 2.8 & 100 \\
\hline 6 & Ǔšna Sela & 13959 & 0 & 1580 & 563 & 16102 & 86.7 & 0 & 9.8 & 3.5 & 100 \\
\hline 7 & Žužemberk & 10721 & 0 & 1207 & 5190 & 17118 & 62.6 & 0 & 7.1 & 30.3 & 100 \\
\hline 8 & Velike Lašče & 8762 & 0 & 709 & 7321 & 16792 & 52.2 & 0 & 4.2 & 43.6 & 100 \\
\hline 9 & Lož and Stari trg pri Ložu & 5884 & 245 & 444 & 3350 & 9923 & 59.3 & 2.5 & 4.5 & 33.8 & 100 \\
\hline 10 & Parecag & 5342 & 0 & 2603 & 1596 & 9541 & 56 & 0 & 27.3 & 16.7 & 100 \\
\hline 11 & Križ and Šepulje & 29887 & 0 & 1602 & 6752 & 38241 & 78.2 & 0 & 4.2 & 17.7 & 100 \\
\hline$\sum$ & total & 157107 & 2161 & 14692 & 45904 & 219864 & 71.5 & 1 & 6.7 & 20.9 & 100 \\
\hline
\end{tabular}


and Parecag were in companies with fewer than 20 employees. In the remaining settlements the majority of jobs were in companies with fewer than 20 employees, most (over two-thirds) of them in the central settlements and employment centers of Lož-Stari trg, Lipovci, Križ-Šepulje and Žužemberk (Figures 19 and 20). The greatest numbers of small companies were to be found in the fields of construction, transport, trade and other services. A concentration of such companies, and of the jobs within them, was typical of smaller settlements with a dispersed settlement pattern, which in recent years have grown as a result of the in-migration of residents from nearby urban settlements.

\section{Changes in land use in the period from 1992 to 2005}

In the context of the suburbanization process in Slovenia, the migration of population from cities to rural areas is also accompanied by the relocation of some economic activities to less expensive rural locations. We thus see the beginnings of a mixing of uses of rural land. Thus far large concentrations of jobs are rare, but the process is reflected in the lower degree of population decrease in the vicinity of these settlements (Kladnik, Ravbar 2003).

In the period from 1992 to 2005 the built-up areas in all eleven settlements increased by $8.2 \%$ or 22 ha (Tables 10 in 11). Most of the new areas, $71 \%$, were devoted to housing construction, while $21 \%$ was devoted to the construction of non-residential buildings. The remaining areas consist of new buildings with a mix of residential/non-residential functions. Among the various types of construction (individual houses, apartment buildings, mixed function and non-residential - buildings for economic activities and public functions, etc.) there are no significant differences in the rate of growth. The areas of the individual types increased by 7.3 to $10 \%$. The most dynamic growth was shown by construction of apartment buildings, but in this case the area affected is quite small ( 2.4 ha total, or $0.8 \%$ of built-up areas). Housing construction in general showed a somewhat higher rate of relative growth, which is directly connected to population in-migration, since many of the settlements studied typically lie in the direct gravitational hinterland of larger urban centers.

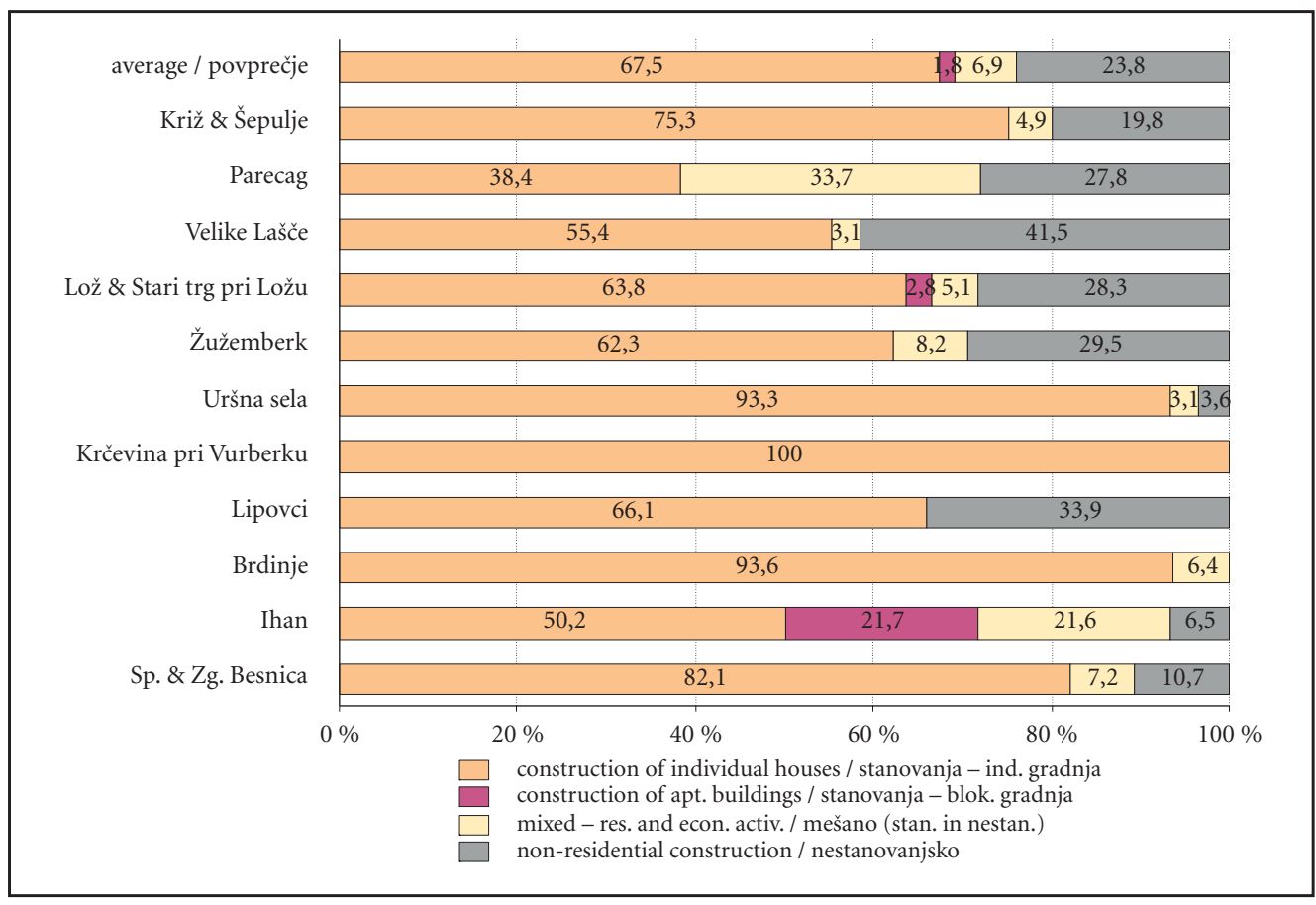

Figure 21: Structure in the period 1992-2005 of areas of new construction in densely settled areas by settlement. 
Maja Topole, David Bole, Franci Petek, Peter Repolusk, Spatial and functional changes in built-up areas in selected slovene rural ...

Table 11: Index of change in the area of different types of built-up areas in the period 2005/1992 by settlement.

\begin{tabular}{|c|c|c|c|c|c|c|}
\hline & $\begin{array}{l}\text { name of } \\
\text { settlement }\end{array}$ & $\begin{array}{l}\text { construction of } \\
\text { individual houses }\end{array}$ & $\begin{array}{l}\text { construction of } \\
\text { apartment buildings }\end{array}$ & $\begin{array}{l}\text { mixed residential } \\
\text { and non-residential }\end{array}$ & $\begin{array}{l}\text { non-residential } \\
\text { construction }\end{array}$ & total \\
\hline A & $\begin{array}{l}\text { DENSELY SETTLED AREA } \\
\text { OF SETTLEMENT }\end{array}$ & & & & & \\
\hline 1 & $\begin{array}{l}\text { Spodnja Besnica and } \\
\text { Zgornja Besnica }\end{array}$ & 103.24 & - & 104.23 & 109.93 & 103.55 \\
\hline 2 & Ihan & 106.57 & 266.61 & 111.74 & 100.4 & 103.9 \\
\hline 3 & Brdinje & 102.8 & - & 100.97 & - & 102.48 \\
\hline 4 & Lipovci & 105.09 & - & 100 & 112.56 & 106.07 \\
\hline 5 & Krčevina pri Vurbergu & 102.38 & - & - & - & 102.38 \\
\hline 6 & Uršna Sela & 107.38 & - & 105.06 & 107.09 & 107.27 \\
\hline 7 & Žužemberk & 105.43 & 100 & 106.86 & 115.11 & 106.72 \\
\hline 8 & Velike Lašče & 112.52 & 100 & 103.56 & 117.31 & 112.66 \\
\hline 9 & Lož and Stari trg pri Ložu & 103.15 & 102.64 & 102.24 & 101.77 & 102.5 \\
\hline 10 & Parecag & 109.42 & 100 & 112.75 & 107.54 & 108.97 \\
\hline 11 & Križ and Šepulje & 118.25 & - & 111.2 & 170.62 & 120.64 \\
\hline$\sum$ & total & 106.35 & 110.56 & 106 & 106.6 & 106.41 \\
\hline$B$ & $\begin{array}{l}\text { DISPERSEDLY SETTLED } \\
\text { AREA OF SETTLEMENT }\end{array}$ & & & & & \\
\hline 1 & Spodnja Besnica and & & & & & \\
\hline & Zgornja Besnica & 112.95 & - & 130.94 & 105.04 & 111.96 \\
\hline 2 & Ihan & 110.86 & - & 100 & 134.19 & 122.52 \\
\hline 3 & Brdinje & 125.71 & - & 109.38 & 300.46 & 125.31 \\
\hline 4 & Lipovci & 100.27 & - & 100 & 119.53 & 117.21 \\
\hline 5 & Krčevina pri Vurbergu & 113.37 & - & 119.11 & 105.55 & 113.12 \\
\hline 6 & Uršna Sela & 110.45 & 100 & 131.79 & 101.97 & 109.8 \\
\hline 7 & Žužemberk & 105.98 & - & 100 & 109.56 & 106.38 \\
\hline 8 & Velike Lašče & 118.93 & - & 119.21 & 128.56 & 122.76 \\
\hline 9 & Lož and Stari trg pri Ložu & 102.65 & - & 100 & 101.4 & 101.56 \\
\hline 10 & Parecag & 105.62 & 100 & 106.92 & 100 & 105.2 \\
\hline 11 & Križ and Šepulije & 149.69 & - & 100 & 103.16 & 127.5 \\
\hline$\Sigma$ & total & 113.65 & 100 & 114.12 & 109.05 & 112.53 \\
\hline $\bar{C}$ & $\begin{array}{l}\text { TOTAL SETTLED AREA } \\
\text { OF SETTLEMENT }\end{array}$ & & & & & \\
\hline 1 & $\begin{array}{l}\text { Spodnja Besnica and } \\
\text { Zgornja Besnica }\end{array}$ & 105.14 & - & 108.3 & 106.92 & 105.45 \\
\hline 2 & Ihan & 107.15 & 266.61 & 111.41 & 102.93 & 105.58 \\
\hline 3 & Brdinje & 116.18 & - & 104.65 & 300.46 & 115.5 \\
\hline 4 & Lipovci & 105.06 & - & 100 & 114.77 & 106.95 \\
\hline 5 & Krčevina pri Vurbergu & 112.73 & - & 119.11 & 105.55 & 112.56 \\
\hline 6 & Uršna Sela & 108.96 & 100 & 119.76 & 102.71 & 108.68 \\
\hline 7 & Žužemberk & 105.5 & 100 & 105.95 & 113.84 & 106.67 \\
\hline 8 & Velike Lašče & 113.51 & 100 & 105.66 & 119.62 & 114.34 \\
\hline 9 & Lož and Stari trg pri Ložu & 103.12 & 102.64 & 102.12 & 101.66 & 102.34 \\
\hline 10 & Parecag & 106.74 & 100 & 110.47 & 105.62 & 106.96 \\
\hline 11 & Križ and Šepulje & 120.53 & - & 110.51 & 138.04 & 121.41 \\
\hline$\Sigma$ & total & 108.5 & 110.02 & 107.92 & 107.32 & 108.18 \\
\hline
\end{tabular}

There are greater differences among settlements. Most intensive construction occurred in:

- settlements with population in-migration (strong residential and non-residential construction: Brdinje, Križ-Šepulje, Velike Lašče);

- in settlements with population in-migration (strong residential and mixed construction: Krčevina pri Vurbergu);

Less intensive construction occurred in:

- settlements which were affected by suburbanization and population in-migration before 1990 (Spodnja Besnica and Zgornja Besnica, Ihan); 
- settlements with signs of stagnation in demographic and economic development (Uršna sela, Lipovci) and

- settlements which are larger and have the qualities of small urban centers from which part of the population moves to smaller neighboring settlements - Lož-Stari trg and Žužemberk.

There are also pronounced differences in the characteristics of construction between the densely settled and the dispersedly settled areas within settlements. In the former, housing construction represents $67.5 \%$ of the total new construction, while in the latter this figure is $76.5 \%$. In contrast, non-residential construction represents $23.8 \%$ of new construction in densely settled areas and $17.2 \%$ in dispersedly settled areas of settlements. The share of mixed function construction is very similar for both -6.9 and $6.4 \%$.

Settlements can be divided into several groups with respect to the structure of areas of new construction and the differences between densely settled areas and dispersedly settled areas, though the differences among the groups are not pronounced (Figures 21-23):

- Lož-Stari trg, Ihan and Lipovci - here the share of housing construction in all new construction is under $65 \%$, and the share of non-residential new construction in the dispersedly settled part of the settlement is high (in relatively large production premises at the edge of the village);

- Žužemberk and Velike Lašče - the share of housing construction in all new construction is under 65\%, and the share of non-residential construction in the densely settled part of the settlement is high;

- Parecag - the share of new housing construction is $65 \%$, and the share of mixed-function construction is high in both densely and dispersedly settled parts of the settlement;

- Spodnja Besnica and Zgornja Besnica, Brdinje, Krčevina pri Vurbergu, Uršna sela - the share of housing construction in all new construction is over $80 \%$, and this kind of new construction dominates in both densely settled and dispersedly settled parts of the settlement; the shares of mixed function and non-residential construction are equal;

- Križ-Šepulje - this settlement has the most intense new construction of all the settlements treated; there is a preponderance of new housing construction.

The bulk of areas of new construction (56\%) is still in the densely settled core areas of settlements, but the dynamics of relative growth of building are greater at the edge of settlements, where the built-up areas increased by $12.5 \%$ in the period studied, while the figure for the centers of settlements is only $6.4 \%$

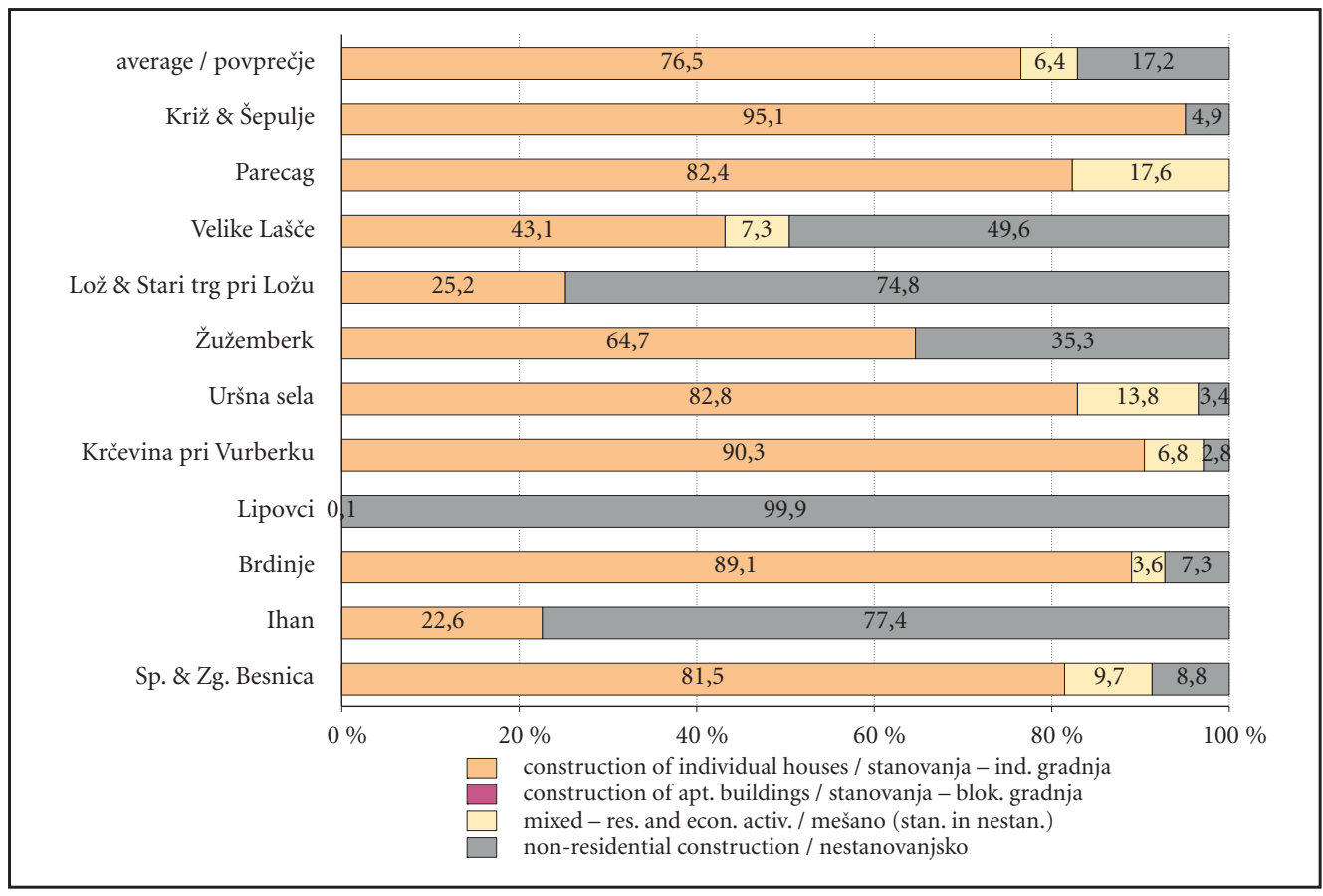

Figure 22: Structure in the period 1992-2005 of areas of new construction in dispersedly settled areas by settlement. 
Table 12: Average annual growth in individual types of built-up areas by settlement (in \%) for the period 1992/2005 and intervals within it.

\begin{tabular}{|c|c|c|c|c|c|c|c|c|c|c|c|c|c|c|c|c|}
\hline \multirow[b]{2}{*}{$A$} & \multirow{2}{*}{$\begin{array}{l}\text { name of settlement } \\
\text { DENSELY SETTLED } \\
\text { AREA OF THE } \\
\text { SETTLEMENT }\end{array}$} & \multicolumn{3}{|c|}{$\begin{array}{l}\text { construction of } \\
\text { individual houses }\end{array}$} & \multicolumn{3}{|c|}{$\begin{array}{l}\text { construction of } \\
\text { apartment buildings }\end{array}$} & \multicolumn{3}{|c|}{$\begin{array}{l}\text { mixed - residential } \\
\text { and economic activities }\end{array}$} & \multicolumn{3}{|c|}{ economic activities } & \multicolumn{3}{|c|}{ total } \\
\hline & & $\begin{array}{c}1992 / \\
1998 \\
\%\end{array}$ & $\begin{array}{c}1999 / \\
2005 \\
\%\end{array}$ & $\begin{array}{c}1992 / \\
2005 \\
\%\end{array}$ & $\begin{array}{c}1992 / \\
1998 \\
\%\end{array}$ & $\begin{array}{l}1999 / \\
2005 \\
\%\end{array}$ & $\begin{array}{c}1992 / \\
2005 \\
\%\end{array}$ & $\begin{array}{c}1992 / \\
1998 \\
\%\end{array}$ & $\begin{array}{c}1999 / \\
2005 \\
\%\end{array}$ & $\begin{array}{c}1992 / \\
2005 \\
\%\end{array}$ & $\begin{array}{c}1992 / \\
1998 \\
\%\end{array}$ & $\begin{array}{c}1999 / \\
2005 \\
\%\end{array}$ & $\begin{array}{c}1992 / \\
2005 \\
\%\end{array}$ & $\begin{array}{c}1992 / \\
1998 \\
\%\end{array}$ & $\begin{array}{c}1999 / \\
2005 \\
\%\end{array}$ & $\begin{array}{c}1992 / \\
2005 \\
\%\end{array}$ \\
\hline 1 & $\begin{array}{l}\text { Spodnja Besnica and } \\
\text { Zgornja Besnica }\end{array}$ & 0.36 & 0.17 & 0.25 & - & - & - & 0.83 & 0 & 0.32 & 1.15 & 0.47 & 0.73 & 0.42 & 0.17 & 0.27 \\
\hline 2 & Ihan & 0.93 & 0.12 & 0.49 & 17.75 & 0 & 7.83 & 1.87 & 0 & 0.86 & 0.07 & 0 & 0.03 & 0.6 & 0.04 & 0.29 \\
\hline 3 & Brdinje & 0.24 & 0 & 0.18 & - & - & - & 0.08 & 0 & 0.06 & - & - & - & 0.21 & 0 & 0.16 \\
\hline 4 & Lipovci & 0.25 & 0.46 & 0.33 & - & - & - & 0 & 0 & 0 & 0.29 & 1.55 & 0.79 & 0.24 & 0.62 & 0.39 \\
\hline 5 & Krčevina pri Vurbergu & 0 & 0.29 & 0.18 & - & - & - & - & - & - & - & - & - & 0 & 0.29 & 0.18 \\
\hline 6 & Uršna Sela & 0.75 & 0.23 & 0.55 & - & - & - & 0 & 0.99 & 0.38 & 0.86 & 0 & 0.53 & 0.72 & 0.26 & 0.54 \\
\hline 7 & Žužemberk & 0.54 & 0.32 & 0.41 & 0 & 0 & 0 & 1.34 & 0 & 0.51 & 0.87 & 1.23 & 1.09 & 0.64 & 0.42 & 0.5 \\
\hline 8 & Velike Lašče & 1.87 & 0.1 & 0.91 & 0 & 0 & 0 & 0.59 & 0 & 0.27 & 0.57 & 1.81 & 1.24 & 1.3 & 0.6 & 0.92 \\
\hline 9 & $\begin{array}{l}\text { Lož and Stari trg } \\
\text { pri Ložu }\end{array}$ & 0.47 & 0.09 & 0.24 & 0.52 & 0 & 0.2 & 0.44 & 0 & 0.17 & 0.35 & 0 & 0.14 & 0.42 & 0.05 & 0.19 \\
\hline 10 & Parecag & 1.49 & 0.2 & 0.69 & 0 & 0 & 0 & 1.84 & 0.36 & 0.93 & 1.46 & 0 & 0.56 & 1.47 & 0.16 & 0.66 \\
\hline 11 & Križ in Šepulje & 2.62 & 0.16 & 1.2 & - & - & - & 1.79 & 0 & 0.76 & 9.31 & 0 & 3.89 & 3 & 0.13 & 1.35 \\
\hline$\sum$ & total & 0.76 & 0.23 & 0.47 & 1.69 & 0 & 0.78 & 0.9 & 0.06 & 0.45 & 0.59 & 0.41 & 0.49 & 0.74 & 0.26 & 0.48 \\
\hline$B$ & $\begin{array}{l}\text { DISERSEDLY } \\
\text { SETTLED AREA } \\
\text { OF SETTLEMENT }\end{array}$ & $\begin{array}{c}1992 / \\
1998 \\
\%\end{array}$ & $\begin{array}{c}1999 / \\
2005 \\
\%\end{array}$ & $\begin{array}{c}1992 / \\
2005 \\
\%\end{array}$ & $\begin{array}{c}1992 / \\
1998 \\
\%\end{array}$ & $\begin{array}{c}1999 / \\
2005 \\
\%\end{array}$ & $\begin{array}{c}1992 / \\
2005 \\
\%\end{array}$ & $\begin{array}{c}1992 / \\
1998 \\
\%\end{array}$ & $\begin{array}{c}1999 / \\
2005 \\
\%\end{array}$ & $\begin{array}{c}1992 / \\
2005 \\
\%\end{array}$ & $\begin{array}{c}1992 / \\
1998 \\
\%\end{array}$ & $\begin{array}{c}1999 / \\
2005 \\
\%\end{array}$ & $\begin{array}{c}1992 / \\
2005 \\
\%\end{array}$ & $\begin{array}{c}1992 / \\
1998 \\
\%\end{array}$ & $\begin{array}{c}1999 / \\
2005 \\
\%\end{array}$ & $\begin{array}{c}1992 / \\
2005 \\
\%\end{array}$ \\
\hline 1 & $\begin{array}{l}\text { Spodnja Besnica and } \\
\text { Zaornia Besnica }\end{array}$ & 1.17 & 0.8 & 0.94 & _ & _ & - & 5.54 & 0 & 21 & 0.99 & 0 & 0.38 & 131 & 0.6 & 0.87 \\
\hline 2 & lhan & 0 & 1.48 & 0.8 & - & - & - & 0 & 0 & 0 & 0 & 4.29 & 2.29 & 0 & 2.94 & 1.57 \\
\hline 3 & Brdinje & 1.94 & 0.23 & 1.54 & - & - & - & 0.78 & 0 & 0.6 & 10.04 & 0 & 7.61 & 1.92 & 0.2 & 1.52 \\
\hline 4 & Lipovci & 0 & 0.05 & 0.02 & - & - & - & 0 & 0 & 0 & 0.61 & 2.08 & 1.2 & 0.54 & 1.85 & 1.06 \\
\hline 5 & Krčevina pri Vurbergu & 2.29 & 0.15 & 0.97 & - & - & - & 2.24 & 0.81 & 1.35 & 0.68 & 0.25 & 0.42 & 2.19 & 0.19 & 0.95 \\
\hline 6 & Uršna Sela & 1.04 & 0.33 & 0.77 & 0 & 0 & 0 & 1.03 & 3.95 & 2.15 & 0.24 & 0 & 0.15 & 0.9 & 0.44 & 0.72 \\
\hline 7 & Žužemberk & 0.53 & 0.4 & 0.45 & - & - & - & 0 & 0 & 0 & 0 & 1.15 & 0.7 & 0.37 & 0.54 & 0.48 \\
\hline 8 & Velike Lašče & 2.55 & 0.32 & 1.34 & - & - & - & 2.97 & 0 & 1.36 & 4.28 & 0 & 1.95 & 3.29 & 0.16 & 1.59 \\
\hline 9 & Lož and Stari trg & & & & & & & & & & & & & & & \\
\hline & pri Ložu & 0.52 & 0 & 0.2 & - & - & - & 0 & 0 & 0 & 0.28 & 0 & 0.11 & 0.31 & 0 & 0.12 \\
\hline 10 & Parecag & 0.65 & 0.28 & 0.42 & 0 & 0 & 0 & 1.35 & 0 & 0.52 & 0 & 0 & 0 & 0.67 & 0.21 & 0.39 \\
\hline 11 & Križ and Šepulje & 6.29 & 0.47 & 2.92 & - & - & - & 0 & 0 & 0 & 0.52 & 0 & 0.22 & 3.73 & 0.29 & 1.75 \\
\hline$\Sigma$ & total & 1.78 & 0.32 & 0.99 & 0 & 0 & 0 & 1.58 & 0.54 & 1.02 & 0.71 & 0.64 & 0.67 & 1.51 & 0.4 & 0.91 \\
\hline
\end{tabular}




\begin{tabular}{|c|c|c|c|c|c|c|c|c|c|c|c|c|c|c|c|c|}
\hline \multirow{2}{*}{$\bar{C}$} & \multirow{2}{*}{$\begin{array}{l}\text { name of settlement } \\
\text { TOTAL SETTLED } \\
\text { AREA OF } \\
\text { SETTLEMENT }\end{array}$} & \multicolumn{3}{|c|}{$\begin{array}{l}\text { construction of } \\
\text { individual houses }\end{array}$} & \multicolumn{3}{|c|}{$\begin{array}{l}\text { construction of } \\
\text { apartment buildings }\end{array}$} & \multicolumn{3}{|c|}{$\begin{array}{l}\text { mixed - residential } \\
\text { and economic activities }\end{array}$} & \multicolumn{3}{|c|}{ economic activities } & \multicolumn{3}{|c|}{ total } \\
\hline & & $\begin{array}{c}1992 / \\
1998 \\
\%\end{array}$ & $\begin{array}{c}1999 / \\
2005 \\
\%\end{array}$ & $\begin{array}{c}1992 / \\
2005 \\
\%\end{array}$ & $\begin{array}{c}1992 / \\
1998 \\
\%\end{array}$ & $\begin{array}{c}1999 / \\
2005 \\
\%\end{array}$ & $\begin{array}{c}1992 / \\
2005 \\
\%\end{array}$ & $\begin{array}{c}1992 / \\
1998 \\
\%\end{array}$ & $\begin{array}{c}1999 / \\
2005 \\
\%\end{array}$ & $\begin{array}{c}1992 / \\
2005 \\
\%\end{array}$ & $\begin{array}{c}1992 / \\
1998 \\
\%\end{array}$ & $\begin{array}{c}1999 / \\
2005 \\
\%\end{array}$ & $\begin{array}{c}1992 / \\
2005 \\
\%\end{array}$ & $\begin{array}{c}1992 / \\
1998 \\
\%\end{array}$ & $\begin{array}{c}1999 / \\
2005 \\
\%\end{array}$ & $\begin{array}{c}1992 / \\
2005 \\
\%\end{array}$ \\
\hline \multirow{2}{*}{\multicolumn{2}{|c|}{$\begin{array}{l}\text { spodnja Besnica and } \\
\text { Zgornja Besnica }\end{array}$}} & & & & & & & & & & & & & & & \\
\hline & & 0.52 & 0.3 & 0.39 & - & - & - & 1.61 & 0 & 0.62 & 1.05 & 0.18 & 0.52 & 0.63 & 0.27 & 0.41 \\
\hline 2 & Ihan & 0.81 & 0.3 & 0.53 & 17.75 & 0 & 7.83 & 1.82 & 0 & 0.83 & 0.06 & 0.36 & 0.22 & 0.54 & 0.31 & 0.42 \\
\hline 3 & Brdinje & 1.27 & 0.14 & 1.01 & - & - & - & 0.4 & 0 & 0.3 & 10.04 & 0 & 7.61 & 1.22 & 0.12 & 0.97 \\
\hline 4 & Lipovci & 0.25 & 0.46 & 0.33 & - & - & - & 0 & 0 & 0 & 0.39 & 1.72 & 0.92 & 0.27 & 0.72 & 0.45 \\
\hline 5 & Krčevina pri Vurbergu & 2.17 & 0.16 & 0.93 & - & - & - & 2.24 & 0.81 & 1.35 & 0.68 & 0.25 & 0.42 & 2.08 & 0.19 & 0.91 \\
\hline 6 & Uršna Sela & 0.9 & 0.29 & 0.66 & 0 & 0 & 0 & 0.58 & 2.72 & 1.4 & 0.34 & 0 & 0.21 & 0.82 & 0.36 & 0.64 \\
\hline 7 & Žužemberk & 0.54 & 0.33 & 0.41 & 0 & 0 & 0 & 1.16 & 0 & 0.45 & 0.67 & 1.21 & 1 & 0.6 & 0.43 & 0.5 \\
\hline 8 & Velike Lašče & 1.97 & 0.14 & 0.98 & 0 & 0 & 0 & 0.92 & 0 & 0.42 & 1.39 & 1.39 & 1.39 & 1.64 & 0.52 & 1.04 \\
\hline 9 & Lož and Stari trg pri L. & 0.48 & 0.09 & 0.24 & 0.52 & 0 & 0.2 & 0.42 & 0 & 0.16 & 0.33 & 0 & 0.13 & 0.4 & 0.04 & 0.18 \\
\hline 10 & Parecag & 0.9 & 0.26 & 0.5 & 0 & 0 & 0 & 1.65 & 0.22 & 0.77 & 1.1 & 0 & 0.42 & 1.05 & 0.19 & 0.52 \\
\hline 11 & Križ and Šepulje & 2.91 & 0.18 & 1.34 & - & - & - & 1.68 & 0 & 0.72 & 5.52 & 0 & 2.33 & 3.08 & 0.15 & 1.4 \\
\hline$\Sigma$ & total & 1.06 & 0.26 & 0.63 & 1.6 & 0 & 0.74 & 1.06 & 0.18 & 0.59 & 0.62 & 0.48 & 0.55 & 0.96 & 0.3 & 0.61 \\
\hline
\end{tabular}




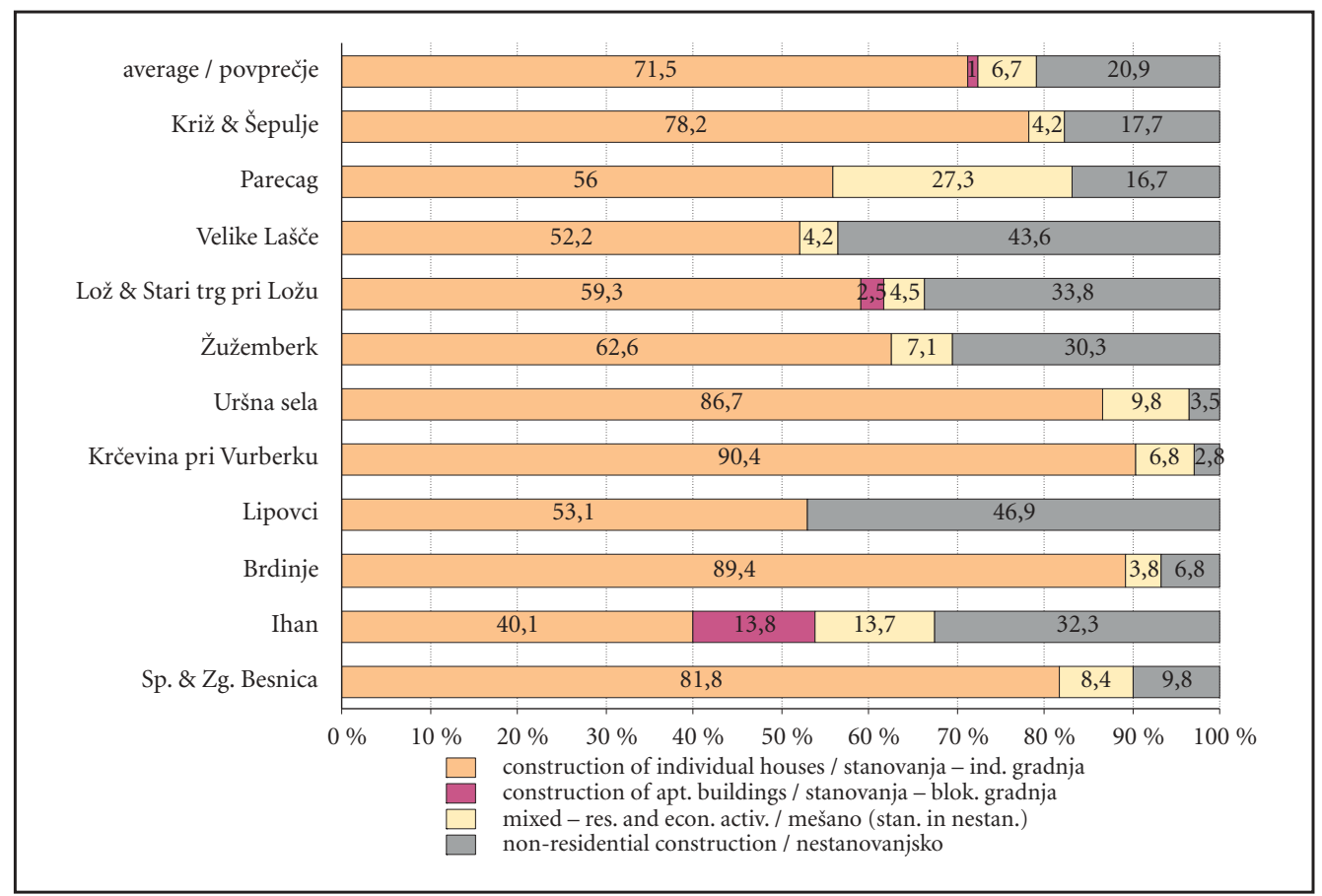

Figure 23: Structure in the period 1992-2005 of areas of new construction in the total settled area by settlement.

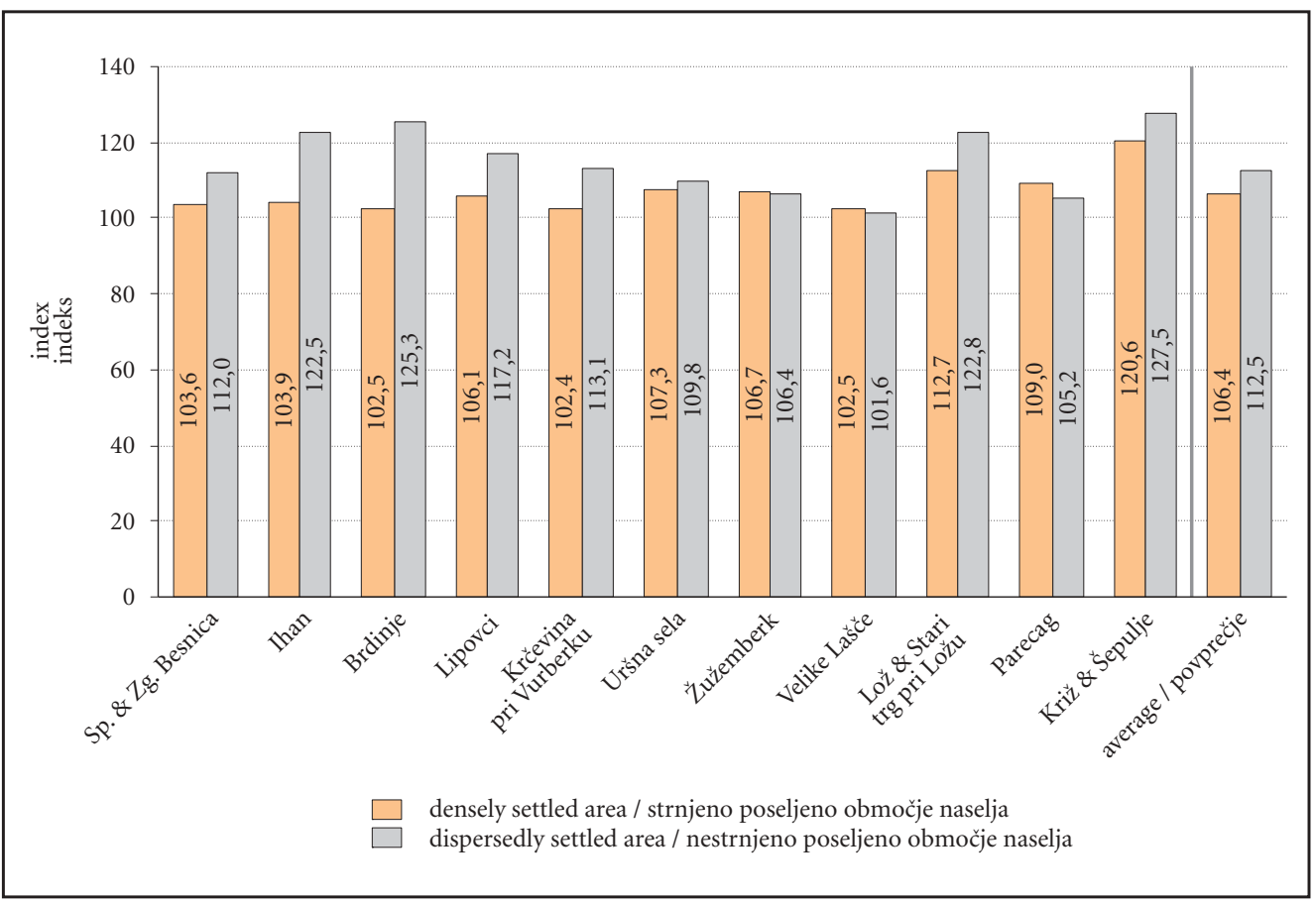

Figure 24: Index of growth in built-up areas for the period 2005/1992 (1992 = 100) by type of settlement and by settlement. 
(Figure 24). This trend is typical for the majority of the settlements analyzed. In the case of Lož-Stari trg and Žužemberk, the role of the edge is played by smaller neighboring settlements (elements of suburbanization at the local level). Although Parecag is a dispersed settlement, it is, like many rural settlements in Slovenian Istria, made up of several smaller hamlets. These take the role of concentration within settlements, where most of the new construction takes place. The strengthening of construction at the edge of the settlement, in the zone of dispersed settlement, is typical for all types of construction (Figure 25), but especially for residential and mixed-function construction.

The growth of construction was not evenly paced throughout the whole of the period analyzed. New construction was concentrated in the early and mid-1990s, while in the second half of the period it fell noticeably (Table 12). In total the intensiveness of new construction in the second half dropped by a factor of 3 (the average rate of growth in built-up areas was $1 \%$ in the first period and only $0.3 \%$ in the second); for housing construction it dropped by a factor of 4 and for mixed-function construction by a factor of 6 . A lower drop was recorded only for non-residential construction, which compared to the first half of the period decreased by only $23 \%$. This trend is typical for all settlements (Figure 26) with the exception of Lipovci, where the intensiveness of construction increased as a whole, primarily due to the increase in non-residential areas in the dispersedly settled part of the settlement (in the industrial complex by the railway).

\section{Conclusion}

This article examines the characteristics of the settled area in Slovene rural settlements and the spatial and functional changes in these settlements over a 15 -year period beginning with the independence of Slovenia in 1991. The analysis is based on aerial photos from 1991, orthophotos from 2002 and field surveys in 2005. Quantitative changes were found in 11 settlement units (14 actual settlements) occupying a total area of 9664.57 ha and making up an expert, not a statistical, sample. The settlements in the sample were selected from a subset of Slovene rural settlements which showed growth in the numbers of inhabitants and houses in the period from 1991 to 2002 , had a population between 500-1100 in 2002, a relatively high

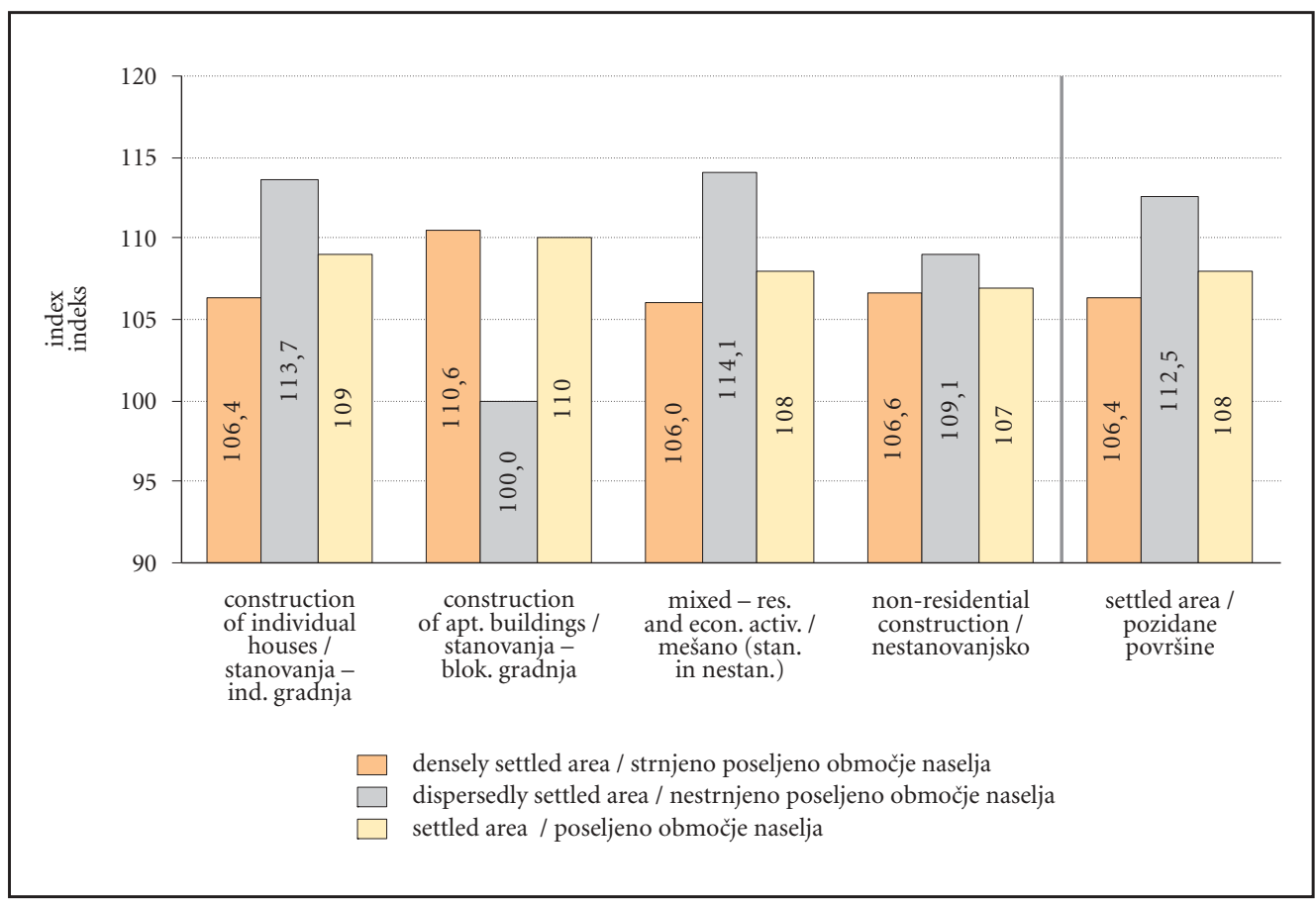

Figure 25: Average index of growth of built-up areas of individual kinds by type of settlement (period 2005/1992, 1992=100). 


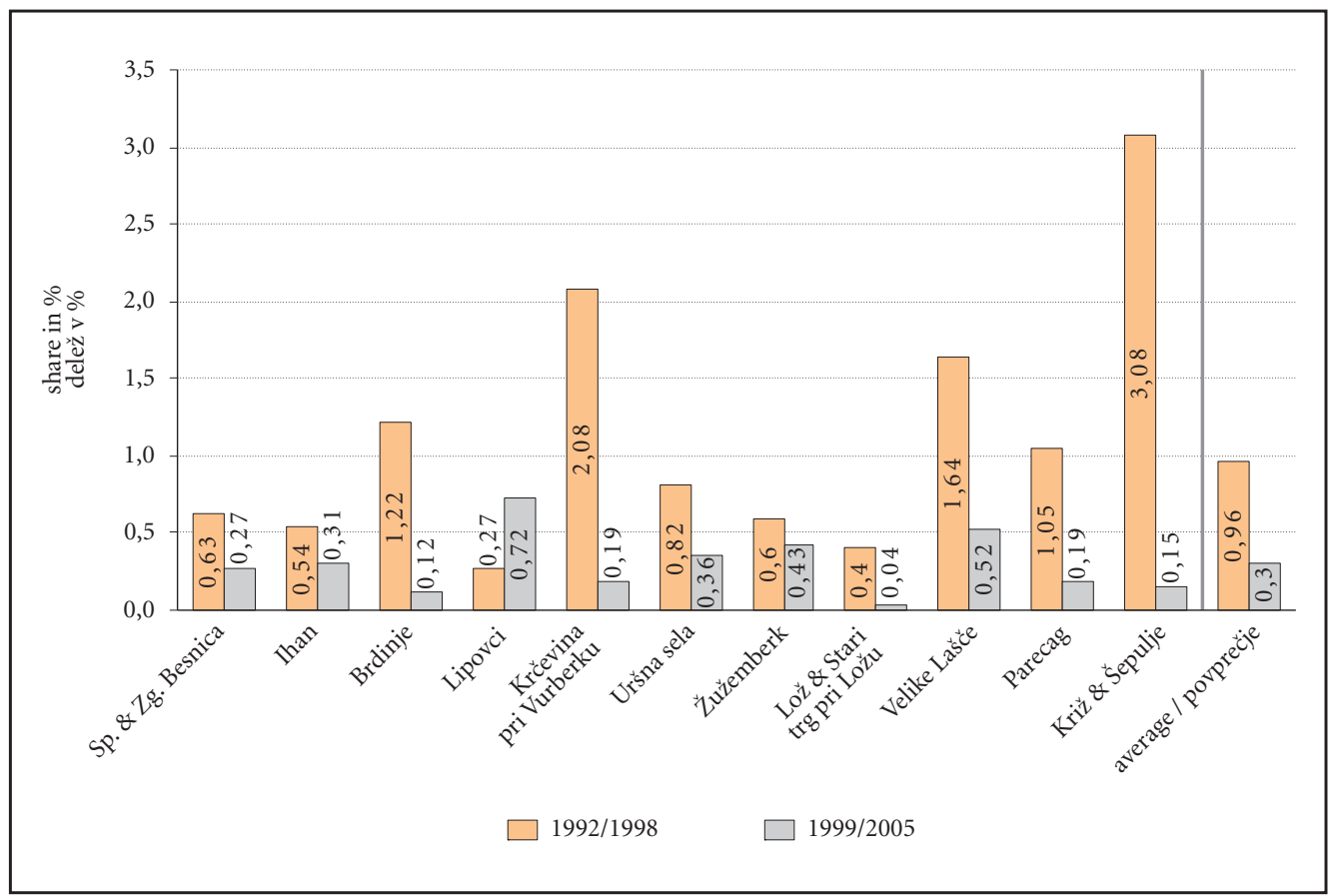

Figure 26: Average annual rate of growth for the periods 1992/1998 and 1999/2005 by settlement $(1992=100)$.

share of the population engaged in farming, and may have some central functions present. A variety of morphological settlement types and Slovene natural and statistical regions were represented.

At the level of the individual settlement, we were interested in only the settled area where buildings are actually located; larger tracts of agricultural land, forest, and the traffic areas within them were excluded. On average $23.5 \%$ of the area of the settlements studied consist of settled areas. In addition to the area covered by buildings of various types is a 100-meter belt of surrounding land.

We distinguished between densely settled and dispersedly settled areas - the former make up a fourth, and the latter three-fourths of the total settled area. The structure of both areas varies greatly, depending on relief, hydrological conditions, and morphological type of settlement. In densely settled areas, built-up areas made up about $36 \%$ of the total, traffic areas $9 \%$, patches of greenery and agricultural land $47 \%$, and small stands of forest about $8 \%$, while in dispersedly settled areas the built-up area was on average $5 \%$ of the total, traffic areas were $4 \%$, green areas and agricultural land $64 \%$, and forested land $26 \%$. The distribution of state highways, as well as natural features and land-holding structure, has an influence on the share of traffic areas in the total (that's why Lipovci, for example, has a share of road surfaces well above the average). Sports grounds and parks and water areas are not present in all settlements and take up at most a small percentage of the area; they are not related to the degree of concentration of the settlement but to the number and structure of jobs and distance from urban centers.

Within the settled areas the greatest attention was given to built-up areas, which on average took up $13 \%$ of the settled area (36\% in densely settled and $5 \%$ in dispersedly settled parts). The built-up areas in the densely settled areas were taken up mainly by housing $(68 \%)$, while $25 \%$ of the buildings there were devoted to economic activities and $7 \%$ had a mixture of functions. In the dispersedly settled areas the proportions were not significantly different: $71 \%$ of built-up areas consisted of housing, $23 \%$ of buildings devoted to economic activities, and $6 \%$ had a mixture of functions. Only a little more than $1 \%$ of the housing area was occupied by multi-unit apartment buildings, and these were present in only half the settlements; the number of such buildings was lower than 10 .

One of the more important socio-economic characteristics of the settlement sample was the commuting by the majority of the working population ( $74 \%$ on average) to nearby centers of employment. Only 
two of eleven settlement units had a surplus of jobs over the economically active population. These were Lož/Stari trg and Žužemberk, centers of employment, whereas the remaining settlements were sources of, not destinations for, workers.

Of the settlements in our sample, based on Vrišer's classification four have no central functions, four have the first, or lowest, level of central function, and three have some specialized services and a level two classification of centrality.

Within our sample three categories of settlements may be clearly distinguished:

- local and employment centers which are far from urban centers, where central functions are being strengthened, and suburbanization and expansion of residential areas are less intensive. Businesses here offer a number of jobs.

- settlements which offer, in addition to farm-related employment, a small number of jobs in manufacturing in plants which grew up during the polycentric development process of the past, and which have close connections with nearby urban centers,

- settlements in regions undergoing intense suburbanization, where jobs are scarce and are usually associated with farming or independent businesses with fewer than four employees, and where the vast majority of economically active residents commute to variably distant employment centers. The area covered by residential buildings and their accompanying infrastructure is expanding.

The function of buildings was determined based on the registry of the Agency of the Republic of Slovenia for Public Legal Records and Related Services (Slovene acronym AJPES) for 2002. We verified, corrected, and updated the information in the field in 2005. Because the standard classifications of activities used by the Statistical Office of the Republic of Slovenia in 1991 and 2002 are not the same, we had to group activities together in a way that made sense for the sake of comparability. In this way we obtained 7 categories: agricultural activities, manufacturing, construction, trade, hotels and restaurants, transport, and other service activities. The eighth category combines two or more different activities.

Regarding the characteristics of new building construction from 1992 to 2005 in the settlements studied, we can conclude the following:

- the majority of new construction (about 70\%) was for residential purposes, about $20 \%$ for non-residential purposes, and about $10 \%$ for a mixture of residential and non-residential purposes;

- new construction was most intensive in regions of more recent suburbanization, less intense in settlements which had already been affected by suburbanization processes before 1990 and in larger central settlements;

- the growth in the number of new buildings was in general greater in dispersed settlements than in nucleated or roadside settlements;

- in dispersedly settled parts of settlements residential and multi-purpose construction strongly predominated, while in densely settled parts of settlements there was a somewhat higher share of non-residential construction (about one-fourth the total);

- for all types of construction the growth in built-up areas was higher in dispersedly settled than in densely settled parts of settlements;

- new construction activity dropped off noticeably in the second half of the period under study, especially for residential and multi-purpose construction, somewhat less so for non-residential;

- the growth in non-residential built-up areas was frequently associated with new buildings put up by one or two businesses;

- the extent of new construction was not disproportionately connected with the size of the settlement, but rather with in-migration into the settlement.

\section{References}

Cigale, D. 2002: Centralna naselja v Sloveniji in njihova vplivna območja v letu 1999. Geografski vestnik 74-1, 43-56. Ljubljana.

Digitalna karta osi kategoriziranih državnih cest 2005. Direkcija Republike Slovenije za ceste. Ljubljana.

Državna topografska karta v merilu 1:25.000, listi: 017 Murska Sobota, 025 Ravne, 026 Slovenj Gradec, 035 Ljutomer, 057 Zlatoličje, 071 Tržič, 094 Kranj, 096 Kamnik, 116 Ljubljana, 117 Dolsko, 147 Branik, 148 Vipava, 154 Velike Lašče, 156 Žužemberk, 163 Sežana, 168 Lož, 169 Divača, 173 Črmošnjice, 174 Semič, 193 Dragonja/Dragogna. Geodetska uprava Republike Slovenije, 1995-1999. Ljubljana. 
EHIŠ in število prebivalcev po hišnih številkah za popisa 1991 in 2002 (MNZ-CRP) za celotno Slovenijo. Statistični urad Republike Slovenije. Ljubljana.

Kladnik, D., Ravbar, M. 2003: Členitev slovenskega podeželja, Prispevek k usmerjanju skladnega regionalnega razvoja. Geografija Slovenije 8. Ljubljana.

Krajevni leksikon Slovenije. Ljubljana, 1995.

Krevs, M. 2004: Dinamika spreminjanja kategorij poselitvene rabe zemljišč v Sloveniji v obdobju 1991-2002. Zaključno poročilo, Oddelek za geografijo Filozofske fakultete Univerze v Ljubljani. Ljubljana.

Krevs, M. 2005: Regionalna primerjava spreminjanja poselitvene rabe zemljišč med statističnimi regijami v Sloveniji v obdobju 1991-2002: po vzorčnih mestnih in suburbanih območjih. Zaključno poročilo, Oddelek za geografijo Filozofske fakultete Univerze v Ljubljani. Ljubljana.

Letalski posnetki 1990-1992. Geodetska uprava Republike Slovenije. Ljubljana.

Območja naselij 2004. Geodetska uprava Republike Slovenije. Ljubljana.

Ortofotografski posnetki 1997 in 1998. Geodetska uprava Republike Slovenije. Ljubljana.

Popis prebivalstva, gospodinjstev, stanovanj in kmečkih gospodarstev 1991. Statistični urad Republike Slovenije. Ljubljana.

Popis prebivalstva, gospodinjstev in stanovanj 2002. Statistični urad Republike Slovenije. Ljubljana.

Poslovni register AJPES 2002. Agencija Republike Slovenije za javnopravne evidence in storitve. Ljubljana.

Ravbar, M. 1998: Značilnosti urbanizacije. Geografski atlas Slovenije, 310-313. Ljubljana.

Ravbar, M., Drozg, D., Mušič, V., Lobnik, U., Koželj, J. 2001: Poselitev in prostorski razvoj Slovenije. Elaborat, Inštitut za geografijo. Ljubljana.

Ravbar, M. 2002: Sodobne težnje v razvoju prebivalstva in delovnih mest - pot k sonaravnemu in decentraliziranemu usmerjanju poselitve v Sloveniji? IB revija 36-1, 12-34. Ljubljana.

Statistični letopis Republike Slovenije 2005, Pregled po mestnih občinah, 582-586. Ljubljana.

Topole, M., Bole, D., Petek, F., Repolusk, P. 2005: Regionalna primerjava spreminjanja poselitvene rabe zemljišč med statističnimi regijami v Sloveniji v obdobju 1991-2002: po vzorčnih podeželskih območjih. Zaključno poročilo, Geografski inštitut Antona Melika ZRC SAZU. Ljubljana.

Terensko delo januar-avgust 2005. Geografski inštitut Antona Melika ZRC SAZU. Ljubljana.

Urbanc, M. 2002: Kulturne pokrajine v Sloveniji. Geografija Slovenije 5. Ljubljana.

Vrišer, I. 1998: Središčna (centralna) naselja. Geografski atlas Slovenije, 308-309. Ljubljana. 


\section{Prostorske in funkcijske spremembe pozidanih zemljišč $\mathbf{v}$ izbranih slovenskih podeželskih naseljih po letu 1991}

UDC: $911.373(497.4)$

COBISS: 1.01

IZVLEČEK: S pomočjo analiz letalskih posnetkov in ortofotografskih posnetkov, statističnih podatkov in podatkov, pridobljenih na terenu smo ugotavljali spreminjanje poselitvene rabe podeželskih naselij. Raziskava je zajela 14 podeželskih naselij s 500 do 1100 prebivalci iz različnih slovenskih naravnih in statističnih regij, ki so v zadnjem desetletju kazala pozitivno rast glede števila prebivalcev, delovnih mest in stavb. Ugotavljali smo, kako so se v obdobju med letoma 1991 in $2005 \mathrm{v}$ poseljenem območju spreminjale naslednje kategorije: stanovanjske površine, površine z oskrbnimi, storitvenimi in poslovnimi ali tako imenovanimi središčnimi funkcijami, prometne površine, ter zelene in druge odprte površine. Pokazale so se predvsem razlike med posameznimi tipi naselij. Rabo zemlijišč smo povezali z reliefom oziroma tipom poselitve, z geografskim položajem naselij, s spreminjanjem njihove strukture, z gibanjem števila delovnih mest in dnevno mobilnostjo.

KLJUČNE BESEDE: geografija podeželja, slovensko podeželje, poselitev, morfologija naselij, raba tal, delovna mesta, dnevna mobilnost, suburbanizacija, pozidane površine, novogradnje.

Uredništvo je prejelo prispevek 29. maja 2006.

NASLOVI:

Maja Topole, dr.

Geografski inštitut Antona Melika

Znanstvenoraziskovalni center Slovenske akademije znanosti in umetnosti

Gosposka ulica 13, SI - 1000 Ljubljana,

Slovenija

E-pošta: maja.topole@zrc-sazu.si

David Bole, univ. dipl. geogr.

Geografski inštitut Antona Melika

Znanstvenoraziskovalni center Slovenske

akademije znanosti in umetnosti

Gosposka ulica 13, SI - 1000 Ljubljana,

Slovenija

E-pošta: david.bole@zrc-sazu.si

\section{Kazalo}

$1 \quad$ Uvod

2 Metodologija

2.1 Opredelitev podeželskega naselja in izbor vzorca naselij

2.2 Zajem podatkov

2.3 Terminologija

3 Družbenogospodarske značilnosti vzorca naselij

Raba tal in gostota delovnih mest

Spremembe rabe tal v obdobju od 1992 do 2005

Sklep

Viri in literatura
Franci Petek, dr.

Geografski inštitut Antona Melika

Znanstvenoraziskovalni center Slovenske akademije znanosti in umetnosti Gosposka ulica 13, SI - 1000 Ljubljana, Slovenija

E-pošta: franci.petek@zrc-sazu.si

Peter Repolusk, univ. dipl. geogr. in zgod. Geografski inštitut Antona Melika Znanstvenoraziskovalni center Slovenske akademije znanosti in umetnosti Gosposka ulica 13, SI - 1000 Ljubljana, Slovenija

E-pošta: peter.repolusk@zrc-sazu.si 


\section{Uvod}

Nova gospodarska in družbena politika po slovenski osamosvojitvi leta 1991 je vplivala tudi na slovenske poselitvene razmere. Procesi, ki so se sicer začeli že prej, so bili v tem obdobju intenzivnejši, poleg tega so se poglabljale razlike znotraj države.

S preučitvijo vzorca 284 podeželskih naselij, ki so v tem času rasla po številu prebivalcev, hiš in delovnih mest, smo poskušali odgovoriti na vprašanje, kakšne in kolikšne so bile te spremembe pri podeželskih naseljih v 15 letih od osamosvojitve dalje. Poselitveno stanje čim bližje letu 1991 smo ugotavljali s pomočjo letalskih posnetkov, stanje čim bližje popisnemu letu 2002 smo povzeli po ortofotografskih posnetkih, stanje leta 2005 pa smo ugotovili s terenskim delom. Za vsako naselje smo izračunali povprečne letne stopnje rasti obsega pozidanih površin. Podatke smo povezali z geografskim položajem naselja, s številom prebivalcev, zaposlenih in delovnih mest ter z migracijami prebivalcev. Izvedli smo tudi kartiranje poseljenih območij naselij, da bi ugotovili kvantitativne podatke ter zakonitosti in razlike v spreminjanju podeželskih naselij s prostorskega in funkcijskega vidika. Ločili smo stanovanjske površine, površine z oskrbnimi, storitvenimi in poslovnimi ali takoimenovanimi središčnimi dejavnostmi, prometne površine ter zelene in druge nepozidane površine (Topole in ostali 2005). Prispevek obravnava slovenska podeželska naselja, procese v mestnih in obmestnih naseljih pa so istočasno preučevali drugi (Krevs 2005).

\section{Metodologija}

\subsection{Opredelitev podeželskega naselja in izbor vzorca naselij}

Ker so razpoložljiva sredstva za raziskavo onemogočila izbor dovolj velikega statističnega vzorca naselij, ki bi bil terensko obvladljiv, smo bili prisiljeni izbrati reprezentativen ekspertni vzorec naselij, ki bi nakazoval različne možne smeri razvoja poselitvenih površin glede na različne naravne razmere in tipe naselij.

V Sloveniji ni formalne razlage izraza podeželsko naselje. Statistični urad Republike Slovenije deli naselja na mestna in nemestna, tako da lahko vsa nemestna naselja štejemo za podeželska.

Statistični letopis Republike Slovenije 2005 šteje med mestna naselja in naselja mestnih območij 156 slovenskih naselij. V njih živi 967.496 ali 49,5\% prebivalstva Slovenije in 48,5\% delovno aktivnega prebivalstva. Za uvrstitev med mestna naselja morajo kraji izpolnjevati vsaj enega od naslednjih meril:

- imajo 3000 ali več prebivalcev (formalno merilo) ali

- imajo 2000 do 2999 prebivalcev in več delovnih mest, kot je delovno aktivnega prebivalstva, stanujočega v teh naseljih (formalno, funkcijsko merilo) ali

- so sedeži občin in imajo vsaj 1400 prebivalcev ter presežek delovnih mest oziroma so naselja sedeži občin in imajo vsaj 2000 prebivalcev (formalno, funkcijsko merilo) ali

- spadajo v mestno območje in imajo manjše število prebivalcev, a se z določenim mestnim naseljem, ki ima več kot 5000 prebivalcev in sklenjeno pozidavo, zraščajo v enovito funkcionalno celoto. Kot merilo funkcionalne povezanosti smo upoštevali zaposlitveno migracijo, kot izločitveno merilo pa delež kmetijskih gospodinjstev v obmestnem naselju (fiziognomsko-morfološko, funkcijsko merilo).

V Sloveniji je bilo 1.1.2005 kar 5842 ali $97 \%$ nemestnih naselij, v njih je živela dobra polovica prebivalcev Slovenije ( 985.809 ali 50,5\%). Na ta naselja odpade 51,5\% delovno aktivnega prebivalstva. Med njimi smo vzorec izbrali tako, da smo upoštevali dodatne pogoje:

- naselje je relativno veliko in je v njem leta 2002 živelo 500-1100 ali povprečno 900 ljudi,

- v obdobju 1991-2002 je število prebivalcev in število hiš v naselju raslo,

- po podatkih za leto 1991 je imelo naselje relativno velik delež kmečkih prebivalcev in sicer od 3,7 \% (Lož s Starim trgom) do $21 \%$ (Lipovci) in velik delež strnjenih kmetijskih in gozdnih površin,

- občinska središča so vključena le izjemoma, če imajo manj kot 1400 prebivalcev (Zužemberk in Velike Lašče, Stari trg pri Ložu), tako da smo upoštevali tudi podeželska središča, ki niso v bližini velikih aglomeracij,

- naselja ležijo v različnih slovenskih naravnih regijah (Urbanc 2002) in zato pripadajo različnim morfološkim tipom (so strnjena in razložena oziroma gručasta, obcestna ter v obliki zaselkov in samotnih kmetij),

- naselja ležijo v različnih slovenskih statističnih regijah. 
Preglednica 1: Temeljni podatki o izbranih naseljih.

\begin{tabular}{|c|c|c|c|c|c|c|c|c|c|c|c|c|c|}
\hline & ime naselja & $\begin{array}{l}\text { površina } \\
\text { naselja v ha }\end{array}$ & $\begin{array}{l}\text { kmečko } \\
\text { prebivalstvo } \\
\text { l. } 1991 \text { v \% }\end{array}$ & & $\begin{array}{l}\text { število } \\
\text { prebivalcev }\end{array}$ & & $\begin{array}{l}\text { indeks gibanja } \\
\text { preb. 2002/1991 }\end{array}$ & $\begin{array}{l}\text { naravna } \\
\text { regija }\end{array}$ & $\begin{array}{l}\text { pokrajinski tip } \\
\text { (Urbanc 2002) }\end{array}$ & občina & $\begin{array}{ll}\text { statistična } & 0 \\
\text { regija } & 0 \\
& \end{array}$ & $\begin{array}{l}\text { oddaljenost } \\
\text { od mesta } \\
\text { v km }\end{array}$ & $\begin{array}{l}\text { morfološki } \\
\text { tip naselja }\end{array}$ \\
\hline & & & & $\begin{array}{l}1991 \text { stara } \\
\text { metodologija }\end{array}$ & $\begin{array}{l}1991 \text { nova } \\
\text { a metodologija }\end{array}$ & 2002 & & & & & & & \\
\hline 1 & $\begin{array}{l}\text { Spodnja in } \\
\text { Zgornja Besnica }\end{array}$ & 1878,7605 & 5,9 & 1323 & 1316 & 1517 & 115,3 & $\begin{array}{l}\text { rob } \\
\text { Škofjeloškega } \\
\text { hribovja }\end{array}$ & $\begin{array}{c}\text { alpsko } \\
\text { a hribovje }\end{array}$ & Kranj & Gorenjska & 4 & $\begin{array}{l}\text { gručasta jedra } \\
\text { in razloženo }\end{array}$ \\
\hline 2 & Ihan & 155,9065 & 9,5 & 640 & 634 & 701 & 110,6 & $\begin{array}{l}\text { Kamniško- } \\
\text { bistriška } \\
\text { ravan }\end{array}$ & $\begin{array}{l}\text { alpska } \\
\text { ravnina }\end{array}$ & Domžale & $\begin{array}{l}\text { Osrednje- } \\
\text { slovenska }\end{array}$ & 2 & $\begin{array}{l}\text { gručasto jedro } \\
\text { in razloženo }\end{array}$ \\
\hline 3 & Brdinje & 899,6086 & 7,1 & 539 & 538 & 628 & 116,7 & $\begin{array}{l}\text { Zahodno } \\
\text { Pohorsko } \\
\text { Podravje }\end{array}$ & $\begin{array}{l}\text { alpsko } \\
\text { hribovje }\end{array}$ & $\begin{array}{l}\text { Ravne } \\
\text { na Kor. }\end{array}$ & Koroška & 2 & $\begin{array}{l}\text { obcestno, zaselki in } \\
\text { samotne kmetije }\end{array}$ \\
\hline 4 & Lipovci & 705,6035 & 21,0 & 1027 & 995 & 1047 & 105,2 & $\begin{array}{l}\text { Pomurska } \\
\text { ravan }\end{array}$ & $\begin{array}{l}\text { panonska } \\
\text { ravnina }\end{array}$ & Beltinci & Pomurska & 1,5 & gručasto \\
\hline 5 & $\begin{array}{l}\text { Krčevina pri } \\
\text { Vurbergu }\end{array}$ & 969,7857 & 19,1 & 646 & 607 & 811 & 133,6 & $\begin{array}{l}\text { Slovenske } \\
\text { gorice }\end{array}$ & $\begin{array}{c}\text { panonsko } \\
\text { gričevje }\end{array}$ & Ptuj & Podravska & 6 & $\begin{array}{l}\text { razloženo, delno } \\
\text { obcestno }\end{array}$ \\
\hline 6 & Uršna Sela & 1200,3761 & 10,4 & 546 & 541 & 588 & 108,7 & $\begin{array}{l}\text { Novomeška } \\
\text { pokrajina }\end{array}$ & $\begin{array}{l}\text { dinarsko } \\
\text { podolje }\end{array}$ & $\begin{array}{l}\text { Novo } \\
\text { mesto }\end{array}$ & JV Slovenija & 12 & $\begin{array}{l}\text { razloženo, delno } \\
\text { gručasto in } \\
\text { obcestno }\end{array}$ \\
\hline 7 & Žužemberk & 776,5692 & 6,8 & 991 & 979 & 1085 & 110,8 & Suha krajina & dinarski ravnik & Žužemberk & JV Slovenija & 17,5 & $\begin{array}{l}\text { gručasta jedra } \\
\text { in razloženo }\end{array}$ \\
\hline 8 & Velike Lašče & 597,3676 & 6,9 & 561 & 551 & 639 & 116,0 & $\begin{array}{l}\text { Velikolaščanska } \\
\text { pokrajina }\end{array}$ & $\begin{array}{r}\text { ka dinarsko } \\
\text { podolje }\end{array}$ & $\begin{array}{l}\text { Velike } \\
\text { Lašče }\end{array}$ & $\begin{array}{l}\text { Osrednje- } \\
\text { slovenska }\end{array}$ & 14 & $\begin{array}{l}\text { gručasto jedro, } \\
\text { razloženo }\end{array}$ \\
\hline 9 & $\begin{array}{l}\text { Lož in Stari trg } \\
\text { pri Ložu }\end{array}$ & 899,6086 & 3,7 & 1315 & 1307 & 1377 & 105,4 & $\begin{array}{l}\text { Notranjsko } \\
\text { podolje }\end{array}$ & $\begin{array}{l}\text { dinarsko } \\
\text { podolje }\end{array}$ & $\begin{array}{l}\text { Loška } \\
\text { dolina }\end{array}$ & $\begin{array}{l}\text { Notranjsko- } \\
\text { kraška }\end{array}$ & 14 & $\begin{array}{l}\text { gručasti jedri } \\
\text { in razloženo }\end{array}$ \\
\hline 10 & Parecag & 982,2554 & 6,9 & 760 & 751 & 910 & 121,2 & $\begin{array}{l}\text { Koprsko } \\
\text { primorje }\end{array}$ & $\begin{array}{l}\text { sredozemsko } \\
\text { gričevje }\end{array}$ & Piran & $\begin{array}{c}\text { Obalno- } \\
\text { kraška }\end{array}$ & 4,5 & $\begin{array}{l}\text { gručasto jedro, } \\
\text { razloženo }\end{array}$ \\
\hline 11 & Križ in Šepulje & 598,7303 & 11,2 & 432 & 438 & 580 & 132,4 & Kras & $\begin{array}{l}\text { sredozemska } \\
\text { kraška planota }\end{array}$ & Sežana & $\begin{array}{l}\text { Obalno- } \\
\text { kraška }\end{array}$ & 5 & gručasto \\
\hline$\Sigma$ & skupaj & 9664,5720 & 9,4 & 8780 & 8657 & 9883 & 114,0 & I & 1 & 1 & 1 & 7,5 & I \\
\hline
\end{tabular}


Temeljna značilnost spreminjanja naselij v Sloveniji je rast mestnih in upad nemestnih naselij. Med letoma 1991 in 2002 se je število registriranih hišnih enot (EHIŠ) najbolj povečalo v Ljubljani (+3032), sledila so ostala večja mestna naselja (Maribor, Novo mesto, Kranj, Koper, Celje). V 1291 naseljih se število EHIŠ ni povečalo, 958-im se je povečalo za več kot 10 enot.

V istem obdobju se je po popisnih podatkih število prebivalcev povečalo 3338 naseljem, v 236 naseljih je ostalo enako, število prebivalcev pa se je zmanjšalo 2318 naseljem. Najbolj so se povečala naselja, ki so v neposredni bližini večjih mest.: Logatec, Ig, Trzin, Vrhnika, Grosuplje (bližina Ljubljane), Sv. Anton (bližina Kopra). Prav tako so se povečala nekatera naselja v bližini manjših urbanih središč, na primer Kotlje pri Slovenj Gradcu ali Lucija pri Piranu. Najbolj je število prebivalcev upadlo v mestnih naseljih Maribor, Jesenice, Ljubljana, Celje ter podeželskih naseljih, ki so oddaljena od mestnih središč.

Naš vzorec vsebuje 11 poselitvenih enot oziroma 14 naselij. Poleg osmih samostojnih naselij (Ihan, Brdinje, Lipovci, Krčevina pri Vurbergu, Uršna sela, Žužemberk, Velike Lašče in Parecag) smo obravnavali še tri pare naselij, ki tvorijo morfološko in demografsko homogene enote: Spodnjo in Zgornjo Besnico, Lož in Stari trg pri Ložu ter Križ in Šepulje.

Kraji imajo različno nadmorsko višino - od $0 \mathrm{~m}$ oziroma povprečja $20 \mathrm{~m}$ v primeru Parecaga do $685 \mathrm{~m}$ oziroma povprečja $450 \mathrm{~m}$ v primeru Brdinja. Razprostranjeni so v območjih vseh treh poglavitnih slovenskih podnebnih tipov: $\mathrm{v}$ zmernocelinskem, submediteranskem in gorskem. Od najbližjih mestnih naselij so oddaljena $1,5 \mathrm{~km}$ do $17,5 \mathrm{~km}$, povprečno $7,5 \mathrm{~km}$, od najbližje prometnice ranga avtoceste ali hitre ceste pa od $1 \mathrm{~km}$ do $29,8 \mathrm{~km}$ ali povprečno 10,2 km. Naselja, zajeta v ekspertnem vzorcu, tudi z Zakonom o lokalni samoupravi niso bila opredeljena kot mestna naselja. Temeljne podatke o njihovem prebivalstvu in prostorski pripadnosti prikazujeta slika 1 in preglednica 1.

Slika 1: V ekspertnem vzorcu zastopana slovenska podeželska naselja.

Glej angleški del prispevka.

Slika 2: Število prebivalcev leta 2002 in indeks rasti prebivalstva 2002/1991.

Glej angleški del prispevka.

\subsection{Zajem podatkov}

Poselitveno rabo znotraj naselja smo ugotavljali na dveh vsebinskih ravneh. Na prvi smo v naselju ločili stavbe s pripadajočim funkcionalnim zemljiščem, prometnice, zelene površine (parki, vrtovi, obcestni zeleni pas in podobno), gozd, vode ter druge oblike nepozidanih zemljišč. Stavbam smo potem posebej določili funkcijo in sicer stanovanjsko ali nestanovanjsko, če smo ugotovili vsaj še eno nestanovanjsko funkcijo, pa še mešano oziroma stanovanjsko-nestanovanjsko.

Spremembe v obsegu poselitvenega območja (širjenje in zgoščevanje) smo ugotavljali iz letalskih posnetkov (1990-1992), iz prve generacije ortofotgrafskih posnetkov (1997-2000) ter s terenskim delom (2005). Podatk smo vnašali z digitalizacijo oziroma vektorizacijo kategorij poselitvene rabe na podlagi ortofotografskih posnetkov s pomočjo orodja ARC GIS. Temeljni vektorski sliki smo dodali popravke za stanje pred in po nastanku ortofotografskih posnetkov. Določeno površino smo opredelili kot zeleno ali odprto le, če je v dolžino in širino merila vsaj $17 \mathrm{~m}$ in je omogočala gradnjo manjših samostojnih objektov; v nasprotnem primeru smo okolico stavb (zelenica, vrt, dvorišče) ter stavbe združili v enoten poligon pozidanih površin.

Na tematskem zemljevidu smo za vsako naselje prikazali stanje pozidanega območja ob začetnem letu (pri posameznih naseljih to ni enotno; upoštevan je podatek, ki je časovno najbližje popisnemu letu 1991 - preglednica 2), ob nastanku ortofota ali letalskega posnetka, iz katerega je bil izdelan ortofotografski posnetek (okrog leta 1997 - preglednica 2) ter leta 2005, ko smo opravili terenski ogled.

Tako smo ugotovili:

- obseg pred letom 1991 pozidanega območja,

- obseg območja, pozidanega med letoma 1991 in 1997 ter

- obseg območja, pozidanega v zadnjih 8 ali manj letih.

Končni nabor kategorij pozidanih površin tal s prve vsebinske ravni je sledeči (z zvezdico ${ }^{\star}{ }^{*}$ so označene najpogostejše letnice, točne letnice za posamezna naselja glej v preglednici 2):

- stanovanjsko območje - stanje leta $1992^{*}$

- stanovanjsko območje - stanje leta $1997^{\star}$

- stanovanjsko območje - stanje leta $2005^{\star}$ 
- mešana stanovanjsko-nestanovanjska raba - stanje leta $1992^{\star}$

- mešana stanovanjsko-nestanovanjska raba - stanje leta $1997^{\star}$

- mešana stanovanjsko-nestanovanjska raba - stanje leta $2005^{\star}$

- nestanovanjska raba - stanje leta $1992^{\star}$

- nestanovanjska raba - stanje leta $1997^{\star}$

- nestanovanjska raba - stanje leta $2005^{\star}$

- prometnice (pot, cesta, parkirišče, železnica) 1997

- zelene in kmetijske površine 1997

- vode 1997

- druga nepozidana zemljišča (smetišče, kamnolom in podobno) 1997.

Preglednica 2: Leto zajema podatkov in število upoštevanih let za posamezna naselja.

\begin{tabular}{|c|c|c|c|c|c|c|c|}
\hline & ime naselja & $\begin{array}{l}\text { letalski posnetki } \\
\text { za začetno leto } \\
\text { (GURS) }\end{array}$ & $\begin{array}{l}\text { ortofoti za } \\
\text { drugo obdobje } \\
\text { (GURS) }\end{array}$ & $\begin{array}{l}\text { terensko delo } \\
\text { (GIAM ZRC } \\
\text { SAZU) }\end{array}$ & $\begin{array}{l}\text { dolžina } \\
\text { 1. intervala } \\
\text { analize v letih }\end{array}$ & $\begin{array}{l}\text { dolžina } \\
\text { 2. intervala } \\
\text { analize } \\
\text { v letih }\end{array}$ & $\begin{array}{l}\text { celotno } \\
\text { obdobje } \\
\text { (število let) }\end{array}$ \\
\hline \multirow[t]{2}{*}{1} & Spodnja in & & & & & & \\
\hline & Zgornja Besnica & 1992 & 1997 & 2005 & 5 & 8 & 13 \\
\hline 2 & Ihan & 1992 & 1998 in 1999 & 2005 & 6 & 7 & 13 \\
\hline 3 & Brdinje & 1990 & 2000 in 2003 & 2005 & 11,5 & 3,5 & 15 \\
\hline 4 & Lipovci & 1990 & 1999 & 2005 & 9 & 6 & 15 \\
\hline \multirow[t]{2}{*}{5} & Krčevina pri & & & & & & \\
\hline & Vurbergu & 1992 & 1997 & 2005 & 5 & 8 & 13 \\
\hline 6 & Uršna Sela & 1992 & 2000 & 2005 & 8 & 5 & 13 \\
\hline 7 & Žužemberk & 1992 & 1997 & 2005 & 5 & 8 & 13 \\
\hline 8 & Velike Lašče & 1992 & 1998 & 2005 & 6 & 7 & 13 \\
\hline \multirow[t]{2}{*}{9} & Lož in Stari & & & & & & \\
\hline & trg pri Ložu & 1992 & 1997 & 2005 & 5 & 8 & 13 \\
\hline 10 & Parecag & 1992 & 1997 & 2005 & 5 & 8 & 13 \\
\hline 11 & Križ in Šepulje & 1991 & 1997 & 2005 & 6 & 8 & 14 \\
\hline
\end{tabular}

Na drugi vsebinski ravni smo ugotavljali na objekte vezane dejavnosti. Vir je bil Poslovni register Agencije Republike Slovenije za javnopravne evidence in storitve (AJPES, stanje 31.12.2002). Register vsebuje centroide objektov, na katere so vezane posamezne dejavnosti. Z njegovo pomočjo smo ločili tudi nestanovanjske in mešane poselitvene rabe na prvi vsebinski ravni.

AJPES se je izkazal kot problematičen:

- če je v stavbi poslovna dejavnost, v registru AJPES pa ni navedena, ker je sedež poslovne družbe na drugi lokaciji, lahko celo v drugem naselju,

- če je dejavnost prijavljena v stavbi s čisto stanovanjsko funkcijo, izvaja pa se drugje (primer so samostojni podjetniki avtoprevozniki s sedežem podjetja na domačem naslovu, saj poleg tovornjaka ne potrebujejo dodatnih poslovnih prostorov),

- če je dejavnost označena na napačni lokaciji (napačna postavitev EHIŠ-a ali pa je napaka v naslovu).

Odstopanja, ki jih je bilo pod $10 \%$, smo v veliki meri ugotovili na terenu in jih popravili. Žal naša analiza ni zajela kmetijskih gospodarstev, saj nam ni uspelo pridobiti centroidov v Kmetijskem popisu popisanih evropsko primerljivih kmetijskih gospodarstev. AJPES vodi le evidenco kmetijskih dejavnosti kot poslovnih subjektov, kot so farme ali drevesnice.

Množico dejavnosti, ki jih vodi register AJPES, smo za analizo smiselno združili v osem kategorij:

- kmetijske dejavnosti,

- predelovalne dejavnosti,

- gradbeništvo,

- trgovina,

- gostinstvo in turizem,

- promet,

- druge storitvene dejavnosti,

- dve ali več različnih dejavnosti. 


\subsection{Terminologija}

\section{Območje naselja}

Upoštevali smo območja naselja po definiciji Geodetske uprave Republike Slovenije in v mejah, veljavnih leta 2002. Skupna površina osmih samostojnih naselij in treh parov preučevanih naselij je 9664,57 ha.

\section{Poseljene površine}

Poseljene površine smo povzeli po Krevsu $(2004,79)$. To so območja strnjene in nestrnjene poselitve skupaj, ali površine objektov skupaj s 100-metrskim radijem oziroma zelenim robom okrog njih. Poseljene površine sestavljajo: pozidane površine, prometne površine, površine, namenjene športu, razdrobljene zelene in kmetijske, gozdne in vodne površine. Vse neposeljene površine naselja oziroma strnjene gozdne, kmetijske in vodne površine, pa tudi prometne površine znotraj tega območja, so iz obravnave izvzete.

V preučevanih naseljih je 2277,32 ha poseljenih površin, ki obsegajo $23,5 \%$ površine naselij. Razlikujemo:

- strnjeno poseljene površine, ki so območja stavb skupaj s 100-metrskim radijem oziroma zelenim robom okrog njih, v katerih je delež pozidanih površin večji kot $5 \%$ (Krevs 2004, 79). V našem vzorcu naselij je strnjeno poseljenih 573,26 ha ali $25,2 \%$ površin.

- nestrnjeno poseljene površine, ki so območja stavb skupaj s 100-metrskim radijem oziroma zelenim robom okrog njih, v katerih je delež pozidanih površin $5 \%$ ali manjši. V našem vzorcu naselij je nestrnjeno poseljenih 1704,07 ha ali $74,8 \%$ površin.

Z vidika poseljenosti smo naselja združili v tri skupine: najbolj strnjeno so poseljena gručasta naselja (Lipovci, Ihan, Križ in Šepulje ter Lož in Stari trg pri Ložu). Strnjeno poseljeni del tu zavzema 46-61 \% poseljenih površin. Naselja z gručastim jedrom, sicer pa z razloženo poselitvijo (Spodnja in Zgornja Besnica, Žužemberk in Velike Lašče) imajo 30-36 \% strnjeno poseljenih površin. V razloženih naseljih (Krčevina pri Vurbergu, Brdinje, Uršna sela in Parecag) pa strnjeno poseljeni del zavzema le 1-17 \% poseljenih površin.

Slika 3: Delež poseljenih površin od vseh površin naselja (I. 2004).

Glej angleški del prispevka.

Slika 4: Delež strnjeno in nestrnjeno poseljenih površin od vseh poseljenih površin naselja (I. 2004).

Glej angleški del prispevka.

\section{Pozidane površine}

V okviru pozidanih površin imajo objekti različno namembnost:

- stanovanjski objekti so lahko:

- individualni stanovanjski objekti:

- enodružinske hiše in hiše, namenjene večgeneracijski družini,

- dvojčki,

- vrstne hiše in

- kmetije (stanovanjski objekt z gospodarskimi poslopji) ali

- večstanovanjski objekti (bloki) s štirimi ali več stanovanji;

- objekti z mešano funkcijo, ki so namenjeni bivanju in opravljanju dejavnosti (izjemoma je tam le njen sedež). Nestanovanjska funkcija je lahko gospodarska ali negospodarska (sedež društva);

- nestanovanjski objekti so namenjeni opravljanju dejavnosti (vštete so tudi notranje prometne površine, ki služijo tem dejavnostim), nestanovanjski objekti pa so lahko objekti z gospodarsko dejavnostjo (delovna mesta) ali drugačno funkcijo (gasilski dom, vaški dom);

- stavbe brez funkcije so objekti ne glede na namembnost, ki niso v rabi (najpogosteje so to opuščeni individualni stanovanjski in gospodarski objekti).

Poleg objektov smo k pozidanim površinam prišteli tudi vmesne vrtovi, dvorišča in dovoze ali tako imenovane funkcionalne površine, katerih širina in dolžina ne presega $17 \mathrm{~m}$.

V obravnavanih naseljih je 290,73 ha pozidanih površin, kar pomeni 12,8 \% vseh poseljenih površin. Od tega je 203,49 ha ali $35,5 \%$ v strnjenop poseljenih in 87,2 ha ali $5,1 \%$ v nestrnjeno poseljenih delih naselij. $70 \%$ pozidanih površin je v strnjenih in $30 \% \mathrm{v}$ nestrnjenih delih naselij. Pozidane površine in njihovi deleži bi bili precej višji, če bi jih prikazovali kot parcelne podatke. Delež pozidanih površin po posameznih naseljih je povezan z gostoto oziroma tipom poselitve ali z morfologijo naselja. 
Poglavitne značilnosti pozidanosti so naslednje. V razloženih naseljih, ki jih sestavljajo zaselki in posamično stoječe stavbe, je delež pozidanih površin manjši od $10 \%(5,8-8,1 \%)$. Taka naselja so Brdinje, Krčevina pri Vurbergu, Uršna sela in Parecag. V strnjenih naseljih obcestnega ali gručastega tipa delež pozidanih površin presega $20 \%(21,7-43,4 \%)$. Taka naselja so Ihan, Lipovci, Lož-Stari trg in Križ-Šepulje. V Velikih Laščah, Žužemberku ter Spodnji in Zgornji Besnici se prepletata oba tipa - delež pozidanih površin $\mathrm{v}$ poseljenem delu naselja znaša 10 do $20 \%$. Za ta naselja je značilna velika razlika v gostoti poselitve in pozidave med strnjenim in nestrnjenim delom naselja.

Slika 5: Delež pozidanih površin v strnjeno in nestrnjeno poseljenem delu naselja (leta 2004).

Glej angleški del prispevka.

\section{Stanovanjske površine}

Stanovanjske površine pokrivajo skupaj 202,94 ha ali 8,8 \% vseh poseljenih površin $(4,0 \%-20,7 \%)$. Od teh odpade na strnjeno poseljeni del naselij 140,9 ha ali $24,6 \%$ poseljenih površin $(8,5 \%-33,8 \%)$, na nestrnjeno poseljeni del pa 64,55 ha ali 3,6 \% poseljenih površin $(0,4 \%-5,7 \%) .69,4 \%$ stanovanjskih površin odpade torej na strnjeno poseljeni in $30,6 \%$ na nestrnjeno poseljeni del naselij.

Med pozidanimi površinami v naselju zavzemajo stanovanjske $69,0 \%$ površin $(31,8 \%-89,4 \%)$. Ta delež znižujejo naselja Ihan, Lož in Stari trg pri Ložu ter Velike Lašče z velikimi površinami za dejavnosti; brez njih bi bil delež 81,3\%. Med stanovanjskimi površinami prevladujejo individualni stanovanjski objekti, ki jih je kar 98,8\%.

Slika 6: Stanovanjske površine v naselju leta 2005.

Glej angleški del prispevka.

\section{Večstanovanjski objekti}

Večstanovanjski objekti v obravnavanih naseljih skupaj pokrivajo 2,37 ha ali 1,2\% stanovanjskih površin v poseljenem delu ( $1,6 \% \mathrm{v}$ strnjeno in $0,2 \% \mathrm{v}$ nestrnjeno poseljenem delu naselij) in $0,8 \%$ pozidanih površin. Večstanovanjski objekti so le v naseljih Parecag, Lož in Stari trg pri Ložu, Ihan, Žužemberk in Velike Lašče. Število takih objektov je povsod pod deset in še ti so navadno manjšega obsega. V upoštevanem obdobju sta bila na novo zgrajena le dva večstanovanjska objekta in sicer v središčih Ihana in Starega trga pri Ložu. Povečini pa so bile stavbe sezidane v šestdesetih in sedemdesetih letih 20. stoletja.

\section{Površine z objekti z mešano stanovanjsko-nestanovanjsko funkcijo}

Objekti z mešano funkcijo, ki služijo bivanju in dejavnostim, pokrivajo 20,03 ha ali 0,9\% poseljenih površin $(0,3 \%-1,7 \%)$ ali $6,9 \%$ pozidanih površin. Na strnjeno poseljeni del odpade 15,0 ha mešanih površin $(3,5 \%)$, na nestrnjeno poseljeni pa 5 ha $(1,2 \%)$. Tri četrtine površin $\mathrm{z}$ mešano funkcijo je $\mathrm{v}$ strnjeno poseljenem, četrtina pa v nestrnjeno poseljenem delu naselij.

Slika 7: Površine z mešano funkcijo (stanovanje in dejavnosti) v naselju leta 2005.

Glej angleški del prispevka.

\section{Površine z nestanovanjskimi objekti}

Površine z objekti, ki služijo opravljanju dejavnosti, zavzemajo 70,13 ha površin ali 3,1 \% poseljenega dela naselja $(0,1 \%-15,7 \%)$ in $24,2 \%$ pozidanih površin $(1,4 \%-60,0 \%) .50$ ha teh površin odpade na strnjeno poseljeno območje, kjer zavzemajo 8,7 \% (0\%-23,9\%), 20,14 ha pa na nestrnjeno poseljeno območje, kjer zavzemajo $1,2 \%$ površin $(0,1 \%-6,2 \%) .71,3 \%$ površin, namenjenih dejavnostim, leži v strnjeno poseljenem obmojču, $28,7 \%$ pa v nestrnjeno poseljenem območju. Naselja, ki imajo med pozidanimi površinami največji delež površin, namenjenih dejavnostim, so Ihan (60 \%), Lož in Stari trg pri Ložu (47,3 \%) ter Velike Lašče $(33,3 \%)$.

Slika 8: Površine, namenjene dejavnostim v naselju leta 2005.

Glej angleški del prispevka.

Slika 9: Delež površin, namenjenih dejavnostim v okviru vseh pozidanih površin naselja leta 2005.

Glej angleški del prispevka. 


\section{Objekti brez funkcije}

Objekti brez funkcije zavzemajo majhne površine v Brdinju, Uršnih selih in Žužemberku, najbolj pa izstopa Lož s Starim trgom ( $0,9 \%$ pozidanih površin). Skupaj zavzemajo dobrega pol hektara površin $(0,1 \%$ poseljenih površin). Več jih je v strnjenih delih naselij (0,2\%).

\section{Prometne površine}

Prometne površine vključujejo prometnice (ceste, poti, železnice) in parkirišča. Izločili smo prometne površine znotraj ograjenih industrijskih in drugih območij, ki služijo notranjim potrebam posameznih dejavnosti. Te prometne površine smo upoštevali v okviru ustrezne dejavnosti.

Po kategorizaciji Direkcije Republike Slovenije za ceste med razlikujemo:

- državne prometne površine, ki vključujejo avtoceste, hitre ceste, glavne ceste I. in II. reda ter regionalne ceste I., II. in III. reda in

- ostale prometne površine, ki vključujejo ostale javne ceste, kot so občinske ceste (lokalne ceste in javne poti) in zasebne ceste in poti (dovozi do objektov ter ceste, kolovozi in poti znotraj kmetijskih in zelenih površin v okviru poseljenega dela naselja).

V obravnavanih naseljih spada med prometne površine 114,91 ha površin, kar pomeni 5,1 \%-ni delež v okviru poseljenih površin $(3,6 \%-11,8 \%)$. Od teh površin jih med državne ceste spada le 14,4 ha ali 12,5 \%.

Posebej nas je zanimala razlika med strnjeno in nestrnjeno poseljenimi območji. V strnjeno pozidani Spodnji Besnici, ki jo lahko primerjamo z mestno poselitvijo, obsegajo pozidane površine dobri dve tretjini zemljišč, večji zeleni otoki $14,7 \%$, prometne površine pa kar 15,2 \%.

Na strnjeno poseljeno območje odpade 52,85 ha prometnic ali 9,2 \% njihove površine (4,8 \%-12,9\%), v nestrnjeno poseljenem območju pa jih je 62,06 ha ali 3,6\% (2,2\%-10,2\%). V nestrnjeno poseljenih območjih izstopa z izredno velikim deležem prometnih površin (10,2 \%) panonsko naselje Lipovci, ker skozenj teče državni koridor. Sicer pri gručastih naseljih prevladujejo deleži med 2 in $3 \%$. Vrednosti prek $4 \%$ v okviru nestrnjeno poseljenga dela imata zaradi svoje razloženosti le naselji Brdinje in Uršna sela, blizu je tudi Krčevina pri Vurbergu.

Na strnjeno območje odpade $46 \%$, na nestrnjeno območje pa $54 \%$ prometnih površin. Delež državnih cest od vseh prometnih površin je znotraj strnjeno in nestrnjeno poseljenega območja podoben (12,3 in 12,7\%).

Slika 10: Prometne površine v poseljenem delu naselja leta 2005.

Glej angleški del prispevka.

Slika 11: Delež državnih cest v okviru vseh prometnih površin v poseljenem delu naselja leta 2005.

Glej angleški del prispevka.

\section{Športna igrišča in parki}

Športna igrišča pokrivajo le 3 ha $(0,1 \%)$ vseh poseljenih površin. Najdemo jih le v 6 od 11 enot. Pogostejši so, kjer je nadpovprečno število delovnih mest (Ihan, Lipovci, Lož s Starim trgom), če je v naselju velik delež počitniških hišic (Uršna sela), ali če je v bližini večje mestno središče (Besnici).

Slika 12: Športna igrišča in parki v poseljenem delu naselja leta 2005.

Glej angleški del prispevka.

\section{Zelene in kmetijske površine}

Zelene in kmetijske površine vključujejo večje vrtove (širše in daljše od $17 \mathrm{~m}$ ), zelenice, parke in kmetijske površine (njive, travnike in pašnike) - vse znotraj poseljenega dela naselja. Vse strnjene gozdove in kmetijske površine smo namreč izvzeli iz obravnave.

V poseljenem območju je skupaj 1364,90 ha ali 59,9\% zelenih in kmetijskih površin $(47,6 \%-73,6 \%)$. Na strnjeno poseljeni del jih odpade 19,8\% (270,59 ha); znotraj tega območja zavzemajo 47,2\% površin $(38,3 \%-71,1 \%)$. Na nestrnjeno poseljeni del pa odpade $80,2 \%$ vseh zelenih in kmetijskih površin (1093,88 ha); znotraj nestrnjeno poseljenega območja zavzemajo zelene in kmetijske površine $64,2 \%$ površin (razpon: 47,8 \%-74,0\%). Naselja, ki imajo v okviru poseljenih površin najmanjši delež zelenih in kmetijskih površin, so: Brdinje, Spodnja in Zgornja Besnica ter Lož s Starim trgom. Pri prvih dveh je vzrok razloženost, zaradi česar vmesne zelene in kmetijske površine spadajo med strnjene in tako iz obravnave izpadejo, pri Ložu pa gre dejansko za gosto pozidanost. 
Slika 13: Zelene in kmetijske površine v poseljenem delu naselja leta 2005.

Glej angleški del prispevka.

\section{Gozdne površine}

$\mathrm{V}$ raziskavi smo upoštevali gozdne površine znotraj poseljenega dela naselja. Njihova površina znaša 491,10 ha, ali 21,6\% poseljenega območja. V strnjeno poseljenem delu je ta odstotek le 7,5\% (1,0\%-12,1\%), v nestrnjenem pa preseže eno četrtino - 26,3\% (2,9\%-43,9\%). Kot gozdna izstopajo naselja v hribovitem svetu - Spodnja in Zgornja Besnica in naselje samotnih kmetij Brdinje na Koroškem.

Slika 14: Gozdne površine v poseljenem delu naselja leta 2005.

Glej angleški del prispevka.

\section{Vodne površine}

V raziskavi smo upoštevali vodne površine znotraj poseljenega dela naselja, ki obsegajo 11,68 ha ali 0,5 \% poseljenega območja. Nekatera območja, zlasti kraška, sploh nimajo vodnih površin. Izjema je Žužemberk, kjer skozi strnjeno poseljeno območje teče alohtona Krka, ki zavzema kar 2,8 \% površin.

Slika 15: Vodne površine v poseljenem delu naselja leta 2005.

Glej angleški del prispevka.

\section{Družbenogospodarske značilnosti vzorca naselij}

Najpogostejši način določanja družbenogospodarskih značilnosti posameznih naselij je analiza delovno aktivnega prebivalstva $v$ naselju in analiza funkcij, ki jih ima naselje. Na podlagi podatkov iz popisa prebivalstva (2002) smo ugotavljali dnevno mobilnost prebivalcev, razmerja med zaposlenimi in delovnimi mesti v naselju ter vlogo, ki jo imajo v hierarhičnem omrežju naselij. Za natančnejše določanje dejavnostne sestave podjetij smo uporabili Poslovni register Slovenije (AJPES 2002).

Dnevna mobilnost delovno aktivnega prebivalstva je osnovni pokazatelj družbenih značilnosti posameznih naselij. Prikažemo jo z deležem vozačev (dnevnih migrantov) od celotnega delovno aktivnega prebivalstva, ki prebiva v določenem naselju. Dnevni delovni migrant je vsak delavec, ki potuje na delo v naselje, ki ni naselje bivanja. Slika 16 prikazuje vrednosti tega kazalnika za izbrani vzorec podeželskih naselij. Opazna je velika razlika med naseljema Lož in Stari trg pri Ložu, kjer je delež vozačev precej nižji kot v ostalih naseljih. Izrazito visoke vrednosti izkazujejo naselja Uršna sela, Zgornja in Spodnja Besnica ter Brdinje. V večini izbranih naselij število delovnih mest in njihova struktura nista v ravnotežju z delovno aktivnim prebivalstvom. To vodi v povečano dnevno mobilnost aktivnega prebivalstva. Podatki niso presenetljivi, saj kmetijstvo, nekoč poglavitna gospodarska panoga na podeželju, ne igra več vidne vloge. Aktivno prebivalstvo se zato zaposluje v mestnih naseljih.

Tudi pri našem vzorcu naselij se večina delovno aktivnih prebivalcev vozi v bližnja naselja višjega reda: iz Brdinj v Ravne (več kot 50 \%), iz Križa in Šepulj v Sežano (51 \%), iz Lipovcev v Mursko Soboto (52 \%), iz Uršnih sel v Novo mesto (75\%). Iz Velikih Lašč se večina (58 \%) vseh delovno aktivnih prebivalcev vozi v oddaljeno Ljubljano. Naš vzorec ima v povprečju med delovno aktivnimi prebivalci $74 \%$ vozačev, slovensko povprečje pa je 54,6\%.

Slika 16: Delež vozačev (dnevnih migrantov) od vseh delovno aktivnih prebivalcev.

Glej angleški del prispevka.

Za raziskavo je bil pomemben tudi podatek o delovno aktivnem prebivalstvu po naselju bivanja in po naselju dela (delovna mesta). Presežek delovnih mest nad delovno aktivnimi v naselju izkazujeta le naselji Lož-Stari trg in Žužemberk (slika 17). Posebno Lož-Stari trg pri Ložu ima visoko število delovnih mest v proizvodnem obratu Kovinoplastike Lož in predstavlja za bližnja naselja pomembno zaposlitveno središče. Večje zaposlitveno središče je tudi Žužemberk, ki zaposluje več delavcev kot je delovno aktivnih prebivalcev v naselju. Ostala naselja imajo manj delovnih mest in so izvorna območja delovno aktivnih prebivalcev. Zgornja in Spodnja Besnica, Uršna sela, Krčevina pri Vurbergu, Parecag in Brdinje imajo nizko število delovnih mest in velike tokove dnevne mobilnosti v bližnja zaposlitvena središča. 
Uporaben kazalnik je tudi lokacijska divergenca (LD), to je količnik delovno aktivnih prebivalcev po kraju bivanja in kraju dela. Izračuamo jo tako, da število delovno aktivnih prebivalcev po kraju bivanja (Z) delimo s številom delovno aktivnih prebivalcev po kraju dela (DM; število delovnih mest). Optimalno je število delavcev na določenem območju v ravnovesju $\mathrm{z}$ delovnimi mesti znotraj naselja, torej je vrednost lokacijske divergence enaka ena (Ravbar 2002, 18). Vrednost, ki je nižja od 1, pomeni prevlado delovnih mest nad zaposlenimi, višja od 1 pa prevlado zaposlenih nad delovnimi mesti v določenem naselju (glej preglednico 3). Razpon pri izbranih naseljih sega vse od 0,41 (Lož/Stari trg pri Ložu) do 8,1 (Zgornja in Spodnja Besnica). Naselja Lipovci, Ihan in Križ/Šepulje imajo bolj uravnoteženo lokacijsko divergenco zaradi posamičnih večjih industrijskih obratov: v Ihanu je živinorejski obrat, v Šepuljah mesnopredelovalni obrat, v Lipovcih pa farmacevtski proizvodni obrat.

Slika 17: Razmerje med številom zaposlenih in številom delovnih mest.

Glej angleški del prispevka.

Preglednica 3: Tipizacija ekspertnega vzorca podeželskih naselij.

\begin{tabular}{|c|c|c|c|c|c|c|c|}
\hline ime naselja & $\begin{array}{l}\text { število } \\
\text { zaposlenih }\end{array}$ & $\begin{array}{l}\text { število } \\
\text { delovnih } \\
\text { mest }\end{array}$ & $\begin{array}{l}\text { lokacijska } \\
\text { divergenca }\end{array}$ & $\begin{array}{l}\text { delež delovnih } \\
\text { mest, ki jih } \\
\text { zasedajo delavci, } \\
\text { prebivajoči } \\
\text { v istem naselju }\end{array}$ & $\begin{array}{l}\text { delež vozačev } \\
\text { od vseh delovno } \\
\text { aktivnih } \\
\text { prebivalcev }\end{array}$ & $\begin{array}{l}\text { stopnja } \\
\text { središčnosti } \\
\text { naselja } \\
\text { (Vrišer 1998). }\end{array}$ & tip naselja \\
\hline Žužemberk & 417 & 466 & 0,89 & 36,27 & 59,47 & 2. & I. \\
\hline Lož/Stari trg pri Ložu & 598 & 1451 & 0,41 & 28,12 & 31,78 & 2. & I. \\
\hline Velike Lašče & 278 & 215 & 1,29 & 31,16 & 75,9 & 2. & I. \\
\hline Križ/Šepulje & 275 & 187 & 1,47 & ni podatka & 80 & - & II. \\
\hline Lipovci & 460 & 227 & 2,03 & 32,60 & 83,91 & - & II. \\
\hline Ihan & 321 & 178 & 1,80 & 43,26 & 72,31 & 1. & II. \\
\hline Brdinje & 256 & 66 & 3,87 & 40,91 & 89,45 & - & III. \\
\hline Krčevina pri Vurbergu & 324 & 67 & 4,83 & 77,61 & 83,96 & 1. & III. \\
\hline Parecag & 390 & 102 & 3,82 & 74,51 & 80,51 & - & III. \\
\hline Uršna sela & 256 & 32 & 8,00 & 75,00 & 90,62 & 1. & III. \\
\hline Spodnja in Zgornja Besnica & 648 & 80 & 8,10 & 77,50 & 90,28 & 1. & III. \\
\hline
\end{tabular}

Družbenogospodarske značilnosti vzorca naselij opredelimo tudi s stopnjo središčnosti (centralnosti), ki predstavlja temeljne značilnosti prostorske organizacije družbe v Sloveniji. Po Vrišerju (1998) je v Sloveniji 612 središčnih naselij z različnimi funkcijami, ki zadovoljujejo ne le prebivalce naselij, temveč tudi uporabnike v njihovem zaledju. Najvišji položaj v hierarhičnem omrě̌ju naselij imajo Žužemberk, Stari trg pri Ložu in Velike Lašče, ki so središčna naselja 2. stopnje ali vicinalna središča z nekaterimi specializiranimi storitvami, kot so ambulanta, bančna podružnica, lekarna, policijska postaja in specializirane trgovine. Štiri naselja smo opredelili kot središča 1. stopnje, ki imajo nepopolno ali popolno osnovno šolo, trgovino z živili in so sedeži krajevnih skupnosti. Ostala naselja niso središčna naselja. Tudi drugi avtorji (Ravbar in ostali 2001; Cigale 2002) so naselja Žužemberk, Velike Lašče in Stari trg pri Ložu praviloma uvrščali v višjo kategorijo kot ostala podeželska naselja. Na podlagi izbranih podatkov lahko naselja iz vzorca podeželskih naselij uvrstimo v tri temeljne tipe (preglednica 3):

$\mathrm{V}$ prvem tipu so lokalna središča, ki so zaposlitveni center za okoliška manjša naselja in so hkrati tudi upravno središče (sedeži občin). V našem primeru sta to naselji Žužemberk, Lož/Stari trg pri Ložu ter deloma tudi Velike Lašče. Dejansko imajo razvite tudi določene upravne funkcije in predstavljajo cilj vozačev ožje okolice, Lož in Žužemberk pa imata tudi močno proizvodno funkcijo (industrijo). Suburbanizacija je zaradi geografske oddaljenosti in drugih dejavnikov (predvsem zaradi razvitih drugih funkcij) manj izrazita. Za ta naselja lahko $\mathrm{z}$ vidika bodoče rabe tal napovedujemo predvsem krepitev vloge oskrbnih in ostalih storitvenih dejavnosti (terciarnih dejavnosti) ter ostale javne infrastrukture. Širjenje stanovanjskih površin je manj intenzivno.

Naslednja večja skupina so naselja $\mathrm{z}$ omejeno zaposlitveno funkcijo. Zanje je značilno večje število dnevnih migrantov iz naselja, kot število vozačev, ki prihajajo v naselje. To so naselja, ki imajo poleg delovnih mest $\mathrm{v}$ kmetijstvu še manjše število delovnih mest $\mathrm{v}$ posameznih proizvodnih obratih, kar je zasluga preteklega policentričnega prostorskega razvoja. Kljub vsemu pa je večina prebivalcev poiskala delovno 
mesto zunaj naselja v bližnjih urbanih središčih. V to skupino lahko uvrstimo Križ, Šepulje, Ihan in Lipovce. Ta naselja so v neposredni bližini večjih urbanih središč in so administrativno ter z vidika oskrbe od njih povsem odvisna. Vzrok sprememb rabe tal je suburbanizacija, ki vodi k večjemu povpraševanju po bivalnih površinah in spremljajoči komunalni in prometni infrastrukturi, v manjši meri tudi ostalih funkcij oskrbe in storitev.

V zadnji, tretji skupini so naselja, ki zaposlitvene funkcije skoraj nimajo in so funkcionalno dokaj homogena: Zgornja Besnica, Spodnja Besnica, Parecag, Uršna sela, Krčevina pri Vurbergu in Brdinje. Redka delovna mesta $v$ naselju zapolnjujejo kmetje ali samostojni podjetniki, večina prebivalcev pa se dnevno vozi v urbana središča. Zgornja in Spodnja Besnica sta pod močnim vplivom Kranja in Ljubljane, Parecag obalnih mest, Uršna sela Novega mesta, Krčevina pri Vurbergu Maribora in Ptuja, Brdinje Raven na Koroškem. Vsa omenjena naselja so v območju močne suburbanizacije ter nastajanja vikendov, zidanic in ostalih oblik stalne ali nestalne poselitve. V teh naseljih je pričakovano nadaljnje širjenje izključno stanovanjskih površin in pripadajoče infrastrukture.

Struktura delovnih mest glede na omenjeno tipologijo naselij (preglednica 4) potrjuje, da imajo središčna naselja tipa I v povprečju podjetja z večjim številom zaposlenih, v naseljih tipa III pa prevladujejo poslovni subjekti z manj kot 4 zaposlenimi, predvsem samostojni podjetniki in manjša podjetja.

Preglednica 4: Delež podjetij in delež delovnih mest po velikostnih skupinah podjetij - po naseljih leta 2002 (AJPES 2002).

\begin{tabular}{lcccccccccc}
\hline \multicolumn{1}{c}{ delež podjetij } \\
\hline $\begin{array}{c}\text { 1 do 4 } \\
\text { zaposleni }\end{array}$ & 5 do 19 & 20 do 99 & 100+ & skupaj & $\begin{array}{c}\text { 1 do } 4 \\
\text { zaposleni }\end{array}$ & 5 do 19 & 20 do 99 & $100+$ & skupaj \\
\hline tip I & 78,8 & 13,1 & 6,6 & 1,5 & 100 & 5,4 & 9 & 21,6 & 64 & 100 \\
tip II & 84,2 & 10,5 & 2,6 & 2,6 & 100 & 12 & 12,3 & 22,9 & 52,8 & 100 \\
tip III & 93,6 & 5,8 & 0,6 & 0 & 100 & 57,5 & 30,2 & 12,3 & 0 & 100 \\
skupaj & 86,3 & 9,4 & 3,1 & 1,2 & 100 & 11,9 & 11,8 & 21,1 & 55,2 & 100 \\
\hline
\end{tabular}

Omenjene družbenogospodarske tipe podeželskih naselij lahko povežemo s spremembami v rabi tal med letoma 1992 in 2005. Pri vseh družbenogospodarskih tipih naselij je največ novozgrajenih površin v kategoriji »individualne stanovanjske gradnje«. Pri naseljih I. tipa izstopajo še nadpovprečne spremembe nestanovanjskih površin, saj gre za središčna naselja, ki imajo razvite tudi nestanovanjske funkcije, kot so oskrba, proizvodnja, rekreacija in druge (preglednica 5). Pri naseljih II. tipa so spremembe v nestanovanjski rabi pozidanih površin že manjše $(30,1 \%$ na celotnem poseljenem območju naselja), pri naseljih III. tipa pa zelo nizke (6,6\% na celotnem območju naselja). Individualna stanovanjska gradnja močno narašča v naseljih III. tipa, tako v nestrnjenem kot v strnjenem območju naselja (87 in $84 \%)$.

Indeksi sprememb (preglednica 6) so največji v naseljih II. (109,7) in III. tipa (109). Pri obeh omenjenih tipih naseljih rastejo predvsem nove površine v nestrnjenem delu. V središčnih naseljih I. tipa so indeksi sprememb nižji in enakomerno razporejeni glede na individualno stanovanjsko ter nestanovanjsko gradnjo.

V obdobju med letoma 1992 in 2005 absolutno najbolj naraščajo pozidane površine v naseljih III. tipa, kjer je suburbanizacija najbolj aktualna $\left(97.500 \mathrm{~m}^{2}\right)$, nekoliko manj v naseljih II. tipa $\left(78.600 \mathrm{~m}^{2}\right)$ in najmanj v naseljih I. tipa $\left(43.800 \mathrm{~m}^{2}\right)$. Absolutno gledano je največ novozgrajenih površin v strnjenem območju naselij, le pri naseljih III. tipa prevladujejo novozgrajene površine v nestrnjenem območju.

S primerjavo relativnih vrednosti (indeksov sprememb) pa ugotovimo, da naselja I. tipa izkazujejo najvišje spremembe v nestanovanjski in individualni stanovanjski gradnji (oba indeksa 105,7), naselja II. tipa pri individualni stanovanjski gradnji (indeks 109,9), naselja III. tipa pa v mešani gradnji. Indeks sprememb nakazuje, da se v vseh tipih naselij najbolj spreminja nestrnjeno poseljeno območje, manj pa strnjeno.

Ti kazalci spreminjanja rabe tal nakazujejo, da naselja I. tipa rastejo počasneje ker so že izoblikovana kot »podeželska urbanizirana naselja (Ravbar 1998). Naselja II. tipa so bolj odvisna od večjih mest v bližnji okolici in dejansko predstavljajo njihov obmestni prostor, medtem ko so naselja III. tipa hitro rastoča podeželska naselja, kamor se širi urbanizacija v sodobni »obliki naselij z manjšo gostoto poselitve« - suburbanizirana naselja. 
Preglednica 5: Novozgrajene pozidane površine v obdobju 1992 do 2005 po tipih naselij.

\begin{tabular}{|c|c|c|c|c|c|c|c|c|c|c|}
\hline & $\begin{array}{l}\text { stanovanjska } \\
\text { individualna } \\
\text { gradnja }\end{array}$ & $\begin{array}{l}\text { stanovanjska } \\
\text { blok. gradnja }\end{array}$ & $\begin{array}{l}\text { mešano } \\
\text { (stan. in } \\
\text { nestan.) }\end{array}$ & nestanovanjsko & skupaj & $\begin{array}{l}\text { stanov. } \\
\text { indiv. } \\
\text { gradnja }\end{array}$ & $\begin{array}{l}\text { stanov. } \\
\text { blok. } \\
\text { gradnja }\end{array}$ & $\begin{array}{l}\text { mešano } \\
\text { (stan. in } \\
\text { nestan.) }\end{array}$ & nestanovanjsko & skupaj \\
\hline strnjeno območje naselja & $m^{2}$ & $m^{2}$ & $m^{2}$ & $m^{2}$ & $m^{2}$ & $\%$ & $\%$ & $\%$ & $\%$ & $\%$ \\
\hline $\begin{array}{l}\text { I. } \\
\text { II. } \\
\text { III. } \\
\text { vsa naselja }\end{array}$ & $\begin{array}{l}21667 \\
43103 \\
17977 \\
82747\end{array}$ & $\begin{array}{r}245 \\
1916 \\
0 \\
2161\end{array}$ & $\begin{array}{l}2038 \\
3507 \\
2962 \\
8507\end{array}$ & $\begin{array}{r}11983 \\
14267 \\
2938 \\
29188\end{array}$ & $\begin{array}{r}35933 \\
62793 \\
23877 \\
122603 \\
\end{array}$ & $\begin{array}{l}60,3 \\
68,6 \\
75,3 \\
67,5\end{array}$ & $\begin{array}{l}0,7 \\
3,1 \\
0 \\
1,8\end{array}$ & $\begin{array}{r}5,7 \\
5,6 \\
12,4 \\
6,9\end{array}$ & $\begin{array}{l}33,3 \\
22,7 \\
12,3 \\
23,8\end{array}$ & $\begin{array}{l}100 \\
100 \\
100 \\
100\end{array}$ \\
\hline \multicolumn{2}{|c|}{ nestrnjeno območje naselja m² } & $m^{2}$ & $m^{2}$ & $m^{2}$ & $\mathrm{~m}^{2}$ & $\%$ & $\%$ & $\%$ & $\%$ & $\%$ \\
\hline $\begin{array}{l}\text { I. } \\
\text { II. } \\
\text { III. } \\
\text { vsa naselja }\end{array}$ & $\begin{array}{r}3700 \\
6405 \\
64255 \\
74360\end{array}$ & $\begin{array}{l}0 \\
0 \\
0 \\
0\end{array}$ & $\begin{array}{r}322 \\
0 \\
5863 \\
6185\end{array}$ & $\begin{array}{r}3878 \\
9392 \\
3446 \\
16716\end{array}$ & $\begin{array}{r}7900 \\
15797 \\
73564 \\
97261\end{array}$ & $\begin{array}{l}46,8 \\
40,5 \\
87,3 \\
76,5\end{array}$ & $\begin{array}{l}0 \\
0 \\
0 \\
0\end{array}$ & $\begin{array}{l}4,1 \\
0 \\
8 \\
6,4\end{array}$ & $\begin{array}{r}49,1 \\
59,5 \\
4,7 \\
17,2\end{array}$ & $\begin{array}{l}100 \\
100 \\
100 \\
100\end{array}$ \\
\hline \multicolumn{2}{|c|}{ celotno poseljeno območje naselja } & $\mathrm{m}^{2}$ & $\mathrm{~m}^{2}$ & $m^{2}$ & $\mathrm{~m}^{2}$ & $\mathrm{~m}^{2}$ & $\%$ & $\%$ & $\%$ & $\% \%$ \\
\hline $\begin{array}{l}\text { I. } \\
\text { II. } \\
\text { III. } \\
\text { vsa naselja }\end{array}$ & $\begin{array}{r}25367 \\
49508 \\
82232 \\
157107\end{array}$ & $\begin{array}{r}245 \\
1916 \\
0 \\
2161\end{array}$ & $\begin{array}{r}2360 \\
3507 \\
8825 \\
14692\end{array}$ & $\begin{array}{r}15861 \\
23659 \\
6384 \\
45904\end{array}$ & $\begin{array}{r}43833 \\
78590 \\
97441 \\
219864\end{array}$ & $\begin{array}{l}57,9 \\
63 \\
84,4 \\
71,5\end{array}$ & $\begin{array}{l}0,6 \\
2,4 \\
0 \\
1\end{array}$ & $\begin{array}{l}5,4 \\
4,5 \\
9,1 \\
6,7\end{array}$ & $\begin{array}{r}36,2 \\
30,1 \\
6,6 \\
20,9\end{array}$ & $\begin{array}{l}100 \\
100 \\
100 \\
100\end{array}$ \\
\hline
\end{tabular}


Maja Topole, David Bole, Franci Petek, Peter Repolusk, Prostorske in funkcijske spremembe pozidanih zemljišč v izbranih slovenskih ...

Preglednica 6: Indeks spremembe površine posameznih tipov pozidanih površin v obdobju 2005/1992 po tipih naselij

\begin{tabular}{|c|c|c|c|c|c|}
\hline & $\begin{array}{l}\text { stanov. indiv. } \\
\text { gradnja }\end{array}$ & $\begin{array}{l}\text { stanov. blok. } \\
\text { gradnja }\end{array}$ & $\begin{array}{l}\text { mešano (stan. } \\
\text { in nestan.) }\end{array}$ & nestanovanjsko & skupaj \\
\hline \multicolumn{6}{|c|}{ strnjeno območje naselja } \\
\hline l. & 105,4 & 101,6 & 104,2 & 106 & 105,4 \\
\hline II. & 109 & 266,6 & 107,3 & 106,9 & 108,5 \\
\hline III. & 104,2 & 100 & 106,5 & 108,3 & 104,7 \\
\hline vsa naselja & 106,3 & 110,6 & 106 & 106,6 & 106,4 \\
\hline \multicolumn{6}{|c|}{ nestrnjeno območje naselja } \\
\hline l. & 108 & - & 105,8 & 105 & 106,1 \\
\hline ॥. & 127,5 & - & 100 & 120,1 & 121,7 \\
\hline III. & 113,5 & 100 & 116,5 & 105,8 & 112,9 \\
\hline vsa naselja & 113,6 & 100 & 114,1 & 109,1 & 112,6 \\
\hline \multicolumn{6}{|c|}{ celotno poseljeno območje naselje } \\
\hline l. & 105,7 & 101,6 & 104,4 & 105,7 & 105,5 \\
\hline II. & 109,9 & 266,6 & 106,9 & 109,3 & 109,7 \\
\hline III. & 109,1 & 100 & 110,9 & 106,7 & 109 \\
\hline vsa naselja & 108,5 & 110 & 107,9 & 107,3 & 108,2 \\
\hline
\end{tabular}

\section{Raba tal in gostota delovnih mest}

V tem poglavju opisujemo površine, namenjene posameznim skupinam dejavnosti ter izračun gostote delovnih mest za posamezno dejavnost na hektar po naseljih. Želeli smo ugotoviti poglavitne trende razvoja delovnih mest v slovenskih podeželskih naseljih ter razlike med tipi podeželskih naselij, ki jih je zajel ekspertni vzorec.

Pri obravnavi površin, namenjenih posameznim dejavnostim, smo uporabili razdelitev dejavnosti po enotni klasifikaciji dejavnosti (EKD). Dejavnosti smo za potrebe naše analize združili v osem skupin (preglednica 7).

Preglednica 7: Klasifikacije dejavnosti.

\begin{tabular}{|c|c|c|}
\hline Šifra dejavnosti & dejavnost po EKD & skupine dejavnosti v naši analizi \\
\hline $\begin{array}{l}A \\
B\end{array}$ & $\begin{array}{l}\text { kmetijstvo, lov, gozdarstvo } \\
\text { ribištvo in ribiške storitve }\end{array}$ & kmetijske dejavnosti \\
\hline $\begin{array}{l}\text { C } \\
D \\
E\end{array}$ & $\begin{array}{l}\text { rudarstvo } \\
\text { predelovalne dejavnosti } \\
\text { oskrba z el. energijo, plinom in vodo }\end{array}$ & predelovalne dejavnosti \\
\hline $\mathrm{F}$ & gradbeništvo & gradbeništvo \\
\hline G & trgovina & trgovina \\
\hline H & gostinstvo & gostinstvo \\
\hline I & promet, skladiščenje, zveze & promet \\
\hline $\begin{array}{l}\mathrm{L} \\
\mathrm{M} \\
\mathrm{N}\end{array}$ & $\begin{array}{l}\text { javna uprava, obramba, soc. zavarovanje } \\
\text { izobraževanje } \\
\text { zdravstvo, socialno varstvo }\end{array}$ & javne dejavnosti \\
\hline $\begin{array}{l}J \\
K \\
0\end{array}$ & $\begin{array}{l}\text { finančno posredništvo } \\
\text { nepremičnine, najem, poslovne storitve } \\
\text { dr. javne, skupne in osebne storitve }\end{array}$ & druge storitvene dejavnosti \\
\hline
\end{tabular}

Pri analizi delovnih mest, njihovem razvrščanju v skupine in izračunih glede na površine, namenjene posameznim skupinam dejavnosti, so se zaradi neusklajenosti metodologije različnih virov podatkov (Popis prebivalstva 2002; AJPES; terensko delo) pojavljale naslednje težave oziroma potrebe po posplošitvah, korekcijah, pogosto tudi ocenah: 
- metodologiji določitve skupine »javne dejavnosti« pri površinah nismo mogli povsem slediti pri določitvi delovnih mest po skupinah dejavnosti iz popisa prebivalstva 2002 (SURS); dejavnosti javne higiene ter kulture so pri površinah štete k javnim dejavnostim, popisna metodologija oziroma dostopni popisni podatki pa te dejavnosti uvrščajo med »druge storitve«; menimo, da delovna mesta iz teh skupin na podeželju niso tako pogosta kot $\mathrm{v}$ urbanih naseljih (to velja tudi za nekdanja komunalna podjetja in njihove naslednike, ki so večinoma zgoščeni v mestih oziroma centrih upravnih enot) in da se zaradi tega izračun gostote delovnih mest na površino ne spreminja bistveno;

- zaradi varovanja osebnih podatkov nismo imeli dostopa do podatkov o zasebnih kmetih in kmetijskih gospodarstvih oziroma njihovih površinah, ki ne glede na urbaniziranost obravnavanih naselij še vedno predstavljajo 8,4\% v naselju zaposlenega prebivalstva (popis 2002, SURS); zaradi tega nismo mogli izračunati gostote delovnih mest za kmetijske dejavnosti;

- med popisom prebivalstva in terenskim delom so pretekla tri leta, zato se v nekaj primerih zgodi, da smo na terenu ugotovili površine z dejavnostmi, popis pa tam ne beleži zaposlenih ali obratno; pri vseh takih primerih je v preglednici 8 navedena gostota za delovna mesta 0 ;

- v viru AJPES (2002) so v nekaterih primerih poslovni subjekti (upoštevali smo samo podjetja različnih tipov, ki imajo delovna mesta) oziroma njihove podružnice ali poslovalnice navedeni v naseljih, kjer ima podjetje uradni sedež, ne pa v naseljih, kjer gospodarska dejavnost dejansko poteka; kjer je bilo mogoče, smo podatek korigirali s terenskim delom.

Ker so v uvodni in vseh drugih preglednicah pozidane površine, namenjene gospodarskim dejavnostim, prikazane na način, kot je razloženo v metodološkem uvodu o zajemu podatkov o stavbah z letalskih in ortofotografskih posnetkov, moramo upoštevati, da bi bile površine in gostote delovnih mest, če bi jih prikazovali kot parcelne podatke, nekoliko nižje. Iz analize gostot smo izločili površine oziroma objekte z dejavnostmi, kot so društva, združenja, športni in drugi klubi, lovske družine, verska združenja, ki ne nudijo delovnih mest, najpogosteje pa so njihovi sedeži locirani v stanovanjskih hišah.

V preglednici 8 so prikazane gostote delovnih mest na 1 ha površine za posamezne dejavnosti in naselja. Podatki v preglednici terjajo nekatere dodatne razlage:

- zaradi nedostopnosti podatkov o površinah in delovnih mestih na zasebnih kmetijah smo izračun za kmetijske in sorodne panoge (ribištvo, gozdarstvo) izločili iz preglednic, saj bi bila ocenjena na podlagi drugih virov previsoka; iz izračuna so bile tako izločene površine prašičje farme v naselju Ihan ter površine gospodarske dejavnosti kmetijske zadruge v Velikih Laščah, saj obe sodita v področje dejavnosti kmetijstva; obe dejavnosti pa se od družinskega kmetovanja bistveno razlikujeta, v primeru Ihana gre za dejavnost, ki je po delovnem postopku podobna predelovalnim dejavnostim, v primeru Velikih

Preglednica 8: Gostota delovnih mest (na ha) po dejavnostih (glede na površine, namenjene dejavnosti) brez kmetijskih dejavnosti po naseljih leta 2005

\begin{tabular}{|c|c|c|c|c|c|c|c|c|}
\hline & $\begin{array}{c}\text { predelovalne } \\
\text { dejavnosti }\end{array}$ & gradbeništvo & trgovina & gostinstvo & promet & $\begin{array}{c}\text { javne } \\
\text { dejavnosti }\end{array}$ & $\begin{array}{l}\text { druge } \\
\text { storitve }\end{array}$ & skupaj \\
\hline & $\begin{array}{l}\text { število } \\
\text { delovnih } \\
\text { mest/ha }\end{array}$ & $\begin{array}{l}\text { število } \\
\text { delovnih } \\
\text { mest/ha }\end{array}$ & $\begin{array}{l}\text { število } \\
\text { delovnih } \\
\text { mest/ha }\end{array}$ & $\begin{array}{l}\text { število } \\
\text { delovnih } \\
\text { mest/ha }\end{array}$ & $\begin{array}{l}\text { število } \\
\text { delovnih } \\
\text { mest/ha }\end{array}$ & $\begin{array}{l}\text { število } \\
\text { delovnih } \\
\text { mest/ha }\end{array}$ & $\begin{array}{l}\text { število } \\
\text { delovnih } \\
\text { mest/ha }\end{array}$ & $\begin{array}{l}\text { število } \\
\text { delovnih } \\
\text { mest/ha }\end{array}$ \\
\hline \multicolumn{9}{|l|}{ Spodnja in } \\
\hline Zgornja Besnica & 20,09 & 21,93 & 16,42 & 84,99 & 34,42 & 2,81 & 44,13 & 20,6 \\
\hline Ihan & 21,38 & 15,94 & 8,55 & 29,67 & 28,86 & 11,01 & 54,27 & 13,17 \\
\hline Brdinje & 47,15 & 55,33 & 12 & 0 & 0 & 0 & 39,17 & 35,59 \\
\hline Lipovci & 37,72 & 26 & 42,6 & 19,05 & 13,79 & 9,64 & 9,44 & 24,25 \\
\hline Krčevina pri Vurbergu & 26,4 & 35,43 & 10,78 & 87,72 & 43,9 & 44,61 & 0 & 41,16 \\
\hline Uršna sela & 40,35 & 19,55 & 83,75 & 0 & 14,48 & 7,24 & 15,22 & 24,88 \\
\hline Žužemberk & 1653,08 & 38,55 & 106,22 & 245,9 & 83,91 & 47,01 & 21,57 & 81,68 \\
\hline Velike Lašče & 12,44 & 48,47 & 24,23 & 53,19 & 43,57 & 49,92 & 52,32 & 31,29 \\
\hline \multicolumn{9}{|l|}{ Lož in Stari trq } \\
\hline pri Ložu & 146,11 & 23,05 & 155,04 & 65,86 & 47,2 & 26,53 & 104,17 & 72,62 \\
\hline Parecag & 91,3 & 63,43 & 15,92 & 20,98 & 58,48 & 63,05 & 130,51 & 32,87 \\
\hline Križ in Šepulje & 107,2 & 21,84 & 24,99 & 26,5 & 29,04 & 12,72 & 24,62 & 51,33 \\
\hline vsa naselja skupaj & 104,36 & 34,61 & 31,32 & 41,87 & 42,52 & 26,8 & 39,74 & 47,52 \\
\hline
\end{tabular}


Lašč pa trgovinski dejavnosti; vključitev površin in delovnih mest obeh dejavnosti, kar bi bilo realneje, bi pomenila, da bi se skupna gostota delovnih mest v naselju Ihan povečala za dvakrat (na okrog 25 delovnih mest na ha), v Velikih Laščah pa približno za četrtino (na okrog 40 delovnih mest na ha);

- v preglednici o gostoti delovnih mest v predelovalnih dejavnostih je visoka vrednost za Žužemberk 1653; vrednosti v ostalih naseljih se gibljejo med 12 in 146, povprečje za vsa naselja je 104; vzrok je ta, da so na naslovu industrijskega podjetja tudi številne druge dejavnosti, ki ne sodijo k predelovalnim, zato je površina metodološko šteta k površinam $z$ več dejavnostmi; vrednost je previsoka vsaj za desetkrat, če upoštevamo vrednost za Lož-Stari trg s sorodno gospodarsko sestavo; na skupno gostoto delovnih mest $\mathrm{v}$ naselju naveden računski problem nima vpliva;

- gostote delovnih mest za dejavnost prometa, gradbene dejavnosti in druge storitve so previsoke, saj gre najpogosteje za samostojne podjetnike (avtoprevoznike, zidarje, lastnike gradbene mehanizacije, samozaposlene s področij zasebnega zdravstva, odvetništva, finančnega svetovanja, samostojne kulturne delavce), kjer doma locirane delovne površine redko vsebujejo kaj drugega kot povečana parkirišča za vozila ali le spremenjene ali prilagojene prostore stanovanjske hiše; pogosto gre le za sedež podjetja, zaposleni pa opravljajo večino dela zunaj naselja bivanja. Ker so številna majhna podjetja iz omenjenih skupin pogosta v manjših naseljih razpršene poselitve in novejše suburbanizacije, je podatek o gostoti delovnih mest (v primerjavi s središčnimi naselji in zaposlitvenimi centri) realno nižji. To še posebej velja za naselji Krčevina pri Vurbergu (več avtoprevoznikov) in Brdinje (več samostojnih podjetnikov s področja gradbeništva).

Če poleg podatkov iz preglednice upoštevamo še zgoraj navedene korekcije, so splošni zaključki o gostoti delovnih mest naslednji:

- največja gostota delovnih mest je v predelovalnih dejavnostih - tudi če upoštevamo korekcijo za Žužemberk, še vedno znaša 92 delovnih mest na ha;

- predelovalnim dejavnostim objektivno sledita gostinstvo in trgovina;

- gostota delovnih mest za druge skupine dejavnosti je zaradi prej povedanega nižja, saj številna podjetja za svoje delovanje ne potrebujejo posebnih površin v naselju in je delovanje zaposlenih manj vezano na območje naselja;

- največja gostota delovnih mest je v naseljih z velikimi ali večjim številom srednje velikih podjetij (Žužemberk, Lož-Stari trg, Križ-Šepulje in Velike Lašče);

- nižje gostote delovnih mest so v razloženih manjših naseljih z manjšim številom središčnih dejavnosti in večjim številom samostojnih podjetnikov ali manjših podjetij drugega tipa.

V preglednici 9 in na sliki 18 so gostote delovnih mest po dejavnostih predstavljene po skupinah naselij, kot so bile predstavljene v opredelitvi ekspertnega vzorca obravnavanih naselij: tip I - središčna naselja (Žužemberk, Lož-Stari trg pri Ložu, Velike Lašče), tip II - zaposlitvena središča (Lipovci, Ihan, Križ-Šepulje) in tip III - druga naselja (Spodnja in Zgornja Besnica, Brdinje, Krčevina pri Vurbergu, Uršna sela, Parecag).

Preglednica 9: Gostota delovnih mest po dejavnostih (glede na površine, namenjene dejavnosti) brez kmetijskih dejavnosti (l. 2005).

\begin{tabular}{|c|c|c|c|c|c|c|c|c|}
\hline & $\begin{array}{l}\text { predelov. dejav. } \\
\text { in rudarstvo }\end{array}$ & gradbeništvo & trgovina & gostinstvo & promet & $\begin{array}{c}\text { javne } \\
\text { dejavnosti }\end{array}$ & $\begin{array}{l}\text { druge storitvene } \\
\text { dejavnosti }\end{array}$ & skupaj \\
\hline & $\begin{array}{l}\text { delovnih } \\
\text { mest/ha }\end{array}$ & $\begin{array}{l}\text { delovnih } \\
\text { mest/ha }\end{array}$ & $\begin{array}{l}\text { delovnih } \\
\text { mest/ha }\end{array}$ & $\begin{array}{l}\text { delovnih } \\
\text { mest/ha }\end{array}$ & $\begin{array}{l}\text { delovnih } \\
\text { mest/ha }\end{array}$ & $\begin{array}{l}\text { delovnih } \\
\text { mest/ha }\end{array}$ & $\begin{array}{l}\text { delovnih } \\
\text { mest/ha }\end{array}$ & $\begin{array}{l}\text { delovnih } \\
\text { mest/ha }\end{array}$ \\
\hline tip I. & 144,97 & 34,66 & 82,28 & 84,43 & 70,64 & 40,09 & 60,51 & 67,22 \\
\hline tip II. & 47,98 & 21,67 & 15,78 & 24,38 & 23,29 & 10,58 & 21,1 & 25,31 \\
\hline tip III. & 36,77 & 42,83 & 17,37 & 29,03 & 32,14 & 11,57 & 42,36 & 29,47 \\
\hline vsa naselja & 104,36 & 34,61 & 31,32 & 41,87 & 42,52 & 26,8 & 39,74 & 47,52 \\
\hline
\end{tabular}

Slika 18: Gostota delovnih mest po posameznih dejavnostih (brez kmetijstva) in po tipu naselja leta 2005.

Glej angleški del prispevka.

Združevanje podatkov po tipih naselij nekoliko posploši podobo o gostotah delovnih mest. Občinska središča (središčna naselja) imajo največjo skupno gostoto delovnih mest in tudi največjo gostoto pri večini dejavnosti, zlasti pri predelovalnih. Tudi tip III izkazuje večje skupno gostoto delovnih mest in za 
večino dejavnosti, kar je posledica že omenjene previsoke izračunane vrednosti gostot za dejavnosti gradbeništva, prometa in drugih storitev, pri katerih so v preglednici 9 med tipoma II in III tudi največje razlike.

Podjetja (in drugi poslovni subjekti z delovnimi mesti) so v obravnavanih naseljih pretežno majhna. Manj kot 20 zaposlenih ima kar $96 \%$ podjetij, manj kot 5 pa $86 \%$. Naselja Spodnja in Zgornja Besnica, Brdinje, Uršna sela in Parecag imajo vsa delovna mesta v podjetjih $\mathrm{z}$ manj kot 20 zaposlenimi. $\mathrm{V}$ ostalih naseljih je večina delovnih mest $\mathrm{v}$ podjetjih $\mathrm{z}$ več kot 20 zaposlenimi, največ (nad dve tretjini) v središčnih naseljih in zaposlitvenih centrih Lož-Stari trg, Lipovci, Križ-Šepulje in Žužemberk (sliki 19 in 20). Največ majhnih podjetij je $\mathrm{v}$ dejavnostih gradbeništva, prometa, trgovine in drugih storitev. Zgostitev tovrstnih podjetij, predvsem pa delovnih mest, je značilna $\mathrm{v}$ manjših naseljih $\mathrm{z}$ razpršenim tipom poselitve, ki v zadnjem obdobju rastejo zaradi priseljevanja prebivalcev iz bližnjih mestnih naselij.

Slika 19: Struktura podjetij po velikosti (število delovnih mest) v \% - po naseljih leta 2002 (AJPES).

Glej angleški del prispevka.

Slika 20: Delež delovnih mest glede na velikost podjetja - po naseljih leta (AJPES 2002).

Glej angleški del prispevka.

\section{Spremembe rabe tal v obdobju od 1992 do 2005}

V Sloveniji suburbanizacijo spremlja tudi selitev nekaterih gospodarskih dejavnosti na cenejša podeželska zemljišča. S tem prihaja do zametkov mešanja namenske rabe podeželja. Podeželska območja $\mathrm{z}$ večjimi gostotami delovnih mest so zaenkrat še redka, a ta proces se že odraža v nižji stopnji zmanjševanja števila prebivalstva v okolici teh naselij (Kladnik in Ravbar 2003).

V obdobju od leta 1992 do 2005 so se pozidane površine v vseh enajstih naseljih povečale za 8,2\% ali 22 ha (preglednici 10 in 11). Največ ali $71 \%$ novih površin je bilo namenjenih izgradnji stanovanj, $21 \%$ pa izgradnji nestanovanjskih objektov. Preostanek so predvsem novi objekti mešane stanovanjsko-nestanovanjske funkcije. $\mathrm{V}$ relativnem obsegu rasti površin med posameznimi tipi gradnje (individualna stanovanjska, blokovna stanovanjska, mešana ter nestanovanjska gradnja) ni pomembnejših razlik. Površine posameznih tipov so se povečale za 7,3-10\%. Največjo dinamiko izkazuje blokovna gradnja, vendar gre v tem primeru za zelo majhne površine (skupaj 2,4 ha ali $0,8 \%$ pozidanih površin). Stanovanjska gradnja v splošnem izkazuje nekoliko višjo stopnjo relativne rasti, kar je v neposredni povezavi s priseljevanjem prebivalstva, saj je za velik del obravnavanih naselij značilno, da sodijo v neposredno gravitacijsko zaledje večjih urbanih središč.

Slika 21: Struktura v obdobju 1992-2005 novopozidanih površin v strnjeno poseljenem delu po naseljih. Glej angleški del prispevka.

Slika 22: Struktura v obdobju 1992-2005 novopozidanih površin v nestrnjeno poseljenem delu po naseljih. Glej angleški del prispevka.

Slika 23: Struktura v obdobju 1992-2005 novopozidanih površin v celotnem poseljenem delu po naseljih. Glej angleški del prispevka.

Med obravnavanimi naselji so precejšnje razlike. Najbolj intenzivna je bila gradnja v naseljih s priseljevanjem prebivalstva (močna stanovanjska in nestanovanjsko gradnja: Brdinje, Križ-Šepulje, Velike Lašče) in v naseljih s priseljevanjem prebivalstva (močna stanovanjska in mešana gradnja: Krčevina pri Vurbergu);

Gradnja je bila manj intenzivna v naseljih, ki jih je suburbanizacija s priseljevanjem prebivalstva zajela že pred letom 1990 (Spodnja in Zgornja Besnica, Ihan), v naseljih z znaki zastoja v demografskem in gospodarskem razvoju (Uršna sela, Lipovci) ter v večjih naseljih, ki imajo značilnosti majhnih urbanih središč, iz katerih se del prebivalstva seli v sosednja manjša naselja (Lož-Stari trg in Žužemberk).

Velike razlike $\mathrm{v}$ značilnostih gradnje so tudi med strnjenimi in nestrnjenimi deli znotraj naselij. V strnjenih delih naselij predstavlja stanovanjska gradnja $67,5 \%$ celotne nove pozidave, v nestrnjenih pa 76,5\%. Nasprotno predstavlja nestanovanjska gradnja 23,8 \% novogradenj v strnjenih in 17,2 \% v nestrnjenih delih naselij. Delež mešane gradnje je v obeh primerih zelo podoben $-6,9$ in $6,4 \%$. 
Preglednica 10: Novopozidane površine v obdobju 1992 do 2005 po naseljih.

\begin{tabular}{|c|c|c|c|c|c|c|c|c|c|c|c|}
\hline & ime naselja & $\begin{array}{l}\text { stanov. } \\
\text { individ. } \\
\text { gradnja }\end{array}$ & $\begin{array}{l}\text { stanov. } \\
\text { blokovna } \\
\text { gradnja }\end{array}$ & $\begin{array}{l}\text { mešano } \\
\text { stanov. in } \\
\text { nestanovanjsko }\end{array}$ & nestanovanjsko & $\begin{array}{l}\text { skupaj } \\
\text { gradnja }\end{array}$ & $\begin{array}{l}\text { stanov. } \\
\text { individ. } \\
\text { gradnja }\end{array}$ & $\begin{array}{l}\text { stanov. } \\
\text { blokovna } \\
\text { nestanovanjsko }\end{array}$ & $\begin{array}{l}\text { mešano } \\
\text { stanov. in }\end{array}$ & nestanovanjsko & skupaj \\
\hline A & STRNJENO OBMOČJE NASELJA & $\mathrm{m}^{2}$ & $\mathrm{~m}^{2}$ & $\mathrm{~m}^{2}$ & $\mathrm{~m}^{2}$ & $\mathrm{~m}^{2}$ & delež v \% & delež v \% & delež v \% & delež v \% & delež v \% \\
\hline 2 & Spodnja in Zgornja Besnica & 8658 & 0 & 763 & 1127 & 10548 & 82,1 & 0 & 7,2 & 10,7 & 100 \\
\hline 2 & Ihan & 4424 & 1916 & 1905 & 570 & 8815 & 50,2 & 21,7 & 21,6 & 6,5 & 100 \\
\hline 3 & Brdinje & 1236 & 0 & 85 & 0 & 1321 & 93,6 & 0 & 6,4 & 0 & 100 \\
\hline 4 & Lipovci & 14045 & 0 & 0 & 7216 & 21261 & 66,1 & 0 & 0 & 33,9 & 100 \\
\hline 5 & Krčevina pri Vurbergu & 310 & 0 & 0 & 0 & 310 & 100 & 0 & 0 & 0 & 100 \\
\hline 6 & Uršna Sela & 5570 & 0 & 182 & 215 & 5967 & 93,3 & 0 & 3,1 & 3,6 & 100 \\
\hline 7 & Žužemberk & 9220 & 0 & 1207 & 4372 & 14799 & 62,3 & 0 & 8,2 & 29,5 & 100 \\
\hline 8 & Velike Lašče & 6856 & 0 & 387 & 5130 & 12373 & 55,4 & 0 & 3,1 & 41,5 & 100 \\
\hline 9 & Lož in Stari trg pri L. & 5591 & 245 & 444 & 2481 & 8761 & 63,8 & 2,8 & 5,1 & 28,3 & 100 \\
\hline 10 & Parecag & 2203 & 0 & 1932 & 1596 & 5731 & 38,4 & 0 & 33,7 & 27,8 & 100 \\
\hline 11 & Križ in Šepulje & 24634 & 0 & 1602 & 6481 & 32717 & 75,3 & 0 & 4,9 & 19,8 & 100 \\
\hline$\Sigma$ & skupaj & 82747 & 2161 & 8507 & 29188 & 122603 & 67,5 & 1,8 & 6,9 & 23,8 & 100 \\
\hline $\mathrm{B}$ & NESTRNJENO OBMOČJE NASELJA & $m^{2}$ & $m^{2}$ & $\mathrm{~m}^{2}$ & $\mathrm{~m}^{2}$ & $\mathrm{~m}^{2}$ & delež v \% & delež v \% & delež v \% & delež v \% & delež v \% \\
\hline 1 & Spodnja in Zgornja Besnica & 8442 & 0 & 1003 & 917 & 10362 & 81,5 & 0 & 9,7 & 8,8 & 100 \\
\hline 2 & Ihan & 1146 & 0 & 0 & 3916 & 5062 & 22,6 & 0 & 0 & 77,4 & 100 \\
\hline 3 & Brdinje & 15940 & 0 & 644 & 1299 & 17883 & 89,1 & 0 & 3,6 & 7,3 & 100 \\
\hline 4 & Lipovci & 6 & 0 & 0 & 5205 & 5211 & 0,1 & 0 & 0 & 99,9 & 100 \\
\hline 5 & Krčevina pri Vurbergu & 28345 & 0 & 2147 & 882 & 31374 & 90,3 & 0 & 6,8 & 2,8 & 100 \\
\hline 6 & Uršna Sela & 8389 & 0 & 1398 & 348 & 10135 & 82,8 & 0 & 13,8 & 3,4 & 100 \\
\hline 7 & Žužemberk & 1501 & 0 & 0 & 818 & 2319 & 64,7 & 0 & 0 & 35,3 & 100 \\
\hline 8 & Velike Lašče & 1906 & 0 & 322 & 2191 & 4419 & 43,1 & 0 & 7,3 & 49,6 & 100 \\
\hline 9 & Lož in Stari trg pri L. & 293 & 0 & 0 & 869 & 1162 & 25,2 & 0 & 0 & 74,8 & 100 \\
\hline 10 & Parecag & 3139 & 0 & 671 & 0 & 3810 & 82,4 & 0 & 17,6 & 0 & 100 \\
\hline 11 & Križ in Šepulje & 5253 & 0 & 0 & 271 & 5524 & 95,1 & 0 & 0 & 4,9 & 100 \\
\hline$\sum$ & skupaj & 74360 & 0 & 6185 & 16716 & 97261 & 76,5 & 0 & 6,4 & 17,2 & 100 \\
\hline $\mathrm{C}$ & VSE POSELJENO OBMOČJE NASELJA & $\mathrm{m}^{2}$ & $\mathrm{~m}^{2}$ & $\mathrm{~m}^{2}$ & $\mathrm{~m}^{2}$ & $\mathrm{~m}^{2}$ & delež v \% & delež v \% & delež v \% & delež v \% & delež v \% \\
\hline 1 & Spodnja in Zgornja Besnica & 17100 & 0 & 1766 & 2044 & 20910 & 81,8 & 0 & 8,4 & 9,8 & 100 \\
\hline 2 & Ihan & 5570 & 1916 & 1905 & 4486 & 13877 & 40,1 & 13,8 & 13,7 & 32,3 & 100 \\
\hline 3 & Brdinje & 17176 & 0 & 729 & 1299 & 19204 & 89,4 & 0 & 3,8 & 6,8 & 100 \\
\hline 4 & Lipovci & 14051 & 0 & 0 & 12421 & 26472 & 53,1 & 0 & 0 & 46,9 & 100 \\
\hline 5 & Krčevina pri Vurbergu & 28655 & 0 & 2147 & 882 & 31684 & 90,4 & 0 & 6,8 & 2,8 & 100 \\
\hline 6 & Uršna Sela & 13959 & 0 & 1580 & 563 & 16102 & 86,7 & 0 & 9,8 & 3,5 & 100 \\
\hline 7 & Žužemberk & 10721 & 0 & 1207 & 5190 & 17118 & 62,6 & 0 & 7,1 & 30,3 & 100 \\
\hline 8 & Velike Lašče & 8762 & 0 & 709 & 7321 & 16792 & 52,2 & 0 & 4,2 & 43,6 & 100 \\
\hline 9 & Lož in Stari trg pri L. & 5884 & 245 & 444 & 3350 & 9923 & 59,3 & 2,5 & 4,5 & 33,8 & 100 \\
\hline 10 & Parecag & 5342 & 0 & 2603 & 1596 & 9541 & 56 & 0 & 27,3 & 16,7 & 100 \\
\hline 11 & Križ in Šepulje & 29887 & 0 & 1602 & 6752 & 38241 & 78,2 & 0 & 4,2 & 17,7 & 100 \\
\hline$\sum$ & skupaj & 157107 & 2161 & 14692 & 45904 & 219864 & 71,5 & 1 & 6,7 & 20,9 & 100 \\
\hline
\end{tabular}


Preglednica 11: Indeks spremembe površine posameznih tipov pozidanih površin v obdobju 2005/1992 po naseljih.

\begin{tabular}{|c|c|c|c|c|c|c|}
\hline & ime naselja & $\begin{array}{l}\text { stanov. indiv. } \\
\text { gradnja }\end{array}$ & $\begin{array}{l}\text { stanov. blok. } \\
\text { gradnja }\end{array}$ & $\begin{array}{l}\text { mešano stanov.- } \\
\text { nestanovanjska }\end{array}$ & nestanovanjska gr. & skupaj \\
\hline$A$ & \multicolumn{6}{|c|}{ STRNJENO OBMOČJE NASELJA } \\
\hline 1 & Spodnja in Zgornja Besnica & 103,24 & - & 104,23 & 109,93 & 103,55 \\
\hline 2 & Ihan & 106,57 & 266,61 & 111,74 & 100,4 & 103,9 \\
\hline 3 & Brdinje & 102,8 & - & 100,97 & - & 102,48 \\
\hline 4 & Lipovci & 105,09 & - & 100 & 112,56 & 106,07 \\
\hline 5 & Krčevina pri Vurbergu & 102,38 & - & - & - & 102,38 \\
\hline 6 & Uršna Sela & 107,38 & - & 105,06 & 107,09 & 107,27 \\
\hline 7 & Žužemberk & 105,43 & 100 & 106,86 & 115,11 & 106,72 \\
\hline 8 & Velike Lašče & 112,52 & 100 & 103,56 & 117,31 & 112,66 \\
\hline 9 & Lož in Stari trg pri L. & 103,15 & 102,64 & 102,24 & 101,77 & 102,5 \\
\hline 10 & Parecag & 109,42 & 100 & 112,75 & 107,54 & 108,97 \\
\hline 11 & Križ in Šepulje & 118,25 & - & 111,2 & 170,62 & 120,64 \\
\hline$\sum$ & skupaj & 106,35 & 110,56 & 106 & 106,6 & 106,41 \\
\hline$A$ & \multicolumn{6}{|c|}{ NESTRNJENO OBMOČJE NASELJA } \\
\hline 1 & Spodnja in Zgornja Besnica & 112,95 & - & 130,94 & 105,04 & 111,96 \\
\hline 2 & Ihan & 110,86 & - & 100 & 134,19 & 122,52 \\
\hline 3 & Brdinje & 125,71 & - & 109,38 & 300,46 & 125,31 \\
\hline 4 & Lipovci & 100,27 & - & 100 & 119,53 & 117,21 \\
\hline 5 & Krčevina pri Vurbergu & 113,37 & - & 119,11 & 105,55 & 113,12 \\
\hline 6 & Uršna Sela & 110,45 & 100 & 131,79 & 101,97 & 109,8 \\
\hline 7 & Žužemberk & 105,98 & - & 100 & 109,56 & 106,38 \\
\hline 8 & Velike Lašče & 118,93 & - & 119,21 & 128,56 & 122,76 \\
\hline 9 & Lož in Stari trg pri L. & 102,65 & - & 100 & 101,4 & 101,56 \\
\hline 10 & Parecag & 105,62 & 100 & 106,92 & 100 & 105,2 \\
\hline 11 & Križ in Šepulje & 149,69 & - & 100 & 103,16 & 127,5 \\
\hline$\sum$ & skupaj & 113,65 & 100 & 114,12 & 109,05 & 112,53 \\
\hline $\bar{A}$ & \multicolumn{6}{|c|}{ VSE POSELJENO OBMOČJE NASELJA } \\
\hline 1 & Spodnja in Zgornja Besnica & 105,14 & - & 108,3 & 106,92 & 105,45 \\
\hline 2 & Ihan & 107,15 & 266,61 & 111,41 & 102,93 & 105,58 \\
\hline 3 & Brdinje & 116,18 & - & 104,65 & 300,46 & 115,5 \\
\hline 4 & Lipovci & 105,06 & - & 100 & 114,77 & 106,95 \\
\hline 5 & Krčevina pri Vurbergu & 112,73 & - & 119,11 & 105,55 & 112,56 \\
\hline 6 & Uršna Sela & 108,96 & 100 & 119,76 & 102,71 & 108,68 \\
\hline 7 & Žužemberk & 105,5 & 100 & 105,95 & 113,84 & 106,67 \\
\hline 8 & Velike Lašče & 113,51 & 100 & 105,66 & 119,62 & 114,34 \\
\hline 9 & Lož in Stari trg pri L. & 103,12 & 102,64 & 102,12 & 101,66 & 102,34 \\
\hline 10 & Parecag & 106,74 & 100 & 110,47 & 105,62 & 106,96 \\
\hline 11 & Križ in Šepulje & 120,53 & - & 110,51 & 138,04 & 121,41 \\
\hline$\Sigma$ & skupaj & 108,5 & 110,02 & 107,92 & 107,32 & 108,18 \\
\hline
\end{tabular}

Naselja lahko glede strukture novih pozidanih površin in glede razlik med strnjeno in nestrnjeno poseljenim delom naselja razvrstimo v nekaj ne izrazito ločenih skupin (slike 21-23):

- Lož-Stari trg, Ihan in Lipovci (delež stanovanjske gradnje od novogradnje je pod $65 \%$, visok je delež nestanovanjskih novogradenj v nestrnjenem delu naselja, to je pri večjih proizvodnih objektih na obrobju naselja);

- Žužemberk in Velike Lašče (delež stanovanjske gradnje od novogradnje je pod 65 \%, visok je delež nestanovanjskih novogradenj v strnjenem delu naselja);

- Parecag (delež stanovanjske novogradnje je pod $65 \%$, visok je delež mešane gradnje, tako v strnjenem kot nestrnjenem delu naselja);

- Spodnja in Zgornja Besnica, Brdinje, Krčevina pri Vurbergu, Uršna sela (delež stanovanjske gradnje od novogradnje je nad $80 \%$ ter prevladuje v strnjenem in nestrnjenem delu naselja; deleža mešane in nestanovanjske gradnje sta po obsegu izenačena);

- Križ-Šepulje (naselje z najbolj intenzivno novogradnjo od vseh obravnavanih, prevladuje stanovanjska novogradnja). 
Preglednica 12: Srednja letna stopnja rasti posameznih tipov pozidanih površin po naseljih (v \%) za obdobje 1992/2005 in za krajša obdobja.

\begin{tabular}{|c|c|c|c|c|c|c|c|c|c|c|c|c|c|c|c|c|}
\hline \multirow[b]{2}{*}{ A } & \multirow{2}{*}{$\begin{array}{c}\text { ime naselja } \\
\text { STRNJENO } \\
\text { OBMOČJE } \\
\text { NASELJA }\end{array}$} & \multicolumn{3}{|c|}{ stanov. individ. gradnja } & \multicolumn{3}{|c|}{ stanov. blokovna gradnja } & \multicolumn{3}{|c|}{ mešano stanov. in dejavnosti } & \multicolumn{3}{|c|}{ dejavnosti } & \multicolumn{3}{|c|}{ skupaj } \\
\hline & & $\begin{array}{c}1992 / \\
1998 \\
\%\end{array}$ & $\begin{array}{c}1999 / \\
2005 \\
\%\end{array}$ & $\begin{array}{c}1992 / \\
2005 \\
\%\end{array}$ & $\begin{array}{c}1992 / \\
1998 \\
\%\end{array}$ & $\begin{array}{c}1999 / \\
2005 \\
\%\end{array}$ & $\begin{array}{c}1992 / \\
2005 \\
\%\end{array}$ & $\begin{array}{c}1992 / \\
1998 \\
\%\end{array}$ & $\begin{array}{c}1999 / \\
2005 \\
\%\end{array}$ & $\begin{array}{c}1992 / \\
2005 \\
\%\end{array}$ & $\begin{array}{c}1992 / \\
1998 \\
\% \\
\end{array}$ & $\begin{array}{c}1999 / \\
2005 \\
\%\end{array}$ & $\begin{array}{c}1992 / \\
2005 \\
\%\end{array}$ & $\begin{array}{c}1992 / \\
1998 \\
\%\end{array}$ & $\begin{array}{c}1999 / \\
2005 \\
\%\end{array}$ & $\begin{array}{c}1992 / \\
2005 \\
\%\end{array}$ \\
\hline 1 & $\begin{array}{l}\text { Spodnja in Zgornja } \\
\text { Besnica }\end{array}$ & 0,36 & 0,17 & 0,25 & - & - & - & 0,83 & 0 & 0,32 & 1,15 & 0,47 & 0,73 & 0,42 & 0,17 & 0,27 \\
\hline 2 & Ihan & 0,93 & 0,12 & 0,49 & 17,75 & 0 & 7,83 & 1,87 & 0 & 0,86 & 0,07 & 0 & 0,03 & 0,6 & 0,04 & 0,29 \\
\hline 3 & Brdinje & 0,24 & 0 & 0,18 & - & - & - & 0,08 & 0 & 0,06 & - & - & - & 0,21 & 0 & 0,16 \\
\hline 4 & Lipovci & 0,25 & 0,46 & 0,33 & - & - & - & 0 & 0 & 0 & 0,29 & 1,55 & 0,79 & 0,24 & 0,62 & 0,39 \\
\hline 5 & Krčevina pri Vurbergu & 0 & 0,29 & 0,18 & - & - & - & - & - & - & - & - & - & 0 & 0,29 & 0,18 \\
\hline 6 & Uršna Sela & 0,75 & 0,23 & 0,55 & - & - & - & 0 & 0,99 & 0,38 & 0,86 & 0 & 0,53 & 0,72 & 0,26 & 0,54 \\
\hline 7 & Žužemberk & 0,54 & 0,32 & 0,41 & 0 & 0 & 0 & 1,34 & 0 & 0,51 & 0,87 & 1,23 & 1,09 & 0,64 & 0,42 & 0,5 \\
\hline 8 & Velike Lašče & 1,87 & 0,1 & 0,91 & 0 & 0 & 0 & 0,59 & 0 & 0,27 & 0,57 & 1,81 & 1,24 & 1,3 & 0,6 & 0,92 \\
\hline 9 & Lož in Stari trg pri L. & 0,47 & 0,09 & 0,24 & 0,52 & 0 & 0,2 & 0,44 & 0 & 0,17 & 0,35 & 0 & 0,14 & 0,42 & 0,05 & 0,19 \\
\hline 10 & Parecag & 1,49 & 0,2 & 0,69 & 0 & 0 & 0 & 1,84 & 0,36 & 0,93 & 1,46 & 0 & 0,56 & 1,47 & 0,16 & 0,66 \\
\hline 11 & Križ in Šepulje & 2,62 & 0,16 & 1,2 & - & - & - & 1,79 & 0 & 0,76 & 9,31 & 0 & 3,89 & 3 & 0,13 & 1,35 \\
\hline$\Sigma$ & skupaj & 0,76 & 0,23 & 0,47 & 1,69 & 0 & 0,78 & 0,9 & 0,06 & 0,45 & 0,59 & 0,41 & 0,49 & 0,74 & 0,26 & 0,48 \\
\hline$B$ & $\begin{array}{l}\text { NESTRNJENO } \\
\text { OBMOČJJ } \\
\text { NASELJA }\end{array}$ & $\begin{array}{c}1992 / \\
1998 \\
\%\end{array}$ & $\begin{array}{c}1999 / \\
2005 \\
\%\end{array}$ & $\begin{array}{c}1992 / \\
2005 \\
\%\end{array}$ & $\begin{array}{c}1992 / \\
1998 \\
\% \\
\end{array}$ & $\begin{array}{c}1999 / \\
2005 \\
\%\end{array}$ & $\begin{array}{c}1992 / \\
2005 \\
\%\end{array}$ & $\begin{array}{c}1992 / \\
1998 \\
\% \\
\end{array}$ & $\begin{array}{c}1999 / \\
2005 \\
\%\end{array}$ & $\begin{array}{c}1992 / \\
2005 \\
\%\end{array}$ & $\begin{array}{c}1992 / \\
1998 \\
\% \\
\end{array}$ & $\begin{array}{c}1999 / \\
2005 \\
\%\end{array}$ & $\begin{array}{c}1992 / \\
2005 \\
\%\end{array}$ & $\begin{array}{c}1992 / \\
1998 \\
\% \\
\end{array}$ & $\begin{array}{c}1999 / \\
2005 \\
\%\end{array}$ & $\begin{array}{c}1992 / \\
2005 \\
\%\end{array}$ \\
\hline 1 & $\begin{array}{l}\text { Spodnja in Zgornja } \\
\text { Besnica }\end{array}$ & 1,17 & 0,8 & 0,94 & - & - & - & 5,54 & 0 & 2,1 & 0,99 & 0 & 0,38 & 1,31 & 0,6 & 0,87 \\
\hline 2 & Ihan & 0 & 1,48 & 0,8 & - & - & - & 0 & 0 & $\overrightarrow{0}$ & 0 & 4,29 & 2,29 & 0 & 2,94 & 1,57 \\
\hline 3 & Brdinje & 1,94 & 0,23 & 1,54 & - & - & - & 0,78 & 0 & 0,6 & 10,04 & 0 & 7,61 & 1,92 & 0,2 & 1,52 \\
\hline 4 & Lipovci & 0 & 0,05 & 0,02 & - & - & - & 0 & 0 & 0 & 0,61 & 2,08 & 1,2 & 0,54 & 1,85 & 1,06 \\
\hline 5 & Krčevina pri Vurbergu & 2,29 & 0,15 & 0,97 & - & - & - & 2,24 & 0,81 & 1,35 & 0,68 & 0,25 & 0,42 & 2,19 & 0,19 & 0,95 \\
\hline 6 & Uršna Sela & 1,04 & 0,33 & 0,77 & 0 & 0 & 0 & 1,03 & 3,95 & 2,15 & 0,24 & 0 & 0,15 & 0,9 & 0,44 & 0,72 \\
\hline 7 & Žužemberk & 0,53 & 0,4 & 0,45 & - & - & - & 0 & 0 & 0 & 0 & 1,15 & 0,7 & 0,37 & 0,54 & 0,48 \\
\hline 8 & Velike Lašče & 2,55 & 0,32 & 1,34 & - & - & - & 2,97 & 0 & 1,36 & 4,28 & 0 & 1,95 & 3,29 & 0,16 & 1,59 \\
\hline 9 & Lož in Stari trg pri L. & 0,52 & 0 & 0,2 & - & - & - & 0 & 0 & 0 & 0,28 & 0 & 0,11 & 0,31 & 0 & 0,12 \\
\hline 10 & Parecag & 0,65 & 0,28 & 0,42 & 0 & 0 & 0 & 1,35 & 0 & 0,52 & 0 & 0 & 0 & 0,67 & 0,21 & 0,39 \\
\hline 11 & Križ in Šepulje & 6,29 & 0,47 & 2,92 & - & - & - & 0 & 0 & 0 & 0,52 & 0 & 0,22 & 3,73 & 0,29 & 1,75 \\
\hline$\Sigma$ & skupaj & 1,78 & 0,32 & 0,99 & 0 & 0 & 0 & 1,58 & 0,54 & 1,02 & 0,71 & 0,64 & 0,67 & 1,51 & 0,4 & 0,91 \\
\hline
\end{tabular}




\begin{tabular}{|c|c|c|c|c|c|c|c|c|c|c|c|c|c|c|c|c|}
\hline \multirow[b]{2}{*}{ C } & \multirow{2}{*}{$\begin{array}{l}\text { ime naselja } \\
\text { VSE POŠLJJENO } \\
\text { OBMOČJE } \\
\text { NASELJA }\end{array}$} & \multicolumn{3}{|c|}{ stanov. individ. gradnja } & \multicolumn{3}{|c|}{ stanov. blokovna gradnja } & \multicolumn{3}{|c|}{ mešano stanov. in dejavnosti } & \multicolumn{3}{|c|}{ dejavnosti } & \multicolumn{3}{|c|}{ skupaj } \\
\hline & & $\begin{array}{c}1992 / \\
1998 \\
\%\end{array}$ & $\begin{array}{c}1999 / \\
2005 \\
\%\end{array}$ & $\begin{array}{c}1992 / \\
2005 \\
\%\end{array}$ & $\begin{array}{c}1992 / \\
1998 \\
\% \\
\end{array}$ & $\begin{array}{c}1999 / \\
2005 \\
\%\end{array}$ & $\begin{array}{c}1992 / \\
2005 \\
\%\end{array}$ & $\begin{array}{c}1992 / \\
1998 \\
\%\end{array}$ & $\begin{array}{c}1999 / \\
2005 \\
\%\end{array}$ & $\begin{array}{c}1992 / \\
2005 \\
\%\end{array}$ & $\begin{array}{c}1992 / \\
1998 \\
\% \\
\end{array}$ & $\begin{array}{c}1999 / \\
2005 \\
\%\end{array}$ & $\begin{array}{c}1992 / \\
2005 \\
\%\end{array}$ & $\begin{array}{c}1992 / \\
1998 \\
\% \\
\end{array}$ & $\begin{array}{c}1999 / \\
2005 \\
\%\end{array}$ & $\begin{array}{c}1992 / \\
2005 \\
\%\end{array}$ \\
\hline 1 & $\begin{array}{l}\text { Spodnja in Zgornja } \\
\text { Besnica }\end{array}$ & 0,52 & 0,3 & 0,39 & - & - & - & 1,61 & 0 & 0,62 & 1,05 & 0,18 & 0,52 & 0,63 & 0,27 & 0,41 \\
\hline 2 & Ihan & 0,81 & 0,3 & 0,53 & 17,75 & 0 & 7,83 & 1,82 & 0 & 0,83 & 0,06 & 0,36 & 0,22 & 0,54 & 0,31 & 0,42 \\
\hline 3 & Brdinje & 1,27 & 0,14 & 1,01 & - & - & - & 0,4 & 0 & 0,3 & 10,04 & 0 & 7,61 & 1,22 & 0,12 & 0,97 \\
\hline 4 & Lipovci & 0,25 & 0,46 & 0,33 & - & - & - & 0 & 0 & 0 & 0,39 & 1,72 & 0,92 & 0,27 & 0,72 & 0,45 \\
\hline 5 & Krčevina pri Vurbergu & 2,17 & 0,16 & 0,93 & - & - & - & 2,24 & 0,81 & 1,35 & 0,68 & 0,25 & 0,42 & 2,08 & 0,19 & 0,91 \\
\hline 6 & Uršna Sela & 0,9 & 0,29 & 0,66 & 0 & 0 & 0 & 0,58 & 2,72 & 1,4 & 0,34 & 0 & 0,21 & 0,82 & 0,36 & 0,64 \\
\hline 7 & Žužemberk & 0,54 & 0,33 & 0,41 & 0 & 0 & 0 & 1,16 & 0 & 0,45 & 0,67 & 1,21 & 1 & 0,6 & 0,43 & 0,5 \\
\hline 8 & Velike Lašče & 1,97 & 0,14 & 0,98 & 0 & 0 & 0 & 0,92 & 0 & 0,42 & 1,39 & 1,39 & 1,39 & 1,64 & 0,52 & 1,04 \\
\hline 9 & Lož in Stari trg pri L. & 0,48 & 0,09 & 0,24 & 0,52 & 0 & 0,2 & 0,42 & 0 & 0,16 & 0,33 & 0 & 0,13 & 0,4 & 0,04 & 0,18 \\
\hline 10 & Parecag & 0,9 & 0,26 & 0,5 & 0 & 0 & 0 & 1,65 & 0,22 & 0,77 & 1,1 & 0 & 0,42 & 1,05 & 0,19 & 0,52 \\
\hline 11 & Križ in Šepulje & 2,91 & 0,18 & 1,34 & - & - & - & 1,68 & 0 & 0,72 & 5,52 & 0 & 2,33 & 3,08 & 0,15 & 1,4 \\
\hline$\Sigma$ & skupaj & 1,06 & 0,26 & 0,63 & 1,6 & 0 & 0,74 & 1,06 & 0,18 & 0,59 & 0,62 & 0,48 & 0,55 & 0,96 & 0,3 & 0,61 \\
\hline
\end{tabular}


Slika 24: Indeks rasti pozidanih površin za obdobje 2005/1992 po tipu poselitve in naseljih.

Glej angleški del prispevka.

Večji del novo pozidanih površin (56\%) je sicer še vedno v strnjenih jedrih naselij, dinamika relativne rasti pozidave pa je večja na obrobju naselja, kjer so se pozidane površine v obdobju 1992-2005 povečale za 12,5\%, v naseljskih središčih pa le za 6,4\% (slika 24). Trend je značilen za večino obravnavanih naselij. V primeru Loža-Starega trga in Žužemberka vlogo obrobja prevzemajo sosednja manjša naselja (elementi suburbanizacije na lokalnem nivoju). Parecag je sicer razloženo naselje, a ga podobno kot veliko drugih podeželskih naselij Slovenske Istre sestavlja več zaselkov, ki prevzemajo vlogo znotraj naseljskih zgostitev, $v$ katerih poteka večina novogradnje. Krepitev gradnje na obrobju naselja oziroma v coni nestrnjene poselitve je značilna za vse vrste pozidave (slika 25), najbolj za stanovanjsko in mešano gradnjo.

Slika 25: Povprečni indeks rasti pozidanih površin posamezne vrste po tipu poselitve (2005/1992).

Glej angleški del prispevka.

Dinamika gradnje v celotnem obravnavanem obdobju ni bila enakomerna. Novogradnja je bila pogostejša v zgodnjih in srednjih devetdesetih letih, v drugi polovici obdobja pa je močno upadla (preglednica 12). Intenzivnost novogradnje se je v drugi polovici znižala za več kot trikrat (srednja letna stopnja rasti pozidanih površin je bila v prvem obdobju $1 \%$, v drugem pa $0,3 \%$ ), stanovanjske gradnje za štirikrat in mešane za šestkrat. Manjši padec beleži samo nestanovanjska gradnja, ki se je v primerjavi s prvo polovico obdobja zmanjšala le za $23 \%$. Trend je značilen za vsa naselja (slika 26), izjema so le Lipovci, kjer se je intenzivnost gradnje v celoti povečala, predvsem na račun povečanja nestanovanjskih površin v nestrnjeno poseljenem delu naselja (v industrijskem kompleksu ob železnici).

Slika 26: Srednja letna stopnja rasti pozidanih površin za obdobji 1992/1998 in 1999/2005 po naseljih (leto 1992 = 100).

Glej angleški del prispevka.

\section{Sklep}

Prispevek obravnava značilnosti poselitvene rabe tal v slovenskih podeželskih naseljih ter prostorskih in funkcijskih sprememb v teh naseljih v 15-letnem obdobju od osamosvojitve Slovenije leta 1991 dalje. Podlage so letalski posnetki za leto 1991, ortofotografski posnetki za leto 2002 in terensko kartiranje za leto 2005. Kvantitativne spremembe smo ugotavljali na primeru 11 poselitvenih enot oziroma 14 naselij, ki zavzemajo 9664,57 ha površin in tvorijo ekspertni, ne pa statistični vzorec. Ta je bil izbran med slovenskimi podeželskimi naselji, ki so v obdobju 1991-2002 izkazovala rast števila prebivalcev in števila hiš, ki so imela leta 2002 med 500 in 1100 prebivalcev, relativno velik delež kmečkih prebivalcev in prisotne posamezne središčne funkcije. Zastopani so različni morfološki tipi naselij ter različne slovenske naravne in statistične regije.

V okviru posameznega naselja nas je zanimalo le poseljeno območje oziroma območje, kjer obstajajo pozidane površine; izločili smo strnjene kmetijske in gozdne površine in prometnice znotraj teh. V povprečju je znotraj obravnavanih naselij 23,5 \% poseljenih površin. Poleg površin, ki jih pokrivajo različni objekti, spada sem še 100 -metrski pas zemljišča okrog njih.

Razlikovali smo strnjeno in nestrnjeno poseljeno območje - prvo zavzema četrtino, drugo pa tri četrtine poseljenih površin. Struktura obeh območij se precej razlikuje in je odvisna od reliefa in vodnih razmer oziroma od morfološkega tipa naselja. V strnjeno poseljenem območju pozidane površine zavzemajo povprečno $36 \%$ površin, prometne $9 \%$, drobne zelene in kmetijske površine $47 \%$ in drobne gozdne površine $8 \%$, v nestrnjeno poseljenem območju pa je pozidanih površin $5 \%$, prometnih $4 \%$, zelenih in kmetijskih $64 \%$ in gozdnih $26 \%$. Na delež prometnih površin poleg naravnih razmer in posestne strukture vpliva tudi razporeditev državnih oziroma hitrih cest (od tod daleč največji delež prometnih površin v Lipovcih). Športne površine in parki ter vodne površine niso prisotne v vseh naseljih, zavzemajo največ nekaj odstotkov površin in niso povezane s strnjenostjo naselja, ampak s številom in strukturo delovnih mest ter oddaljenostjo od urbanih središč.

Med poseljenimi površinami so največje pozornosti deležne pozidane površine, ki jih je povprečno $13 \%$ (36\% v strnjeno- in $5 \%$ v nestrnjeno poseljenem delu). Pozidane površine v strnjeno poseljenem 
območju pokrivajo predvsem stanovanjski objekti ( $68 \%$ ), $25 \%$ objektov je namenjenih le dejavnostim, $7 \%$ pa jih ima mešano namembnost. V nestrnjeno poseljenem območju razmerja niso bistveno drugačna: $71 \%$ pozidanih površin odpade na stanovanjske objekte, $23 \%$ na dejavnosti in $6 \%$ na objekte z mešano namembnostjo. Med stanovanjskimi površinami le dober odstotek zavzemajo večstanovanjski objekti. Prisotni so le v polovici naselij, število takih objektov pa je povsod nižje od 10.

Ena pomembnih družbenogospodarskih značilnosti vzorca naselij je vožnja večine delovno aktivnih prebivalcev (v povprečju 74 \%) v bližnja zaposlitvena središča. Presežek delovnih mest nad delovno aktivnimi imata le dve od 11 enot. To sta zaposlitveni središči Lož/Stari trg in Žužemberk, ostala naselja so izvorna območja delovno aktivnih prebivalcev.

Po Vrišerjevi klasifikaciji med obravnavanimi naselji štiri nimajo nobene središčne funkcije, štiri imajo najnižjo - prvo stopnjo središčnosti, tri z nekaterimi specializiranimi storitvami pa drugo stopnjo središčnosti.

Znotraj našega vzorca lahko jasno ločimo tri kategorije naselij:

- zaposlitvena središča, ki so odmaknjena od velikih urbanih središč, v katerih se krepijo oskrbne funkcije, suburbanizacija oziroma širitev stanovanjskih površin je manj intenzivna. Podjetja imajo tu večje število zaposlenih.

- naselja, ki imajo poleg delovnih mest $v$ kmetijstvu še manjše število delovnih mest $\mathrm{v}$ posameznih proizvodnih obratih, zraslih $\mathrm{v}$ procesu preteklega policentričnega razvoja, ki so močno vezana na bližnja urbana središča,

- naselja v območju močne suburbanizacije, kjer so redka delovna mesta vezana na kmetije in samostojna podjetja z manj kot štirimi zaposlenimi, velika večina delovno aktivnih pa dnevno migrira v bolj ali manj oddaljena zaposlitvena središča. Stanovanjske površine in površine pripadajoče infrastrukture se tu še naprej širijo.

Namembnost objektov smo določili s pomočjo registra Agencije Republike Slovenije za javnopravne evidence in storitve (AJPES) za leto 2002. S terenskim delom leta 2005 smo korigirali napake, pa tudi spremembe po letu 2002. Ker se standardni klasifikaciji dejavnosti, ki jih uporablja Statistični urad RS, za leti 1991 in 2002 ne ujemata, smo zaradi primerljivosti morali dejavnosti smiselno združiti. Tako smo dobili sedem kategorij: kmetijske dejavnosti, predelovalne dejavnosti, gradbeništvo, trgovina, gostinstvo in turizem, promet, druge storitvene dejavnosti. Osma kategorija združuje dve ali več različnih dejavnosti.

O značilnostih novogradnje v obravnavanih naseljih v obdobju med letoma 1992 in 2005 lahko sklenemo naslednje:

- večino novogradenj (okrog $70 \%$ ) predstavlja stanovanjska gradnja, okrog $20 \%$ nestanovanjska in okrog $10 \%$ mešana stanovanjsko-nestanovanjska;

- novogradnja je bila najintenzivnejša na območjih mlade suburbanizacije, manj pa v naseljih, ki so se suburbanizirala že pred letom 1990 in v večjih središčnih naseljih;

- rast števila novogradenj je bila $\mathrm{v}$ splošnem večja $\mathrm{v}$ razpršenih kot $\mathrm{v}$ gručastih in obcestnih naseljih;

- v nestrnjeno poseljenih delih naselij izrazito prevladujeta stanovanjska in mešana gradnja, $\mathrm{v}$ strnjeno poseljenih pa je nekoliko višji (okrog četrtine) tudi delež nestanovanjske gradnje;

- za vse tipe gradnje velja, da je relativna rast površin višja v nestrnjeno kot $\mathrm{v}$ strnjeno poseljenih delih naselij;

- dinamika novogradnje je $\mathrm{v}$ drugi polovici obravnavanega obdobja močno upadla, to še posebej velja za stanovanjsko in mešano gradnjo in nekoliko manj za nestanovanjsko;

- rast nestanovanjskih površin je pogosto povezana z novimi objekti v okviru enega samega ali dveh gospodarskih podjetij;

- obseg novogradnje ni premosorazmeren velikosti naselja, pač pa s priseljevanjem v naselje.

\section{Viri in literatura}

Glej angleški del prispevka. 